\title{
Las últimas visitas del priorato de San Salvador de Chantada (Lugo) por los abades de Valladolid: edición y estudio
}

Xosé Méndez Pérez ${ }^{1}$

Recibido: 14 de xullo de 2016 / Aceptado: 17 de outubro de 2016

Resumen. En este trabajo estudiamos, partiendo de la crisis generalizada de los siglos XIV y XV, el contexto de la reforma emprendida por San Benito el Real de Valladolid y la consiguiente dependencia de todos los monasterios reformados a esta casa. En concreto, se estudiaron cuatro visitas monásticas de los últimos años del priorato de San Salvador de Chantada (Lugo) antes de la Desamortización, de las que ofrecemos transcripción en apéndice.

Palabras clave: Visitas monásticas; Edad Media y Moderna; San Benito el Real de Valladolid; San Salvador de Chantada.

\section{[gl] As últimas visitas do priorado de San Salvador de Chantada (Lugo) polos abades de Valladolid: edición e estudio}

Resumo. Neste traballo estudamos, partindo da crise xeneralizada dos séculos XIV e XV, o contexto da reforma emprendida por San Benito el Real de Valladolid e a consecuente dependencia de todos os mosteiros reformados a esta casa. Nomeadamente, centrámonos en catro visitas monásticas dos últimos anos do priorado de San Salvador de Chantada (Lugo) antes da Desamortización, das que ofrecemos transcrición en apéndice.

Palabras chave: Visitas monásticas; Idade Media e Moderna; San Benito el Real de Valladolid; San Salvador de Chantada.

\section{[en] The Last Visits of the Abbots of Valladolid to the Priory of San Salvador de Chantada (Lugo): Edition and Study}

Abstract. Bearing in mind the general crisis of the $14^{\text {th }}$ and $15^{\text {th }}$ centuries, this work studies the impact of the reformation initiated by San Benito el Real de Valladolid and the consequent dependence of all the reformed monasteries to this house. In this work we shall concentrate on four monastic visits in the last years of the Priory of San Salvador de Chantada, Lugo, before the Ecclesiastical Confiscations took place. Transcriptions of these visits can be found in the appendix.

Keywords: Monastic Visits; Middle Ages; Modern Ages; San Benito el Real de Valladolid; San Salvador de Chantada.

Sumario. 1. Introducción. 2. La reforma. 2.1. El contexto general: claves de comprensión. 2.2. El contexto social gallego: apuntes generales. 3. La fundación de San Benito el Real de Valladolid. 3.1. La anexión de monasterios a Valladolid. 3.2. Las dificultades de la reforma. 3.3. La anexión de Chantada. 4. Texto de las visitas conservadas y conocidas de Chantada. 5. Colofón. 6. Referencias bibliográficas.

Como citar: Méndez Pérez, X. (2016): "Las últimas visitas del priorato de San Salvador de Chantada (Lugo) por los abades de Valladolid: edición y estudio", en Madrygal. Revista de Estudios Gallegos 19, 113-149. 


\section{Introducción}

A la hora de presentar las "visitas" de los últimos años de vida del monasterio de San Salvador de Asma (Chantada, Lugo), es necesario situarlas dentro de las circunstancias en que nació esta tipología documental. Por eso, vamos a esbozar dos cuestiones que nos darán la clave para situarlas y entenderlas en su contexto. Primeramente, nos referiremos a las circunstancias generales de clamor y exigencia demandando la reforma en todos los estamentos tanto civiles como eclesiásticos en los siglos XIV y, en especial, en el XV. Por otro lado, daremos unas pinceladas sobre el contexto gallego en ese momento.

Una vez situados en el contexto general de la reforma abordaremos, en un segundo momento, la fundación del Real monasterio de San Benito de Valladolid para que podamos interpretar la dependencia que tendrán de él los prioratos reformados y la presión que éste ejercerá sobre ellos. De este modo, podremos entender en su situación vital las "visitas" monásticas del abad de Valladolid al priorato de Chantada, donde con nitidez se palpa esa dependencia y la presión que ejerce en las distintas dimensiones de la vida del priorato un conjunto de "amenazas veladas" y cargadas con toda clase de penas que aparecen en sus Constituciones.

\section{La reforma}

\subsection{El contexto general: claves de compren- sión}

Para comprender la anexión del monasterio de Chantada a Valladolid, son necesarias unas mínimas coordenadas previas a su fundación, aunque aquí no podamos hacer más que señalarlas.

Comenzaremos afirmando -así lo confirman todas las fuentes del momento- que nunca en la Iglesia hubo tanta exigencia y clamor por la reforma como en los siglos XIV y XV. La reforma es una obsesión universal que cunde sus raíces en las más plurales clases sociales con un tinte un tanto mesiánico, revistiendo en casos un carácter revolucionario.

Los predicadores populares a través del devoto "exemplum" y moralización, dejando la predicación anónima de siglos pasados, llevan al púlpito a los nobles, burgueses, clérigos, villanos..., pretendiendo con estilo fogoso, popular, tremendista, apocalíptico, anatematizante e irónico provocar una reforma llevando a la conversión.

Los escritores, entre los que podemos recordar al Arcipreste de Hita en su Libro de buen amor, usando los exempla para moralizar; o a Pedro López de Ayala y su Rimado de Palacio donde, haciéndo a menudo una lectura moral de una realidad desordenada, llena de abusos de poder, soberbia y viendo el mundo "en quexa y en tribulación", achaca esta situación al mal actuar del rey, los señores, los clérigos, los letrados. Y así describe, aunque no completamente, una sociedad que está pasando una crisis política, religiosa, económica y social. Por eso, dentro de la sociedad organicista y conservadora en que se mueve, y sin ofrecer más soluciones que su crítica, el bien vendrá cuando cada uno actúe conforme a sus deberes.

Los gobernantes, de los distintos rangos, pues entre ellos y por todas partes estaban presentes, en mayor o menor grado, la inquietud social, las intrigas cortesanas, los clanes de los linajes, familias provenientes de la hidalguía enfrentadas con grandes enemistades, el bandolerismo de los pueblos, las represalias de los nobles contra las villas y el consiguiente desenfreno moral; en tales estamentos tales hechos se propagaban de una manera alarmante. Existía, además, el peligro de las disensiones religiosas fomentado por los falsos conversos, judíos y mahometanos, como veremos más adelante.

Los eclesiásticos de todos los estamentos levantan de mil formas la voz en lo que llamamos otoño de la Edad Media ${ }^{2}$, clamando por la 
reforma ${ }^{3}$ "in capite et in membris" de una iglesia decadente en su moralidad ${ }^{5}$. De ahí que en el concilio de Constanza (con toda la turbulencia de tres papas: Juan XXIII, Gregorio XII y Benedicto XIII), bajo Martín V presentara unos decretos de reforma eclesiástica (Domenico Mansi 1961: 27, 1174-1176).

Todo este contexto nos está indicando que en cualquiera de los estamentos, tanto religiosos como civiles, era necesaria una reforma radical. Llama la atención la vida monacal gallega a tenor de lo que conocemos de procesos incoados contra priores y abades en el momento de la reforma ${ }^{6}$. Los documentos de la época dejan entrever una lamentable moralidad en todos los estamentos clericales. Y en este sentido moral no es cuestión de desentenderse y olvidar los datos históricos que encontramos en las fuentes, arguyendo que en España no se daba lo que en Italia, Alemania o Francia, pues aquí se vivían otras circunstancias cargadas de inmoralidad y grandes sombras. Algunos autores llegan a afirmar que "nunca en toda la historia el mundo monástico había estado, en su conjunto, tan profundamente tocado por la concepción materialista de la vida y por la ausencia de sus ideales como en los siglos XIII y XIV" (Álvarez Gómez 1989: II, 43877). Hay dos cuestiones que abiertamente llevan a esta situación en medio de los enredos administrativos y jurídicos que avienen con el Cisma de Occidente. Por una parte, los monasterios y, en concreto, los benedictinos de la baja Edad Media representaban un cierto atractivo de seguridad y categoría para los hijos de la baja nobleza o de la burguesía, pero no respondían a una vida de satisfacción o rectitud espiritual (cf. Lawrence 1999: 325). Por otra parte, entre otras muchas causas que originaron el decaimiento de las instituciones religiosas, está una que es clave, en el sentido que estamos hablando, como es la encomienda favorecida por los papas de Aviñón por motivos de fiscalidad ${ }^{8}$.

Otro de los datos que también debe valorarse es lo que supuso el "exilio de Aviñón" para el pueblo cristiano, durante 70 años, por la gran desorientación de una potente corte papal tutelada por los reyes franceses, siendo, como acabamos de indicar, una gran potencia económica, un centro ordenador y distribuidor de capitales, pero lejos de la orientación y organización que correspondía ejercer al Papado9.

Otras claves para la comprensión de la vida religiosa del siglo XIV, que desembocará en el XV y culminará en el XVI con una acumulación de reformas, son que la Europa cristiana se encuentra en esos momentos sufriendo una profunda depresión que los historiadores califican, de modo general, como "tiempo de crisis" (cf. Bois 2007, Seibt y Heberhard 1993). Ciertamente, hay una evidente crisis económica, especialmente en la agricultura, que lleva a problemas sociales a los diversos países. Esta crisis, con amplios trastornos económicos, lleva al hambre que se extiende por muchas regiones de Europa y, con ello, una gran baja demográfica. A esta situación se añade la aparición de la peste negra, que acabó en Europa con más de las dos

No es momento para que abundemos en toda esta temática, por eso remitimos a uno de los autores que nos inicia en la situación de la que venimos hablando (García Villoslada 1967: III, 342-658). Mancio de Torres, al comienzo de su Historia de San Benito el Real de Valladolid, dice lo siguiente: "quan acabadas estaban las religiones en Españapor causa de las guerras y por haberse metido muchos no religiosos a impetrar las Abadías y prioratos y por las tiranías de los comenderos y también los monasterios cluniacenses padecían la misma ruina por descuido de los prelados que, aunque solían visitarles cados años ya no acudían por causa de las guerras" (Biblioteca Universitaria de Santa Cruz de Valladolid, Ms. 195, fol. 1).

4 Esta expresión aparece a finales del siglo XIII en los escritos de Roberto de Uzés (cf. Mitre Fernández 2007: 131, n. 57).

5 Baró i Queralt y Ontalba y Ruipérez 1999: 655-667. Sin duda alguna, cabe extrapolar la imagen que encontramos reflejada en este artículo a toda la sociedad europea. En él se afirma: "nos muestra un panorama más bien desolador en lo que se refiere a la moral" (ibid. 667) y, haciendo referencia a algunos de los problemas, se indica que esa situación atañe tanto a los seglares como a los clérigos.

6 Entre los más conocidos cabe recordar los procesos de los prioratos de Pesqueiras (de este monasterio es impresionante el proceso contra la priora conservado entre los papeles de Valladolid que recientemente hemos tenido la ocasión de manejar), Lobios, Lobás, Dozón o Ansemil (para estos tres últimos cf. Zaragoza Pascual 1993: 395-433 y 2002: 81-124).

Citando al autor fracés Ursmer Berlière 1927: 63.

8 Cf. Álvarez Gómez 1989: II, 437. Aquí se nos dice que ha sido modificada por la reforma tridentina; no obstante, que perduró hasta el siglo XX (ibid. 338). Para lo que supuso la residencia del papado en Aviñón vid. cf. Kasper et al (eds.) 2003: 31-33 y 2005: 512-515.

9 Algún autor, reeditado recientemente, nos dice respecto al aparato administrativo que "fue suficientemente sólido como para sobrevivir al cisma de 1378 y permitir a los pontifices rivales - cada uno en su obediencia- mantener su autoridad durante más de cuarenta años, antes de tener que inclinarse ante el Concilio General" (cf. J. Verger 2001²: 125). 
terceras partes de la población. Así, la peste será vista con un simbolismo apocalíptico que repercute de inmediato en muchas dimensiones de la vida, justificaciones existenciales y responsabilidades ${ }^{10}$. A esta crisis se añaden las numerosas luchas sociales y la generalización de la guerra ${ }^{11}$. Se puede afirmar, entonces, que es una época de crisis $^{12}$ que afecta a todos los ámbitos de la vida del occidente medieval.

La crisis religiosa se agudiza con todo el peso del Cisma de Occidente y al tiempo va a influir en todo cuanto está sucediendo en la politica castellana (Álvarez Palenzuela 1982, Kasper et al., eds., 2005a: I, 258-266). En Castilla en el terreno político se está dando todo lo que venimos anotando a cerca de la crisis. Frente a Pedro I se alza su hermano Enrique de Trastámara, amparado por buena parte de la nobleza, y con él se inicia la dinastía Trastámara después de una guerra fratricida (1366-1369) con proyección internacional en la que habían tomado parte los ingleses defendiendo al rey legítimo y los franceses al pretendiente bastardo. Del nuevo rey reciben los poderosos numerosas concesiones y rentas denominadas "mercedes enriqueñas", que Juan I, en las Cortes de Burgos (agosto de 1379), junto con los procuradores y a petición de los condes, caballeros, "ricos homes" y con consejo de los obispos tratan de "que les confirmásemos e guardásemos los ordenamientos e peticiones que fizo e otorgó el rey Alfonso nuestro auuelo y el rey don Enrique nuestro padre nos plaze de se los confirmar" (Colmeiro 1863: II, 287) para recomponer la hacienda, aunque no se lograse, pues el objetivo era otro distinto en la nobleza. Al tiempo, el antisemitismo se usa en el bando trastamarista como un elemento de propaganda que va a quebrar la convivencia entre cristianos y judíos. Las malas relaciones entre el legítimo rey de Castilla y su hermanastro, el futuro Enrique II, van a repercutir en las relaciones entre judíos y cristianos. Así se propagó la idea de que Pedro I favorecía a los judíos en la nueva sinagoga toledana de Samuel Ha-Levi (1357). Parece que la cuestión venía ya de antes, pues las fuerzas de Enrique II atacaron la Alcaná (Barrio judío de Toledo), iniciándose con ello una actitud antijudía que persistiría hasta los Reyes Católicos ${ }^{13}$. Al fallecer Enrique II, en 1379, se corona rey de Castilla y León su hijo Juan I, que tiene que enfrentarse con todo lo que suponía la crisis de sucesión en Portugal en 1383, pues la heredera al trono era su esposa Beatriz. Así, contra su intervencionismo se crea un bloque hostil capitaneado por el maestre de Avis que, ayudado por los ingleses, venció en Aljubarrota (1385) al rey de Castilla. Con este descalabro no se hace esperar un nuevo dolor. Las tropas del duque de Lancaster, que pretendía el trono de Castilla por su esposa, Constanza, hija del destronado Pedro I, invadieron Galicia penetrando hacia tierras leonesas.

Por su parte, Juan I había buscado apoyos para llevar a término lo que, de una u otra forma, estuvo presente es su reinado, la reforma; aspecto este que, aunque no podamos desentrañarlo aquí y conocer con precisión sus concretos objetivos y motivaciones, representa una actuación que se acentúa al final de su vida, pero que siempre había sido una gran preocupación y base de sus decisiones. Quizás donde más se va a dejar notar este aspecto es en las Cortes de Palencia el 4 de octubre de 1388 (Colmeiro 1863: II, 412-424), pues con el concurso del legado de Clemente VII, Pedro de Luna y los prelados del reino debaten la reforma del clero

10 Cf. Mitre Fernández 2004, Ruiz de Loizaga 2009. Para una reciente visión de conjunto sobre el tema vid. Benedictow 2011; véase también Vaca Lorenzo 1990: 159-171, Amasuno Sarraga 1996. Una visión panorámica de la historiografía del tema hasta 1994 puede verse en Beltrán Moya 1994: 283-319.

11 En concreto, la Guerra de los Cien Años o conjunto de conflictos bélicos que, interrumpidos por treguas y tratados de paz, comienzan en 1337 y terminan en 1453 entre las dos potencias del momento: Francia e Inglaterra (vid. Perroy 1982 y Mitre Fernández 1990). Esta guerra mirada desde la "historia de las mentalidades" supuso grandes transformaciones en la vida económica, relaciones políticas y conciencia nacional.

12 Tuchman 2000. En Menéndez Pelayo (1956: 577 y ss.) se describe este siglo con unos rasgos francamente oscuros diciendo entre otras cosas que se caracteriza "por una recrudescencia de barbaria, un como salto atrás en la carrera de la civilización. Las tinieblas palpables del siglo X no infunden más horror ni quizá tanto. Reinan por doquier la crueldad y la lujuria, la sórdida codicia y el anhelo de medros ilicitos; desbocánse todos los apetitos de la carne; el criterio moral se apaga". Remitimos al capítulo IV de esta obra para ver el panorama que refieren los distintos autores.

13 Vid. Valdeón Baruque 1968; para actos violentos contra ellos vid. Mitre Fernández 1994. Estas revueltas llevarán a una dispersión de los judíos, crisis de su fe muy fuerte a finales del siglo XIV y comienzos del XV (Glatzer 1995). Estas persecuciones dieron lugar a numerosas conversiones (Benito Ruano 1976, Amran 1996, 2003). Entre los conversos hay algunos dignos de mención como el que fue obispo de Cartagena (1401) y arzobispo de Burgos (1415), Pablo de Santa María (Serrano y Pineda 1941). Para el tema de la convivencia y relación entre judíos y cristianos véase Mitre Fernández 1980, Monsalvo Antón 1985. 
secular (De correctione et reformatione Ecclesiae), formulando una serie de constituciones ${ }^{14}$, a petición del rey y de varios prelados, como la manera de castigar a los clérigos amancebados, las medidas de la tonsura o el vestido. Se establecen las normas para los clérigos casados y se promulgan también pautas de convivencia para los judíos. Estas constituciones van a imponer una forma de vida al clero secular del reino de Castilla; sin embargo, esta acción de reforma lleva una carga indirecta de reforma del clero regular.

El mal en los reinos españoles venía de muy atrás. Desde la muerte del rey Sabio (1284) los disturbios entre muchos magnates y familias de rango son continuos, llegando en Castilla a la anarquía en el reinado de Enrique IV (1454-1474). Puede decirse que la inquietud social, las intrigas familiares en la corte, los bandos formados por familias nobles enfrentadas, las represalias de muchas de estas familias contra nobles y el desenfreno moral, entre otras circunstancias, queda reflejado en los cronistas con expresiones generales, pero muy duras, al hablar de Castilla:

Llena de mucha soberbia, e de mucha herejía, e de mucha blasfemia, e avaricia, e rapiña, e de muchas guerras, e bandos, e parcialidades, e de muchos ladrones, e salteadores, e rufianes, e matadores, e tahúres, e tableros públicos, que andaban por renta, donde muchas veces el nombre de Nuestro Señor Dios e Nuestra Señora la gloriosa virgen María eran muchas veces blasfemados e renegados de los malos tahúres. (Bernáldez 1870: $25^{15}$ )
En 1469 con el casamiento de la infanta Isabel, hermana de Enrique IV, y del príncipe don Fernando, hijo de Juan II de Aragón, surge un nuevo horizonte. Cinco años más tarde eran reyes de Castilla y en 1449 lo serían de Aragón. Comenzaría, por tanto, una "unificación nacional", pese a que Granada no se conquistase hasta 1492; Navarra se incorporará en 1513. Hemos de notar que esta unificación no es ninguna uniformidad, sino un deseo de paz y reforma de costumbres a todos los niveles y en todos los estamentos de la sociedad ${ }^{16}$.

Los dos concilios -mejor sería llamarlos sínodos, aunque son conocidos como conciliosde Aranda ${ }^{17}$ y Sevilla, presididos por arzobispos españoles en tiempo de estos reyes, secundados y apoyados por ellos, son los primeros pasos de una deseada reforma eclesiástica. El de Aranda marcó un hito en la historia del reformismo de la Iglesia en Castilla ${ }^{18}$; sin embargo, su importancia no radica tanto en este punto, sino en el hecho de que fue, además, un instrumento al servicio de los intereses políticos y religiosos de su mentor, el Arzobispo Carrillo $^{19}$, quien, a su vez, defendía la estrategia de la princesa Isabel, ya que en el sínodo se abordaron asuntos de la Iglesia, pero también hubo un debate político sobre la futura reina de Castilla y sus candentes intereses políticos que la conducirían al trono del mayor reino peninsular. Hay una frase al comienzo mismo del prefacio que expresa bien ese sentido político, al decir que es necesario "promulgar una ley que reprimiera con su virtud las extraviadas

14 El texto puede consultarse en el Archivo Histórico Nacional de Madrid, Dominicos de San Pablo de Burgos, carpeta 186/8.

15 Edición moderna en Gómez Moreno y Carrizo 1962. En la Real Academia de la Historia (2/Ms. 19) hay un ejemplar manuscrito que hemos tenido la suerte de consultar. Cf. Pulgar 1836: vol. XIII, Tomo I, Carta 25, 56-57. Con tintes muy fuertes por su enemistad con Enrique IV, cf. Palencia 1904-08 (ed. Paz y Meliá), Menéndez Pelayo 1944, II, 286-302. Considero que no es menos aleccionadora la sátira de Hernando del Pulgar en las Coplas de Mingo Revulgo y, con un tinte moral muy marcado, en las Coplas del Provincial de Saavedra Fajardo; igualmente en la Dança general de la muerte, donde se retratan agudamente los vicios e intrigas de los eclesiásticos, así como en toda la poesía y obras satíricas de estos siglos.

16 Cf. Suárez Fernández 1981, Tomo V (aunque esta obra debe ser consultada con ojo crítico).

17 Vid. Tejada y Ramiro 1855: 6-29, aunque siempre teniendo en cuenta las características de estos textos para una correcta interpretación.

18 Aunque no podemos pararnos aquí en este aspecto, es necesario advertir que una lectura somera de los textos de este sínodo nos deja ver que el movimiento de reforma había dado, no sólo los primeros pasos, sino que había fermentado y estaba dando sus primeros frutos en unos cánones que marcarán el camino de la reforma posterior del reino de España culminando con la renovación de los Reyes Católicos. Igualmente cabe añadir la apertura a la institución sinodal en las distintas diócesis; cf. la magna obra del Synodicon Hispanum (no nos metemos a valorar la transcripción e interpretaciones en este sentido, aunque las conocemos desde dentro), pues vale como fuente de conocimiento sin igual de esta época.

19 Alfonso Carrillo de Acuña (1410-1482), nombrado obispo de Sigüenza en 1435 y de Toledo en 1446. Señor feudal, con grandes riquezas, permaneció al lado de los Reyes Católicos mientras no vio el momento de ponerse al lado del gran obispo don Pedro González de Mendoza (1428-1495), llamado el “tercer rey de España”, hábil político, hijo del Marqués de Santillana (Iñigo López Mendoza), al cual se enfrentará, pues era hombre de intrigas, que había tenido un hijo natural (don Froilo, al que hará un sepulcro en Alcalá). Arzobispo de Sevilla desde 1474 y primado de Toledo en 1482. 
inclinaciones de los mortales y los dirigiera" y al tiempo "revisar en profundidad muchas actitudes y no pocas costumbres" (Tejada y Ramiro 1855: 6). Alfonso Carrillo de Acuña, en sus últimos años, se centró en el servicio de su diócesis y convocó un concilio que duró dos meses (de enero a marzo de 1473, iniciándose el 5 de diciembre), al que asistieron los obispos de la provincia eclesiástica de Toledo, Burgos y otros, y que se celebró en Aranda de Duero (por obedecer a Isabel y estar dicho lugar defendido por el conde de Benavente, que era tío de Fernando de Aragón ${ }^{20}$ ). Sus cánones son indicativos de esta reforma del clero cuando afirman que: "mejor es en la casa de Dios tener pocos ministros que muchos e indignos" (Tejada y Ramiro 1855: $14^{21}$ ). Es más, van a ser tomados como programa de los sínodos posteriores que, apoyándose en sus propuestas, no harán más que urgir una reforma del clero. Pero en especial este de Aranda, pues sus XXIX cánones están dirigidos a la vida de los clérigos (ibid. 10-1122).
Otro de los concilios que manifiesta y expresa la gran preocupación de los planteamientos políticos de los Reyes Católicos por la reforma (García Oro 1969, 1971; Rubial 2001: 351362) es el que ellos mismos convocaron y que se celebró en Sevilla en el verano de 1478 (del 8 de julio al 1 de agosto), presidido por el cardenal Pedro González de Mendoza en representación de sus dos diócesis de Sevilla y Sigüenza ${ }^{23}$, y con la presencia de fray Hernando de Talavera ${ }^{24}$. Es un concilio donde los reyes buscan el consenso y apoyo de los obispos para hacer una serie de peticiones a la Santa Sede. Pero no por eso dejaron de darse normas concretas al imperioso deseo de reforma que cunde en todos y por todas partes (Fita 1893: 213-257. Con esta afirmación ("en todos y por todas partes") queremos dejar clara la autonomía de la iglesia frente a los reyes y de estos frente a la Iglesia. Esta conserva la iniciativa, aunque el Estado la auxilie y preste su fuerza para llevar a cabo lo que es deseo de todos para el bien del conjunto social ${ }^{25}$. Así se constata el hecho del nombramiento de obispos

20 Debemos subrayar que la elección de Aranda de Duero como lugar de celebración no es neutro, ni tan siquiera que las primeras sesiones fuesen en el gran monasterio de San Pedro de Gumiel de Izán y las siguientes en San Juan Bautista. El contexto político nos da las claves; y es que se percibe cómo el reinado de Enrique IV se desvanecía. Son tiempos de cierta anarquía y pugna entre las clases nobles y la monarquía castellana con las subsiguientes consecuencias de debilitamiento real y de guerra civil con las resultantes consecuencias de la situación sociopolítica a todos los niveles: intrigas en la corte, entre los nobles enfrentados con las derivadas represalias para los pueblos, un descontrol moral dentro de una disensión religiosa fomentada por los conversos falsos tanto judíos como mahometanos en menor número. Como es sabido, Enrique IV muere un año más tarde de la convocatoria de este concilio. En esta situación surgen dos bandos para ocupar el trono: Isabel o Juana la Beltraneja. Es aquí donde el arzobispo Carrillo entra en escena tomando decidido partido por Isabel de Castilla, lo cual, a nuestro entender, es una de las claves de este concilio, pues son dos cuestiones las que se entreveredan: la reforma y la situación política. Ambas habían de ser tenidas en cuenta y no pasó desapercibido para el hábil arzobispo Carrillo, pues el mismo año del concilio Isabel toma posesión de Aranda (6 de octubre de 1473) y los reyes Isabel y Fernando pasan las fiestas de Navidad también allí, según el cronista Zurita. A pesar de todo, Carrillo terminará por oponerse a Isabel dadas sus ambiciones y se pasará al bando de la Beltraneja.

21 La cita pertenece al canon IV. En los demás cánones se pueden ver las propuestas de castigo y exigencia impuestas a los clérigos.

22 Aquí damos el título de cada uno de los cánones del concilio de Aranda que en su enunciado son duros. La razón de tal severidad está en las lacras que se relatan en el desarrollo de los cánones y que son atacadas con toda dureza. Podemos citar en resumen, el amancebamiento o barraganía de los clérigos como vicio frecuente. Así pues, se establece un detallado régimen sancionador que afectará a aquellos clérigos que no cumplan la normativa del celibato sacerdotal. Se prohíbe ordenar sacerdotes a personas que no hablen latín; se dispone que cualquier clérigo que tenga una o varias concubinas de manera pública deberá ser amonestado. También se promulgan normas de conducta para la feligresía censurando las bodas ilícitas y las cuaresmales, además de prohibir las representaciones teatrales en las iglesias y denegar la sepultura eclesiástica a los muertos en duelo y a los ladrones. Se amenaza con excomunión a quienes se apropiaran de los diezmos (materia verdaderamente sagrada; cf. Méndez Pérez 2015: 193-210) y se establece la obligatoriedad del pago de los mismos. Se recupera también la debida atención a la enseñanza de la doctrina cristiana y la revisión de la administración correcta de los sacramentos, entre otras cuestiones menores.

23 Cf. Villalba Ruiz de Toledo 1988: 127, donde puede verse lo referente a ese concilio y la labor de reforma del cardenal Mendoza (ibid. 123-143); igualmente puede consultarse de este mismo autor la Colección Diplomática del cardenal Mendoza (1999) y Vilches Vivancos (1994). Recientemente publicada, puede verse ahora la obra que transcribe el manuscrito de Francisco de Medina y Mendoza, inédito hasta el presente, que lleva por título Suma de la vida del Cardenal Mendoza (ed. García López, 2014). Asisten a este concilio nacional los obispos de Mondoñedo, Ourense, Cádiz, Cordoba, Segovia, Burgos, Cuenca, Palencia, Osma, Astorga, Ciudad Rodrigo, Plasencia, Jaén, Calahorra, Salamanca, así como los procuradores de los obispos de Toledo y de otros varios cabildos.

24 Este hombre, monje jerónimo, asiste por el cargo que ostenta (confesor de la reina), por ser un concilio convocado por los reyes y por el prestigio de ser catedrático de Salamanca; quizás hizo aportaciones al dicho concilio, pues su obra escrita es de tipo moral y muy pastoral. Tal vez esta faceta fue la que le llevó a las manos de la Inquisición por la comprensión mostrada con los judíos y árabes (había llegado a aprender árabe para poder predicarles); cf. Framiñan de Miguel 2005: 27-27, donde encontramos textos de estas dos facetas.

25 Esta visión ha de ser interpretada desde la cosmovisión medieval; cf. Bühler 1977: 39 (aunque la edición alemana es de 1931, consideramos que es un clásico que aporta aspectos muy clarificadores aún hoy). 
con mentalidad y con actuaciones de signo reformador; además, estos tuvieron una repercusión inmediata en la reforma del clero tanto secular como regular, aunque no fuesen las cosas fáciles muchas veces por los enfrentamientos que tuvieron que soportar algunos con los cabildos catedralicios.

A nuestro modo de ver, con esta actuación comienza la reforma del clero castellano y se ponen las bases de lo que va a desarrollarse con la fundación de San Benito el Real de Valladolid, y que llegará convertirse, a pesar de todas las críticas y dificultades, en la reforma de los monasterios españoles. Valladolid no representa sólo un monasterio, sino un "movimiento" que va a cuajar en la Congregación de Valladolid, motor de toda la reforma monástica, pese a que en sus comienzos no se pensase en que fuese Congregación y, por eso, cabeza de la reforma. Pero, sin duda alguna, tuvo, de la mejor y más positiva forma y objetivos, una base política muy fuerte apoyada en ese "movimiento religioso" ${ }^{26}$, tanto en los momentos de su fundación por Juan I, como en el de los posteriores reyes, como los Católicos, cuando escriben a su delegado en Roma (4 de agosto de 1503) para que haga "relación" "a su Santidat y suplicadle, de mi parte, le plega conceder su bulla" para que Valladolid sea cabeza de los monasterios reformados; y añade, en esa misma carta: "y como quiera que sobre todo van allá religiosos d'esta orden, entended vós en la expedición de todo ello con mucho cuidado e diligencia (...) a los quales dichos religiosos avreys por recomendados de manera que bien y brevemente sean despachados"27. Como podemos ver, todas estas actuaciones van poniendo las bases y dando pasos para que Valladolid llegase a ser cabeza de la Congregación ${ }^{28}$.

Otra de las coordenadas con las que hay que contar es el clima creado por el Cisma de Aviñón. Pero si grave era el cisma, el peso de los males que sufría la Iglesia desde la cabeza a sus miembros era general, como venimos apuntando ${ }^{29}$.

Uno de los temas que merece atención es la "Devotio Moderna" ante la sensibilidad religiosa de las masas angustiadas, pues responde a una nueva situación socio-cultural, socio-religiosa, que no puede menos de traducirse y dar respuesta a los deseos de reforma existentes por sus mismas características: una piedad popular "sensiblera" 30 y anti-especulativa, despreciadora de las teorías de las ciencias, morbosa, antisemita, con una fuerte ideología que pesa sobre una orientación exacerbada del desprecio de lo terrenal, la exaltación de la miseria humana; temas, como acabamos de indicar, que nos sitúan en las razones de la reforma. Podemos decir que toda ella se ordena a la práctica de "imitar a Cristo" en su humildad, paciencia, obediencia, de donde el amor a la cruz, sencillez de corazón, etc.; todo ello envuelto en el afecto o "devotio" (sentir aunque no se entienda ${ }^{31}$ ). Así encontraremos a algunos de los grandes abades

26 Cf. Maté Sadornil 2007-08: 85, donde en el prólogo de las Constituciones habla de Juan I como fundador de la "Sancta Observancia" y de "don Fernando Quinto" e "Isabel" como aquellos por cuya "deboçión y favor" la Observancia "ha tanto multiplicado". Desde aquí mi agradecimiento a Lorenzo Maté, actualmente abad de Silos, por el envío de la obra citada, por la amistad y el trabajo compartido en el AHN de Madrid.

27 AHN, Clero, Valladolid, Benedictinos, Legajo 7739, donde está la carta original de la que se han tomado las citas.

28 Cf. Maté Sadornil 2007-08: 73-84, donde ya en la bula de Alejandro VI, del año 1497, al comienzo de las Actas del Capítulo General de 1500 y la del mismo papa del año 1500, se dice expresamente: "conventos dicti monasteri Sancti Benedicto, eisdem Congregationis caput esse deberent" y, por eso, tener "ordinariam iurisdictionem” en todos los demás monasterios (ibid. 80). Para conocer la forma de estructurarse y actuar de la Congregación, véanse estas Constituciones en ibid. 73-131.

29 Así, es necesario subrayar que los papas de esta época (Nicolás V, Sixto IV, Julio II y León X) fueron grandes papas renacentistas, pero, con muy pocas excepciones, el papado no estaba adornado de vida evangélica y, por tanto, con preocupación reformadora. Pensemos en varios papas del s. XV, como Calixto III, Alejandro VI o Inocencio VIII, para darnos cuenta de que lo que les ha preocupado han sido sus negocios nepotistas, sus asuntos políticos y sus mecenazgos (cf. Kasper et al., eds., 2005b: 483-486 y 227-328).

30 No queremos referirnos con esta palabra a algo negativo, sino que, como característica, representa la afectividad, la voluntad, el corazón, la devoción, la entrega generosa frente a las elucubraciones y el desprestigio que venía teniendo la escolástica de los malos seguidores de Tomás de Aquino y de Buenaventura. Cierto que esto lleva en su raíz una falta de fundamentación teológica con una fuerte brecha de separación entre lo que es la teología, la piedad, la mística y el saber científico sobre Dios. Cf. García Villoslada 1956: 315-350. Así dirá Tomás de Kempis que "es preferible sentir la compunción a saber definir" $(1946:$ I, 1, 3).

31 El Cristo de esta postura aparece bastante lejos del Cristo de los evangelios: se moraliza, se astrae y su vida y persona funciona hacia una "ética de virtudes". Por eso se insiste en una práctica métodica de la vida hasta regular el modo de levantarse, comer, rezar, pasear, leer, acostarse, jaculatorias, temas de meditación, etc. (cf. García Villada 1956: 315-350). Dentro de esta corriente de pensamiento cabría citar los Hermanos de la Vida Común, Canónigos Regulares de Windeshein y Tomás de Kempis. Cf. la magnífica síntesis sobre el tema del querido amigo y profesor, al que tanto debemos, Marciano Vidal García (2011: 780-789) y, en especial, Álvarez Gómez (1990: 19-34). 
que tienen relación con la reforma de Valladolid, como es el gran Cisneros que, siendo abad de Monserrat, en 1500, edita Ejercitatorio de la vida espiritual, que llegó a influir en los ejercicios de San Ignacio de Loyola.

Cabe señalar como figuras preocupadas por la reforma en Castilla y León el arzobispo de Toledo, Pedro Tenorio, con sus Constituciones del sínodo de Alcalá ${ }^{32}$; el cardenal legado Pedro de Luna, del que hemos hablado anteriormente, futuro antipapa Benedicto XIII, así como otras figuras como Juan García Manrique (obispo que fue de Compostela), Álvaro de Isorna (Arzobispo de Santiago, servidor y educador de los hijos de Juan I de Castilla), Gutierre de Toledo ${ }^{33}$, Fray Fernando de Illescas, entre otros. Así, autores recientes, con razón, afirman que "la reforma fue en Castilla anterior al centro de Europa" 34 .

Hay un aspecto que no debe pasarse por alto al hablar de las causas de la reforma y es que toda esta situación lleva a un clima de angustia generalizada, como indicamos ya más arriba. Bien pudiera decirse que este es un siglo de interrogantes y contradicción. Por una parte, se hace patente el miedo en la misma liturgia cristiana (las letanías de la época lo deja bien reflejado: "a peste, fame et bello, libéranos, Domine") y en la iconografía (presentando a Dios con tres flechas en la mano: la peste, el hambre y la guerra). Otro de los ingredientes es la muerte como una realidad omnipresente e inseparable del devenir del hombre de esta época (que arranca ya en el siglos anteriores, muy en especial el XIV), con todo el peso de la subsistencia ante las pestes que asolan Europa ${ }^{35}$, como apuntamos más arriba. El memento mori y el tempus fugit como expresión de la muerte, si antes fue vivido como momento duro, ahora se vive como algo patético ${ }^{36}$, tétrico y macabro, con cargas moralizantes muy fuertes hasta considerar la vida como un destierro. Por otra parte, el deseo de disfrutar está presente (recuérdese, por ejemplo, la obra del Arcipreste de $\mathrm{Hita}^{37}$ ), pero sometido a unas pautas morales que, al mismo tiempo no están lejos del sentir bíblico del Quohelet que recorre toda la Edad Media ("Vanidad de vanidades").

Cabe resaltar que esta reforma estuvo muy reforzada por los Manuales de Confesores, como el de Martín de Azpilicueta o el de Jaime de Corella, pues desde ellos hay un control de las conciencias con la imposición de una ideología y costumbres que sería cuidada por la misma inquisición.

\subsection{El contexto social gallego: apuntes ge- nerales}

Una de las claves de las que habría que partir para una adecuada comprensión de todos los hechos de la Galicia medieval es que este

32 Cf. Sánchez Sesa 1995: 289-302, Narbona 1624, Sanchez Herrero 1976: 53-59. El texto del sínodo está en las páginas $243-281$ de la obra citada de Sánchez Herrero y, aunque aparentemente no se tratan cuestiones directamente de reforma, el sínodo se mueve dentro de una corriente general de reforma. Hay cuestiones que sobresalen como en el núm. 7, al hablar de los que se avergonzaban de celebrarla para que lo hiciesen lo más frecuente que puedan (frequencius quam poterit); las leyes de aquel tiempo les obligaban a celebrarla por lo menos cuatro veces al año; de lo contrario se les quitaba lo que recibiesen de su beneficio en ese año. Y el número 8 habla de cómo el pueblo debe venerar las reliquias. Todo el resto de sus 33 números o títulos están dentro de lo que es la reformación de Pedro Tenorio, pues para atajar los excesos y adulterios se hace un desarrollo de los procesos judiciales con un estilo tipo decretal. Tenorio es alumno del famoso decretalista Baldo Degli Ubaldi, doctor en Decretos, y habiendo explicado leyes en Roma no puede hacer otra cosa en el sínodo que aplicar esta formación y forma de expresión, aunque dentro de la más atenta reforma de las costumbres, como deja ver el conjunto del texto del sínodo.

33 Cf. Fernández Conde 1978, donde se puede ver la actuación reformadora de este obispo ovetense y las diversas constituciones para esa reforma.

34 Martínez Millán y Carlos Morales 2011: 116, 110-129; obra recomendable en su conjunto por los aportes contextuales de las distintas épocas.

35 De modo magistral lo expresa la literatura. En el Rimado de Palacio se comenta este aspecto diciendo: "Cierto como flor nace omne, quando reverdece esta carne mesquina; mas aina se podresce, formándose gusanos e peor, quando padesce después en los infiernos, si de aquí lo meresce". Ciertamente no podemos admitir de modo absoluto las afirmaciones del Canciller ya que muchas veces son expresión repetitiva de pensamientos bíblicos, de San Gregorio y de una tradición cristiana donde el peso de lo negativo, desde la ideología que lo alimenta, es el peso de una cierta negatividad que ha de situarse en su contexto para hablar con un mínimo de seriedad. Ahora bien, teniendo en cuenta esto tampoco podemos dejar de afirmar que en las palabras Ayala se revela lo negativo de la sociedad castellana del siglo XIV (cf. Bühler 1977: 260, donde costata la presencia de hombres desengañados y descontentos, en los distintos estamentos de la sociedad, que son el producto de la situación).

36 Este sentido viene alimentado y madura lentamente a través de los sermones, recomendaciones piadosas, meditaciones, moral, etc.; todo ello asentado en una teología de corte negativo y lejana de las fuentes.

37 Igualmente Boccacio, con idéntica maestría, en el prólogo del Decamerón, ante la desolada visión de Florencia devastada por la peste (cf. Fossier 1983: 182, Ariès 1982: 65 y 72). 
territorio, en sus aspectos geográficos, jurídi$\cos \mathrm{y}$, no digamos sociológicos, se configura como "sociedad señorial", con todo lo que esto conlleva de determinantes y mediaciones en todos los sentidos de su desarrollo como tal.

En Galicia podemos decir que los años que median entre 1470-80 a 1520-30 es un periodo clave para su historia. Los conflictos sociales que culminan con la Guerra Irmandiña ${ }^{38}$ que atemoriza a los grandes señores no los lleva a una solución y clarificación de sus tropelías, sino que seguirán con sus complicadas y continuas contiendas creando un clima de inestabilidad y divisiones hasta la implantación de la Santa Hermandad y el envío de Fernando de Acuña como gobernador y justicia mayor del Reino de Galicia (nombrado en 1480) y a García López de Chinchilla. Los monarcas Isabel y Fernando los habían facultado con poderes de excepción permitiéndoles actuar con toda autoridad en cualquier causa civil o criminal $\mathrm{y}$ en cualquier momento del proceso en que se encontrase, levantar en pie de guerra una comarca o zona, así como requerir personas para la guerra. De esta manera, Fernando de Acuña actúa en Galicia con energía y dureza contra la anárquica situación de los poderosos feudales que llevaba la vida de los monasterios, con sus abades y sacerdotes comendatarios ("corozas"), a un gran deterioro moral ${ }^{39}$.

En octubre de 1486 aparecen los monarcas en Galicia dando disposiciones relativas a la reforma del clero regular, pues las distintas comunidades venían atravesando un estado de postración material y moral profunda. Pero mas allá de una reforma religiosa, los monarcas consideran, como medida imprescindible para pacificar el Reino, arrancar de las manos de los nobles legos las rentas que llevaban de los monasterios ${ }^{40}$, como acabamos de indicar. Esta situación se convierte en petición alarmante a los reyes en el Concilio Nacional de Sevilla de 1478 , donde se les pide que pongan mano en este caos que envolvía las iglesias de Galicia (Fita 1893: 228-229). De ahí lo conflictivo y accidentado de la reforma ${ }^{41}$ : enfrentamientos, muertes, etc.

Visto este panorama, podemos afirmar que dentro del clamor general de reforma la española se potencia desde tres frentes: reyes, obispos (con los concilios diocesanos, sínodos, visitas pastorales, etc.; cf. Sánchez Herrero 1976) y clero, entre el que va a tener una gran preponderancia los monjes.

\section{La fundación de San Benito el Real de Valladolid}

Desde el primer momento de su reinado, Juan I siente la necesidad de llevar a cabo una gran reforma eclesiástica, como queda apuntado. La fundación de San Benito no fue un acto aislado, sino una pieza clave de todo el complejo engranaje de la reforma. Piénsese en los dos monasterios fundados con anterioridad: Santa María de Guadalupe (jerónimos) y El Paular (cartujos).

Los antiguos historiadores de San Benito el Real de Valladolid lo hacen surgir de una antigua tradición ${ }^{42}$, pese a no haber ni un solo documento para probarlo, por la que Enrique II, para satisfacción de Dios, debido a la alevosa muerte de su hermano Pedro y por la destrucción de dos monasterios en el reino de Aragón, uno de benedictinos y otro de cartujos, se le impuso como penitencia fundar otros dos monasterios de la misma orden. Pero esto no pudo hacerlo en sus días a causa de las continuas

38 Véase al respecto, entre otros, Barros 1991 y 2006; López Carreira 1991. Una recapitulación crítica en Galbán Malagón 2010.

39 Como ejemplo de esta actuación véase Cebrián Franco 1997: 166-173, donde se narra lo acontecido con el poderoso y belicoso obispo Alonso de Fonseca, que se negaba a entregar la fortaleza de la catedral de Santiago (en 1482 cederá a la fuerza de Fernando de Acuña).

40 De esta situación da buena cuenta la bula de Eugenio IV, de 21 de mayo de 1445, cuando habla de los "clericis corozas", es decir, aquellos clérigos que eran cómplices, por razones de interés, de estas intromisiones de los seglares en los beneficios eclesiásticos (cf. López Ferreiro 1905: 89-90 (Apéndice n ${ }^{\circ}$ XXV; se trata del testamento del arzobispo de Santiago don Álvaro de Isorna, 109-1448). El Padre Yepes, en referencia al monasterio de Irache, hace una tremenda descripción hasta llamar a los que se daba la hacienda "gente vandolera" (cf. Coronica General de San Benito Patriarca de Religiosos, III, fol. 381; puede verse esto mismo en la incompleta o "parcial", como la llama él, edición de Fr. Pérez de Urbel).

41 Puede verse el panorama, no tanto de las dificultades de la reforma, sino de del poder ejercido sobre los monasterios por los hidalgos en García Oro 1977: 50-53 (donde se habla de Chantada) y 1987 (en el tomo I ofrece un amplio y equilibrado panorama de la realidad gallega); vid. también Sá Bravo 1972: 123-149.

42 Cf. Canesi Acevedo 1996: IV, fol. 71rv; Sangrador Vitores 1854: II, 249; Gonzalez García-Valladolid 1901: II, 467; Sangrador Minguela 1904: 111-12; Rodriguez Martínez 1981: 43-44 (quien aclara esta cuestión ateniéndose a la documentación). 
guerras. Será su hijo Juan I el que cumpliría esta exigencia penitencial ${ }^{43}$ por encargo suyo levantando los monasterios del Paular y el de San Benito de Valladolid. Hasta aquí lo que se refiere la tradición; pero no parece que esto pueda sostenerse si miramos al documento fundacional, pues no tiene fundamento serio.

Fuese lo que fuese la tradición, los motivos que llevan a Juan I a fundar el monasterio de San Benito el Real de Valladolid, según el documento fundacional ${ }^{44}$, son los que comentamos a continuación. Por una parte, dar gracias a Dios por los bienes recibidos, pues:

todo aquel que más merçedes e bienes corporales e espirituales resçibe en este mundo de Dios que lo crió, más le es obligado a lo servir e amar e darle gracias e loores por ello, por ende, nos, pensando quantas merçedes e bienes avemos del reçebido e reçebimos de cada día, non por los nuestros merecimientos, mas por la su grande misericordia e piedat que de nos a, queriéndole ser agradeçido e darle gracias por ello de puro coraçón, non tan nobles e dignas gracias como la su real divinal magestad pertenecen, mas segunt la humanal fragilidat puede e requiere.

Amontonar un tesoro de méritos en el cielo: "deseando faser thesoro en los cielos el qual dura por siempre sin peligro alguno a placer e a gloria de aquel que lo fase, el quel tesoro se fase mudando los bienes corrutibles e

43 Mancio de Torres, en el Libro primero de la Historia de San Benito el Real de Valladolid (Ms. 195 de la Biblioteca Universitaria de Santa Cruz de Valladolid, fols. 1-3), se expresa de esta manera: "pero aumentose el daño en todas las órdenes con las guerras entre el rey don Pedro y don Enrique su hermano en el qual tiempo se robaron algunos monasterios y entre estas guerras dicen algunos que el rey don Enrique destruyó dos monasterios en Aragón uno del orden de San Benito y otro de cartujos y que confesándose le mandaron que edificase en sus reynos otros dos y como tomó el reyno y le tubo con tantos trabajos no pudo cumplir la penitencia en esto y encargolo mucho a su hijo el rey don Juan I y, aunque al rey don Juan no le faltaron trabajos y guerras procuró poner en exequción el mandato de su padre y edifico el monastrio del Paular de Sagovia y determinó edificar el de San Benito de Valladolid (...) Yo procuré averiguar esto y hube a las manos un translado autorizado del testamento de rey don enrique II hecho en Burgos a 29 de mayo, de 1374 ante Miguel Ruiz, escribano y un cobdicilo ante el mismo escribano hecho en Sevilla a 7 de mayo de 1376. Y en el testamento manda que cerca de la villa de Montiel, donde fue vencido y muerto don Pedro le haga un monasterio de fraires que sean doze a titulo de Santiago y les den rentas y hagan los oficios divinos por el rey don Pedro al qual entierre delante del altar mayor. Pero en el codicilo que después hizo el dicho rey don Enrique, de allí en dos años en Sevilla, revoca la dicha manda por estas palabras: e otro si por quanto en el dicho nuestro testamento ordenamos e mandamos que por la merced que nos Dios había fecho en que nos dio victoria contra el rey don Pedro nuestro enemigo en que fue vencido e muerto en la batalla de Montiel, que mandábamos que fuese fecho e establecido un monasterio en que hubiese doze freires cerca de la dicha villa de Montiel e que fuese dotado, el dicho monasterio de lugares e de bienes, porque se pudiesen mantener los dichos freires e que fuese enterrado el cuerpo de dicho don Pedro, en el dicho monasterio, Nos agora por quanto después de esto nos fue dado en penitencia que fuésemos y cumpliésemos por su alma otras cosas algunas la[s] quales cosas que nos fueron mandadas por la dicha penitencia por quanto las nos habemos ya cumplido, por esta razón mandamos que el dicho monasterio que habíamos mandado facer que cese e que no se faga. De dicha clausula sacamos que el dicho rey don Enrique II se le impuso penitencia de que hiciese algunas cosas por el alma del rey don Pedro las quales dice que havia ya cumplido, por lo qual manda que no se haga el monastrio en Montiel y las cosas que se le impusieron dice que ya las había cumplido. De manera que de ninguna de estas clusulas consta que le mandasen hacer los monasterios que se refiere el Libro de los Bienhechores, ni en este testamento o cobdicilo hay memoria de que lo encomendase a su hijo don Juan el Primero". Aquí es donde Mancio de Torres, a nuestro parecer, sin tener mucho en cuenta el documento fundacional añade: "Pero podemos decir que fue diferente la penitencia que se le impuso por la muerte de rey don Pedro y la que le dieron por los daños que había hecho y sí dice que lo que tocaba a la muerte del rey don Pedro ya lo había cumplido, y de esto trata en el testamento y codicilo y en lo que toca a los daños parece que lo comunicaría con su hijo y le encomendaría la satisfación y edificio de los monasterios, porque don Enrique II murió dentro de tres años después que hizo el codicilo, que fue año de 1370, y no tubo lugar para cumplir su deseo y así lo encomendó a don Juan el Primero que le heredó de edad de veinte y un años y dos mese y medio y reynó once años y tres meses y veinte díasque intentó enriquecerle e ilustrarle como Yglesia Catedral". Continúa hablando de las gestiones que Juan I hace con el abad de Sahagún y hasta que por la bula de fundación les entregó el "Alcazarejo".

44 Citamos teniendo delante el original (Madrid, AHN, Clero, Benedictinos, Valladolid, carpeta 3445/5). En esta misma carpeta hay varios documentos referentes a la fundación de este monasterio: el $\mathrm{n}^{\mathrm{0}} 7$ tiene la bula de fundación en latín y, en cuatro hojas, con anotaciones a los márgenes, la fundación detallada de San Benito el Real de Valladolid; el nº 6 el "juro" de Juan I de 15.000 maravedíes para San Benito el Real; el n ${ }^{\circ} 11$ una bula para tener campanario; el n ${ }^{\circ} 15$ la confirmación de Enrique III de la donación del Alcázar y la dote para fundar este monasterio; el n ${ }^{\circ} 12$ la bula para tener "cimenterio". Igualmente en los legajos de papeles se puede encontrar numerosa documentación sobre los primeros pasos de la vida de este monasterio. Por lo que se refiere a los motivos de la fundación cabe decir que estos documentos dejan ver que lo que pesa en el fondo es una conciencia escrupulosa de Juan I por las injusticias cometidas, o por lo menos consentidas, por él y reconocidas ante las Cortes de Valladolid en 1385 (cf. Colmeiro 1863: 330-332). El concepto religioso que tiene de su gobierno se percibe bien en sus documentos y en la misma Crónica de Pero López de Ayala. Su confesor, Fernando de Illescas, como reformador va a pesar en esas decisiones. Al respecto de esta problemática cf. Suárez Fernández 1977-82: I, 351-372, donde pueden verse otras causas que le mueven en orden a la fundación y espíritu de reforma que configura su actuación política. Aunque no es el momento de tratar este tema, apuntamos aquí que es necesario un estudio de las formas y palabras usadas en estos documentos fundacionales, pues están expresando una serie de experiencias vitales del rey frente a una concepción peculiar de Dios en referencia a esas experiencias que nos hablan de unas motivaciones que brotan y deben enmarcarse en el turbulento mundo socio-politico religioso que vive Juan I. 
temporales en los bienes perdurables e çelestiales". Que el nombre de Dios y de la Virgen sean servidos por personas santas:

Queriendo (...) e deseando que el su santo nombre, de la Virgen Santa María, su madre e con todos los santos que con él en la su santa gloria viven e regnan sea siempre por personas devotas e religiosas servido e loado, es nuestra voluntad e nuestra entençion, con licencia de nuestro señor el padre santo, la qual liçençia nos es ya por él graciosamente otorgada, de fundar e hedificar en los nuestros regnos en lugar abto e convenible, a servicio de Dios, un monesterio de monjes prietos de La Orden de San Benito.

Que los monjes rueguen por su salud y la de sus descendientes para poder gobernar los reinos encomendados por Dios. Como era habitual desde los tiempos antiguos, a la fundación se le pone la condición de orar por los fundadores y sus familiares, pero aquí se ve en el conjunto que hay un deseo de impetración relacionado con lo político ${ }^{45}$. El documento dice:

porque los dichos monjes que en el dicho monesterio fueren de presente e fueren dende adelante por siempre rueguen a Dios por la nuestra salud e por la nuestra vida e de otros reyes que de nos vinieren, por que gobernemos e rigiamos los regnos que por él nos son acomendados, al su santo servicio e a salvaçion de la nuestra alma.

Así, después de consultar con el abad de Sahagún, Juan de Medina, y con su capellán, Sancho Martínez, abad de Cabañas (y luego arcediano de Campos), el año 1388 decide entregar el Alcázar Real de Valladolid para monasterio. El 21 de septiembre de 1390, en Turégano (Segovia), firma carta disponiendo se arregle el Alcázar para que "bivan e moren en todo tiempo diez e ocho monges profesos de La Regla de San Benito, los quales puedan tener fasta quatro o cinco oficiales servidores que administren las cosas del dicho monesterio"; y se les asigna

por juro de heredat, para mantenimiento de los dichos monges e sus ofiçiales, estas rents que se sigue, conviene a saber: que ayades e ayan, en cada un año, para siempre jamás en lo salvado de las terçias de la dicha villa de Valladolid, seysçientas fanegas de trigo e mil e dosientas cántaras de vino. E si por ventura las dichas seysçientas fanegas de trigo e mil e dossientas cántaras de vino non copieren en las dichas terçias de Valladolid, lo que falleçiere que lo ayades e ayan de las terçias de pan [e] de vino de los lugares más çercanos que andan en la cogecha de la dicha villa. E en el servicio de los judíos de la dicha villa de Valladolid, quince mil maravedises de moneda vieja, los quales quince mil maravedises queremos e mandamos que siempre vos sean tenidos los dichos judíos, para agora e para en todo tiempo, de pagaren moneda vieja o lo que valliere.

Todo esto se condicionaba a la observancia rigurosa de la regla benedictina al estilo de las monjas de Santa Clara, así como la clausura perpetua y que el superior fuse un simple prior. Es más, si esto no se cumpliese,

que por el mismo fecho esta dicha donaçión que nos fasemos del dicho alcaçar e del dicho pan e vino e dineros que vos damos para manteniendo non sean entendidas donados nin sean salvos de nuestro mantenimiento non sean entendidos donados nin sean salvos de nuestro señorio e que nos e los reyes que después de nos regnaren libremente podamos e puedan mandar desenbargar.

El papa Clemente VII, desde Aviñón, reconoció este laudable propósito el 28 de diciembre de $1389^{46}$. Al estar todo preparado, el abad de Sahagún nombró prior de San Benito de Valladolid a Antonio de Ceinos $^{47}$, que era

45 No consideramos desatinado decir, viendo las descripciones que hace Mancio de Torres en el Libro primero de la Historia de San Benito el Real de Valladolid a la que ya aludimos (fols. 72-74) del sello de la elección del segundo prior Juan de Madrigal, que dicho sello tenía a la Virgen María en su asunción y tránsito como tema iconográfico,"y encima un escudo que tiene dos ángele con armas de Castilla, León y Portugal, porque este escudo eran las armas que el rey de Castilla, don Juan I, su fundador traía por haber casado con doña Beatriz, princesa de Portugal, con concierto que el reino que quedase con heredero heredase el otro" (fol. 73v); el tema político está entreverado o en la base de las actuaciones de Juan I y, en concreto, con la cuestión portuguesa de Aljubarrota (cf Colmeiro 1863: 330-332).

46 Cf. Privilegia Praecipua Congregationis Sancti Benedicti Vallesoletani, a Summis Pontificibus concessa et confirmata (Valladolid, 1595, fol. 66). También puede verse en Zaragoza Pascual 1973: 237-238. El original está en el AHN, Clero, Valladolid, carpeta $3445 / 5$.

47 Cf. Zaragoza Pascual 1973: 23-52, donde se nos da detalles de este primer prior perpetuo de Valladolid y paladín de toda la reforma benedictina de los ss. XIV y XV. 
prior del Nogal. Nace así San Benito el Real de Valladolid dando los primeros pasos con catorce monjes de Sahagún y El Nogal. El 27 de septiembre de 1390, reunidos con el prior en la capilla del alcázar donado por Juan I, con el obispo de Oviedo, Guillermo García Manrique, uno de los destinatarios de la bula de Clemente VII (1389), y fray Pedro Belorado, confesor del rey y representante suyo en la ceremonia, se entregó la bula papal al obispo para que la leyese y le diese cumplimiento. Se preguntó a los monjes si aceptaban la bula y, ante la respuesta afirmativa, se leyó la carta regia de fundación. Dado el consentimiento a su contenido quedó, en términos estrictos, fundado San Benito el Real de Valladolid. Todo este ritual se cerró con el rezo de vísperas ${ }^{48}$.

De esta manera se inició la historia del que fue bastión de la observancia, centro y cabeza de la Congregación ${ }^{49}$, de la que dependieron más de cuarenta abadías y otros tantos prioratos. La influencia de la Congregación que nace en torno a San Benito el Real de Valladolid llegó a Portugal, Austria, Inglaterra y América. Pero a los pocos días, el 9 de octubre de 1390, muere Juan I sin sellar la escritura de donación, por lo que los monjes no pueden cobrar rentas. Pese a ello, su vida ganó la simpatía de los vallisoletanos hasta llamarles los "beatos" y los "observantes", e igualmente la de los nobles, pero siendo el sucesor Enrique III, que sube al trono con once años, San Benito se ve sin dotación y en una pobreza y desamparo ${ }^{50}$ por todas las turbulencias habidas por su minoría de edad. Ante tal situación acuden a la infanta de Navarra, hermana del rey, pero no obtuvieron solución al problema de la penuria en que se encontraban. Entusiasmado por la vida de los monjes de San Benito de Valladolid (algunos habían salido de sus prioratos para la fundación), el abad de Sahagún, Juan de Medina, les prometió la ayuda necesaria por cuatro meses e incluso, si no se solucionaba el problema, podría alargarse hasta un año ${ }^{51}$.

Años más tarde, cuando los eclesiásticos que se oponían a la confirmación del privilegio de fundación y dotación dejan de pesar sobre el rey, el 4 de abril de 1391 Salvador Sánchez sella, en nombre de Enrique III, el privilegio que confirmaba la dotación hecha por Juan I, esto es, las tercias reales y varios juros de heredad. El Ayuntamiento y otros pudientes les dieron dinero, heredades, viñas, casas y calles enteras $^{52}$. Incluso el Maestre de Alcántara, don Gonzalo Núñez de Guzmán, parece que llegó a amenazar al poderoso e influyente arzobispo de Toledo, don Pedro Tenorio, cuya influencia durante la minoría de edad del rey Enrique III fue considerable y era uno de los eclesiásticos que más pesaba para que se hiciese la confirmación del privilegio ${ }^{53}$.

A partir de este momento la vida del monasterio de San Benito fue creciendo, como puede verse por la documentación pontificia de esta época, hasta llegar el 21 de agosto de 1395, en que Benedicto XIII le concede una bula para que pueda cobrar las tercias que habían sido dadas a los reyes en varios pueblos de Castilla y que Enrique III cedía al monasterio ${ }^{54}$. Pero, sin duda, la bula que hay que resaltar es la del 2 de mayo de 1398, por la que San Benito el Real de Valladolid queda sujeto inmediatamente al papa; de esta manera, cualquier injerencia, en concreto del arzobispo de Toledo, del obispo de Palencia y del abad de Sahagún, de los que dependían hasta el momento, quedaba anulada ${ }^{55}$.

48 Mancio de Torres, en su Historia de San Benito el Real de Valladolid (fol. 27), cuenta como ha sido la ceremonia y solemnidad con que se ha celebrado. Pero el documento más fidedigno es el acta de fundación (AHN, Clero, Beneditinos Valladolid, carpeta 3445/7), documento transcrito en la obra de Colombás y Gost 1954: 106-110.

49 Debemos dejar claro que la fundación de San Benito no contempla en sus comienzos la idea de fundar una Congregación. Pero las bases de vida reglada harán que a través de los años fermente la idea como necesidad desde la experiencia de reforma y, sin duda alguna, apoyada por la política real de esta comunidad de Alcazarejo de Valladolid.

50 Así lo narra el documento de la fundación de Santa María de Calabazanos: "et del día que fue fundado el dicho monesterio a qatorse días finó el dicho señor rey sin le dexar cosa çierta nin renta segura en que podiesen mantener (...) los monjes que fincaron en este monesterio ençerrados, quedaron en mucha pobresa et grand desanparo" (AHN, Clero, Benedictinos, Valladolid, Capeta $3445 / 18)$.

51 Mancio de Torres, Historia de San Benito el Real de Valladolid, fols. 44-45.

52 Para una visión completa vid. Colombás y Gost 1954: 39-46.

Mancio de Torres, Historia de San Benito el Real de Valladolid, fol. 46

54 AHN, Clero, Benedictinos, Valladolid, carpeta 3446/4. Entre los pueblos que cita están los siguientes: Valladolid, Peñaflor, Villanubla, Puente Duero, Boecillo, Ferrera, Viana, Renedo, Castilnovo, Laguna, Tudela, Santa Cecilia, Cabezón, Santovenia y Olmos.

55 AHN, Clero, Benedictinos, Valladolid, carpeta 3446/15. 


\subsection{La anexión de monasterios a Valladolid}

San Benito el Real de Valladolid, monasterio "prieto" de los "queridos" por Juan I, puesto como ejemplo de la reforma, contó con factores de gran eficacia para llegar a madurar la idea de crear una Observancia Benedictina que agrupase a todos los monasterios de los reinos de Castilla y, más tarde, incorporar a la Congregación todos los benedictinos de España.

Bien es cierto que hasta más de veinticinco años de su fundación, no llegó a ser ni a llevar a término un fuerte liderazgo para ponerse al frente de la reforma desde Valladolid, centro y corazón de Castilla. En 1417, a veintisiete años de su fundación, inicia la aventura reformadora en San Claudio de León. En 1421 en San Bartolomé de Medina del Campo. En 1425, la cabeza cluniacense, San Benito de Sahagún queda bajo la obediencia de Valladolid anexionándose en 1431; y, este mismo año, el 29 de enero se funda Calabazanos (Palencia). San Juan de Burgos quedará sujeto a Valladolid en 1436, gracias al obispo Pablo Santamaría y a la decisión del prior de Valladolid, Fray García de Frías. En 1437 funda el monasterio de Nuestra Señora de la Misericordia de Frómista. En 1449 reforma el monasterio de Sopetrán. En 1450 se reformó Oña. En 1457 Santo Toribio de Liébana. En 1460 fundó el Bueso. En 1458 reformó San Miguel de Zamora. En 1478 San Isidro de Dueñas. Entre los años 1484-92 se reforma en Galicia los monasterios de Santo Estevo de Ribas de $\mathrm{Sil}^{56}$ y se discute el caso de San Andrés de Espinareda.

Se puede decir que todos estos años de luchas y logros fueron entrenamiento para la dura conquista del monacato gallego a la hora de la reforma. Tal reforma suponía, entre otras cosas, que los prelados locales quedaban sometidos al Prior de Valladolid, quien tendría libertad para mover toda clase de personal del monasterio, hacer visitas regularmente y exigir disciplina, e interpretar la Regla en conformidad con las constituciones de Valladolid.

A petición de los reyes Católicos, Alejandro VI, el 26 de marzo de 1494, por un breve e $^{57}$ suyo, encargó al Prior de Valladolid, Fray Juan de San Juan de Luz, que llevase a término la reforma de los monasterios benedictinos de Galicia $^{58}$. Pocos meses pasaron para que Fray Juan recibiese el 4 de julio un seguro mandando a los alcaldes mayores de Galicia que lo apoyaran (a pesar de que ya el 26 de abril de ese año les habían dado órdenes en este sentido). En el mes de octubre ya estaba Fray Juan embarcado en la dura tarea de la reforma de los monasterios gallegos.

Pero a esta dura tarea le acompañaba toda la protección real posible. Por eso los reyes, el 28 de octubre de 1494, volvieron a escribir al gobernador y a los alcaldes mayores de Galicia dándoles normas para que el amparo de fray Juan fuese una realidad, pues se le daban pautas a este reformador para que recuperase los bienes usurpados a los monasterios y esto francamente necesitaba estar bien protegido. El trabajo de Fray Juan fue ímprobo, por lo que nos dejan intuir las fuentes ${ }^{59}$.

\subsection{Las dificultades de la reforma}

No nos resistimos a que sean las situaciones y las cartas de algunos de los grandes reformadores de Valladolid los documentos que subrayen una vez más lo que venimos apuntando como dificultades de la reforma. Por eso nos detendremos a ver los deseos de renuncia de

56 Fray Juan toma posesión y une el monasterio de San Esteban de Ribas de Sil a Valladolid el 18 de octubre de 1494 (AHN, Clero, Benedictinos, Valladolid, legajo 7706).

57 Dicho breve puede verse en Privilegia Praecipua Congregationis Sancti Benedicti Vallesoletani, fols. 133-135 y Zaragoza Pascual 1973: 261-263.

58 Ya antes, a petición de los Reyes Católicos, Alejandro VI expide la bula "Quanta in Dei Ecclesia" (27-7-1493) por la que había encomendado la reforma de los monasterios gallegos al arzobispo de Mesina, Catania y Coria.

59 El documento de posesiones y uniones de los monasterios de Galicia que este reformador llevó a cabo entre los meses de octubre y noviembre de 1594 nos da la idea de un trabajo realizado en un tiempo muy limitado y al que habían precedido largas y duras negociaciones. Dicho documento (AHN, Clero, Benedictinos, Valladolid, legajo 7706) nos da las siguientes fechas de toma de posesión y anexión: San Pedro de Rocas el 18 de octubre de 1494, el mismo día Santo Estevo de Ribas de Sil, Santa Cristina de Ribas de Sil el 19, el 20 San Vicenzo de Pombeiro, el 22 San Vicente do Pino, el 27 Santa María de Ferreira de Pallares, el 29 San Cibrao de Montecubeiro; el 2 de noviembre San Salvador de Lourenzá, el 4 San Martiño de Xuvia, el 5 San Salvador de Bergondo, el 7 Santa María de Cambre, el 8 Santo Tomé de Monteagudo, el 9 San Mamede de Ambía, el 11 Santiago de Mens, el 12 San Xulián de Moraime, el mismo día San Pedro de Vilanova de Dozón, el 15 San Salvador de Lérez, el mismo día San Pedro de (roto) Santiago de Compostela, el 15 San Xoán de Poio; el 3 de diciembre Santa Comba de Naves; y el 26 de marzo de 1495 Sal Salvador de Celanova (aunque el mandato era del 26 de agosto del año anterior). 
Fray Alonso de Toro por las dificultades que encuentra para llevar a cabo la reforma de los monasterios gallegos. Conservamos una carta del general en Roma, fray Andrés Salado, del 20 de julio de 1529, al que Alonso de Toro le había escrito pidiendo la renuncia a su cargo en Valladolid y este le contesta en los siguientes términos:

del propósito que en Galicia tenía de renunciar al cargo en el convento de San Benito, por carecer de pasines y de entender en vydas agenas y por no dar quenta a Dios mas que de sy y que quiere más su anyma que todas las abadías de Castilla, aunque el propósito era muy santo y bueno, como lo es, V.R.P debe mandar mirar con cuanta afección y voluntad aquel santo convento le quiso y quiere por Padre y quanto la Congregación d'ella ha estado y está contenta y de hazer innovación forte subçederían algunos desasosiegos; y pues el premio del buen ministrar es tan grande, no sabría determinar en qual V.R.P. merecería más (...) que soy de parecer se haga sino que se esfuerce y consuele y roguemos al Espíritu Santo ansy lo confirme ${ }^{60}$.

Dado que toca a la provincia de Lugo, en la que se encuentra el monasterio de Chantada, vamos a exponer una serie de problemas que el reformador de la Orden de San Benito de los reinos de Castilla, Galicia "y provincias del Bierzo", fray Rodrigo de Valencia, tuvo con el provisor de Lugo, Min do Con $^{61}$. Conocemos lo sucedido por un aviso que le hace el citado reformador en la "ciudad de Villamayor, de la diócesis de Mondoñedo, a cinco días del mes de julio" del año de $1499^{62}$, para darle a conocer las bulas papales y los documentos reales que tiene para llevar adelante la reforma, puesto que dicho provisor se oponía a ella.

En concreto le da a conocer la bula de Alejandro VI que, refiriéndose a lo que Fernando e Isabel le habían expuesto a su predecesor Inocencio VIII, los monasterios se encontraban "vivendi modi et norma relaxantibus" y disolutamente, por lo que se concedió autoridad a los obispos de Ávila, Córdoba, Segovia y León para reforma, corregir, castigar, disolver o unir monasterios para que se restableciera la observancia según bula del día 11 de diciembre de 1487 .

Igualmente le da a conocer la carta de los Reyes Católicos, firmada en Toledo el 3 de mayo de 1498, enviada al arzobispo de Santiago, Lugo y Ourense, Mondoñedo, Tui, Oviedo y Astorga "e a los deanes e arcedianos e cabildos de las dichas yglesias e a los abades e priores e personas eclesiásticas e religiosas del nuestro Reyno de Galizia con la provincia del Bierzo", así como al gobernador, "lugar teneniente", capitán y alcaldes mayores. El breve papal mandaba al prior de San Benito, Rodrigo de Valencia, o a quien él concediese delegación "para que atendiese en la entera reformación que antes sydo començada" por el obispo de Catania "de nuestro consejo" y ahora había delegado en dicho prior. Así pues, los reyes mandan que el dicho prior sea recibido como reformador para que se cumplan las bulas y breves del papa y todo lo que mandasen y dispusiesen acerca de la reforma de los monasterios; y también que "deades e fasades dar todo el favor e ayuda que pidiese e menester oviese e obedezcais sus cartas e mandamientos (...) e vos junteys e confirmeis todos con él para ello e que en ello ni en parte d'ello le non pongays ni consintais poner enbargo ni contrario alguno", pues también es voluntad real que "los dichos monasterios enteramente sean reformados e reducidos a la observancia e verdadera comunidad". Ante todo lo dicho se reafirma la carta real con imposición de diez mil maravedíes a quien se oponga a ella.

Pero el empeño de los reyes es tan fuerte en la reforma que la reina Isabel, el 7 de marzo de 1497, en Burgos, escribe una carta contra todos cuantos "con syniestras rellaciones procuran algunas bulas e breves (...) contra la dicha reformación ynpetrando las abadías e ganando otras facultades con que se ynpida e desaga la dicha reformación", pues si el papa fuese debidamente informado no concedería lo que "nos tiene a nosotros otorgado e conçedido". Por esta razón manda sean presentadas para que "sy tales fueren que devan ser ejecutadas nos las mandaremos luego ejecutar o lo notyficaremos al nuestro muy santo Padre

60 AHN, Clero, Valladolid, Benedictinos, legajo 7704.

61 En el documento citado aparece con dos grafías: "al dicho min do con" y "Min do Ocon". Conservamos la grafia que aparece claramente en el documento, aunque pudiera ser escrito junto.

62 AHN, Clero, Valladolid, Benedictinos, legajo 7706. Todas las citas literales que aparecen a continuación son de este documento. 
para que informado de la verdad su Santidad lo mande remediar a lo que su Santidad mandase se cumpla en otra manera no deys lugar a cosa alguna que se faga de lo suso dicho syn que primeramente nos aviseys de todo ello e mandemos lo que sobre ello se deva faser".

Notificados estos documentos en 18 de diciembre de 1498, se le "insta", al provisor de Lugo, bajo la pena de cincuenta mil maravedíes para el fisco real además de perder su cargo y bienes a que desista de toda oposición a la reforma. Además,

[se le] dio e denunció cierta querella y acusación contra vos diziendo que porque nos ovimos mandado prender a Juan de la Portela, racionero de la dicha iglesia [de Lugo], porque fue contra la dicha reformaçión e contra lo por sus altesas mandado diz que aveys proçedido contra Juan Barrientos, aguaczil e contra los que con él yvan a prender al dicho clérigo por censuras eclesiásticas e aveys fecho vuestro proceso contra ellos, Y que, asy mismo prendistes a fray Juan de Gontyn, monje del monasterio de Santa María de Ferreira de Pallares, que es de la dicha orden de San Benito, no teniendo poder ni jurisdicción paraello. Y que asy mismo vos entremeteys y entremetystes a dar carta de excomunión a Ruy Fernández, arçipreste de Mave e a Constanza V[asque]s, abadesa que fue del monesterio de Sant Julián de Alovios, nuestra monja e religiosa para que se ponga, como se pone de fecho contra la dicha reformaçión. Y que, otrosy, demandays al monesterio de Santa Maria de Pesqueiras, que es de la dicha Orden de San Benito dos moyos de pan e vino no se los deviendo ni siendo obligodo el dicho monesterio a dar cosa alguna. Y que vos aveys entrometido y entremeteys en otras cosas e viniendo contra la dicha reformaçión e traspasandolos dichos mandamientos apostólicos e reales por lo que diz que aveys caydo e yncurrido en grandes e graves penas a vos pido que aviendo la dicha su relación por verdadera pro é diesemos contra vos por cada censura eclisiástica y vos condepnasemos en las dichas penas en que asy aveis oydo e incurrido según que esto y otras cosas más largamente en la dicha su denunçaaçión y querella se contiene.
Así pues, incurriendo en grandes y graves penas pide al notario lleve a cabo un "munitorio" contra él y proceda por cada censura eclesiástica y "vos condepnasemos en las dichas penas en que asy aveys caido e yncurrido". Por eso,

en virtud de santa obediencia e so pena descomunión mayor autoritate apostólica, de que en esta parte usamos, vos mandamos primo, segundo del día que esta carta os fuese noyficada en vuestra persona o a las puertas de vuestra morada, donde más continuamente soleys habitar y morar dizindolo e haziendolo saber a vuestro criados, sy los avedes, o de la forma que más pronto llegue a vuestra noticia, dándoos tres días de plazo (...) revoquéis e deys por ninguno todo lo contra el dicho aguazil e sus consortes fezistes e teneys fecho y todo cuanto hicisteis y mandasteis contra la reforma y los dichos monasterios y os inhibáis de todo.

Vistos estos detalles del proceso de fray Rodrigo de Valencia contra el provisor de Lugo, podemos concluir que la reforma en general, y en Galicia en particular, no fue fácil. Podemos presentar numerosos procesos como este contra otras personas en los que se muestra la oposición y dureza con la que se actuó para que la reforma propuesta desde Valladolid con el apoyo papal y real no se llevase a cabo.

\subsection{La anexión de Chantada}

Por lo que se refiere a la anexión de Chantada desconocemos el momento en que comenzaron las entrevistas y negociaciones de anexión y toda la problemática que pudo haber. Pero, posiblemente entre 1492 y 1494, se vivió un momento de negociaciones intenso, puesto que ya en 1494 encontramos a Chantada como priorato de San Benito de Valladolid. Esta anexión quedó confirmada por bula de Alejandro VI el 18 de mayo de $1496^{63}$. En ella se indica que Valladolid tome la posesión al morir el abad que tenía el monasterio a no ser que este dejase la abadía en vida. San Benito el Real de Valladolid, fuimos acotando el tiempo y clarificando el lugar donde podría encontrarse la citada bula. Finalmente, en marzo de 1992, vimos por primera vez el documento auténtico citado por los autores, pero no consultado. La fecha quinto decimo, kalendas Junii Pontificatus nostri anno quarto" (el documento completo se transcribe en Méndez Pérez, Otero Piñeyro Maseda y Romaní Martínez 2016: 629-632, doc. 279). 
No sabemos con certeza los conflictos que tuvo el monasterio con Esteban Fernández de Camporramiro, arcediano de "Castella" en Ourense y canónigo de la iglesia de Santiago ${ }^{64}$, pues todas las noticias que hablan de que "impetró" la abadía a la muerte del último abad son fragmentarias y algunas posiblemente tendenciosas. Así, en una relación que hace este tal Esteban de Camporramiro, llega a decir que cuando los monjes

anexaron el dicho monasterio de Chantada al dicho Sant Benito hizieron relación falsa diziendo que la abbadía y monasterio de Chantada era poca cosa y que no se podían sustentar en el dicho monasterio de Chantada frayres ni convento, porque no tenían de que vevir, porque estaba en tierra áspera pa poder vivir por lo qual suplicaban a su santidad o a quien para ello les parecía tener poder lo diese por bien de anexarlo al dicho monasterio de Sant Benito de Valladolid para una chathedra donde leyesen a los frayles la cual nunca han tenido (...) probaré cuando la dicha abbadía de Chantada la poseía el dicho Álvaro da Pena, abbad mi antecesor, por cuya muerte yo la impetré, que siempre en ella ovo siete o ocho frayres profesos e abad, prior e convento para lo qual era dada la renta de la dicha abbadía en la mesa abbatial e mesa conventual e provenda para prior e más había el dicho monasterio dos o tres clérigos seculares que administraban los oficios divinos en los anexos del dicho monasterio y ansi mismo en dicho monasterio de Chantada cáliz de plata e cruz e ornamentos rycos e todas otras cosas que eran necesarias al dicho monasterio para administración de los oficios divinos ${ }^{64}$.

Como hemos indicado, él trataba de conseguir la abadía, pues era hombre que buscaba toda clase de prebendas. Así vemos, en este mismo documento, como había impetrado también la abadía de Celanova, por eso trata, quizás con cierta exageración, de desacreditar todo lo que Valladolid estaba haciendo con la reforma, llegando a decir que se administraba "mucha justicia a sus vasallos fasta que vino la observancia que no más en aquellos monasterio ovo frayles ni clérigos ni missa ni menos justicia a el dicho monasterio de Chantada palaçio y casas e a todo por tierra como otros muchos que en aquel reyno perdidos e de casas de oración que solían ser son (...) ladrones e corrales de boys e bacas e de otros animales más brutos"; $y$, de los siete u ocho frailes que antes había en Chantada, después de la reforma dice que sólo queda uno. Por eso, ataca a la reforma diciendo: "buena reforma que la observancia ha hecho por todo el Reyno de Galiçia". Así pues, llega a manifestar que la relación que han hecho los monjes de Chantada para la anexión a Valladolid es falsa, puesto que dijeron que las rentas no valían más que setenta ducados, pero él sabe que valen unos setecientos o más, de donde que el abad tuviese miedo y se ausentase de la abadía para que no le llevasen preso a Valladolid como habían hecho con otros. Ciertamente, este hombre debió de ser una pesadilla para los monjes de Valladolid, puesto que en Roma traía muchos pleitos contra ellos por este monasterio de Chantada, por el Arcedianazgo de Celanova y su monasterio, como deja ver la documentación conservada ${ }^{66}$.

Concluyendo hemos de decir que no tenemos noticias de ninguna de las negociaciones o problemas, si los hubo, de lo fue la anexión a Valladolid. Pero, sí encontramos dos personas que, según la documentación de Chantada, debieron estar apoderadas del monasterio aún después de la anexión. Una de ellas es Álvaro López do Bañal, que aparce en 1497 aforando bienes de Chantada; pero al año siguiente aparece como "mordomo del mosteiro"67. Esto nos hace pensar que en Chantada, en los inicios de la anexión, hubo una dualidad de poder y quizás no carente de tensiones. Otro de los personajes es Lopo Rodríguez de Riocabo, que bien podemos considerarlo el hombre fuerte de Fray Pedro de Zamora, pues aparece en la documentación con el título de "escudero" y "merino" del monasterio, por virtud de un poder

64 Lamentamos no poder dar la cita de esta documentación, dado que nos ha sido enviada, hace años, a Madrid sin signatura, y cuando intentamos localizarla la búsqueda fue infructuosa; en cualquier caso, la documentación se encuentra en El Archivo de la Catedral de Ourense. Por las fotocopias de la documentación que conservamos, comprobamos que era un hombre rico por lo que entrega a la catedral: "una arca de marfil, labrada y entallada de istorias toda alrededor e forrada de dentro de damasco", "un mosendero blanco de plumas de pavo", "una caxa de cuero labrada de oro por cima para poner los corporales", "dos almozadas de carmesí y pelo colorado", "otras de pano amarillo con las armas de dicho Camporramiro".

65 AHN, Clero, Benedictinos, Valladolid, legajo 7722.

66 Cf. AHN, Códices, 881B, fol. 154 y 898B, en donde aparecen datos de gastos por los negocios y pleitos en Roma que traen en San Benito el Real de Valladolid contra Esteban de Camporramiro.

67 Cf. Méndez Perez et al. 2016: docs. 281, 283, 286, 289 y 315. 
que "yo tengo del reverendo padre fray Pedro de Çamora, subdelegado de la Orden de san Venito deste reino de Galizia"68, y aforando desde enero de 1513 a noviembre de 1524.

Toda esta situación de ambigüedad y tensión de poderes queda zanjada con un buleto del papa León $\mathrm{X}^{69}$ en el que se ordena que los monasterios de San Xulián de Moraime y de San Salvador de Chantada, anexados anteriormente a Valladolid, transfieran todo el derecho que tenían sobre sus bienes al monasterio de San Benito. De esta manera, San Salvador de Chantada queda efectivamente anexado y dependiente totalmente del Real de Valladolid.

Retomando lo dicho al comienzo de este trabajo, es en esta situación desde donde cabe entender y ver las expresiones de presión, dependencia y dominio que encontramos en estas últimas visitas de la vida del monasterio de San Salvador de Chantada antes de la mal llamada desamortización de Mendizábal.

\section{Texto de las visitas conservadas y cono- cidas de Chantada}

Son pocas las visitas que hasta el momento conservamos $-\mathrm{o}$ que conocemos- de este monasterio. En total cuatro de los años 1819 (3 de septiembre), 1825 ("veinte y [...] de agosto" ${ }^{\circ 0}$ ), 1829 (20 de agosto) y 1833 (10 de septiembre). Como podremos ver en los textos conservados, la visita fue uno de los principales instrumentos de control de los prioratos por parte de San Benito el Real de Valladolid. Las cuestiones tratadas en las visitas son múltiples, centrándose principalmente en dos aspectos: el temporal (administración, deudas, estado del monasterio, etc.) y el aspecto de regla y costumbres o espiritual.

Hechas estas breves anotaciones, dejamos que sea el texto conservado en Madrid ${ }^{71}$ (AHN, Clero, Valladolid, Benedictinos, Libro 16778) el que nos introduzca en los aspectos citados anteriomente. Desde ellos podremos ver el sometimiento que impone Valladolid y, de ahí, las exigencias impuestas reiteradamente en las distintas visitas de estos años.

\subsection{Visita en 1819}

Nos el P[adre] M[aestro] fr[ay] Andrés de Castro, M[aes]tro Gen[era]l de la Relig[ió]n de $\mathrm{S}[\mathrm{a}] \mathrm{n}$ Benito y abad del R[ea]l Monast[eri]o de Valladolid, sus filiacion[e]s, anejos y prijoratos ( $\mathrm{sic}$ ) etc. Habiendo visitado esta casa de $\mathrm{S}[\mathrm{a}] \mathrm{n}$ Salvador de Asma y su iglesia, y vista la decencia con $\mathrm{q}[\mathrm{u}] \mathrm{e}$ el S[antísi]mo Sacramento, sagrados oleos y pila baptismal, lo que nos pareció mandar p[ar]a maior servicio de Nuestro Señor y aumento de este pryorato, habiéndolo consultado antes con el p[adre] pryor es lo siguiente:

$1^{\circ}$.- Primeram[en]te encargamos la conciencia al $\mathrm{p}$ [adre] pryor que guarde y mande guardar los mandam[ien]tos de la ley de Dios y de la S[an]ta M[adr]e Yglesia, Regla de N[uestro] P[adre] San Benito, Constitucio[ne]s y ceremonias, loables costumbres de esta casa, juntam[en]te con esta $s[a n]$ ta visita.

$2^{\circ}$.- Otrosí, mandamos q[u]e antes de cenar o de hacer colación en los días de ayuno, así regulares como de la Yglesia, se continue la santa costumbre de cantar todos los días la salve y un responso desp[ué]s de ella $\mathrm{p}[\mathrm{o}] \mathrm{r}$ los bienhechores de esta casa, haciendo lucir dos velas de cera mientras dure uno y otro y, en los días clásicos y fiestas principales del año, se cante igualmente la misa maior y se rece en el coro el oficio divino quando buenam[en]te se pudiese.

$3^{\circ}$.- Otrosí, encargamos al $\mathrm{p}[$ adre] prior y $\mathrm{p}[$ adres] curas, a saber de estas n[uest]ras parroquias de s[a]n Salvador de Asma, de s[an]ta $\mathrm{M}[$ arí $] \mathrm{a}$ de Camporramiro y Santiago de

Ibid. docs. 320, 321, 324, 327, 328, 329, 332, 334, 336, 337, 340, 341 у 342.

Ibid. doc. 338 .

70 Desconocemos el día, puesto que muchas veces, en estos y otros documentos, la fecha se escribía en el momento de ser otorgado o leído públicamente a la comunidad, junto con otros detalles, por lo que se dejaba el espacio para completar el documento que estaba escrito de antemano. Posiblemente fuese así el caso de esta visita: se escribió para ser leída "en presencia del prior y demás monjes, en este priorato de San Salvador", pero quizás se olvidaron de completar el detalle de la fecha, que llegó hasta nosotros incompleta.

71 La transcripción que ofrecemos es conservadora, para dar a conocer el texto tal como aparece en el manuscrito. Como todos los textos de esta época es bastante irregular en su ortografía. Utilizamos las siguientes convenciones editoriales: los corchetes [ ] señalan la reconstrucción de las letras que faltan en las distintas palabras, [...] cuando se trata de secuencias ilegibles por deterioro o mutilación; las barras inclinadas $\backslash$ / indican que el texto aparece entre renglones o escrito sobre las palabras de un renglón, los paréntesis ( ) delimitan los lugares de las firmas, aclarando con letra cursiva que está rubricado. 
$\mathrm{Arriba}^{72}$ la maior decencia en sus yglesias, haciendo arder continuam[en]te en ellas una lámpara delante de S[antísi]mo Sacramento. Y $\mathrm{p}$ [ar]a que esta $\mathrm{n}$ [uest]ra dispos[ici]ón tenga el debido cumplim[ien]to, mandamos a d[ic]hos $\mathrm{p}$ [adre] pryor y curas $\mathrm{q}[\mathrm{u}] \mathrm{e}$ a los $\mathrm{q}[\mathrm{u}] \mathrm{e}$ pidieren sepulturas en las capillas mayores se las concedan pagando tres ducados por cada una de ellas, cuio caudal, juntam[en]te con el de otras limosnas o fundaciones, si la hubiere, se aplicará, desp[ué]s de otros cargos precisos de $d[i c]$ has yglesias, p[ar]a mantenim[ien]to de $\mathrm{d}[\mathrm{ic}]$ has lámp[ara]s, quedando a su cargo y oblig[aci]ón, con la que estrecham[en]te les reconvenimos, suplir cada uno por su parte lo $\mathrm{q}[\mathrm{u}] \mathrm{e}$ falte y sea necesario para una luz continua en todo el año delante de S[antísi]mo Sacramento.

4.- Otrosí, encargamos a los s[eñores] $\mathrm{p}$ [adres] curas cumplan con las obligacion[e]s de tales celando con toda atención y cuidado $\mathrm{q}[\mathrm{u}] \mathrm{e}$ sus feligreses vivan en el $\mathrm{s}[\mathrm{an}]$ to temor de $\mathrm{D}[\mathrm{io}] \mathrm{s}$ predicándoles el evangelio los días festivos, enseñandoles y explicándoles la doctrina cristiana, especialm[en]te por Adviento y Quaresma, y exortando constantem[en]te a la práctica de las virtudes y detestación de los vicios y malas costumbres y ad[e]más les prevenimos anoten con toda puntualid[a]d y en la mejor forma en los respectivos libros las partidas de los baptizados, casados y difuntos con la razón o minuta de los confirmados, remitiéndonos, sin disculpa alg[u]na, cada año, certificación jurada de haberlo ejecutado así y de no haber omitido partida alguna y procuren así mismo el más exacto cumplim[ien]to de los testam[en]tos y fundacion[e]s piadosas y de satisfacer juntos con el padre prior en los términos $\mathrm{q}[\mathrm{u}] \mathrm{e} \mathrm{h}[\mathrm{as}]$ ta aquí las mis[ma]s que tiene de oblig[ació]n o contra si este pryorato.

5.- Otrosí, mandamos a los p[adre]s curas de Camporramiro y Santiago de Arriba que se hallan residiendo, de alg[uno]s años a esta $\mathrm{p}[\mathrm{ar}] \mathrm{te}$, en sus respectivas parroquias asistan actualm[en]te en ellas sin $\mathrm{q}[\mathrm{u}] \mathrm{e}$ puedan pernoctar fuera sin liz[enci]a del $\mathrm{p}$ [dre] pryor de este pryorato (como individuos y conventuales $\mathrm{q}[\mathrm{u}] \mathrm{e}$ son d él) y el p[adre] pryor, a q[uie]n facultamos $\mathrm{p}$ [ar]a darla de tres o quatro días, se arreglará a lo que disponen $n$ [uest]ras leyes en el particular. Y en atención a $\mathrm{q}[\mathrm{u}] \mathrm{e}$ por las circunst[ancia]s pasadas y causas bien notorias desde el año de mil ochocientos once han percivido $\mathrm{d}[\mathrm{ic}]$ hos $\mathrm{p}$ [adres] curas en lug[a]r de la congrua que se les tenía señalada de doce fanegas de centeno, doce canados de vino, doscientos ducados en dinero y dos arrobas de az[ei]te p[ar]a la lámpara, todos los diezmos y emolumentos de sus respectivos curatos, permitimos los sigan perciviendo h[as]ta que por nos o n[uest]ros sucesores, en visita o fuera de ellas, se determine otra cosa quedando a su cargo y oblig[aci]ón de satisfacer tod[a]s las cargas y pension[e]s anejas a $\mathrm{d}[\mathrm{ic}]$ hos curados o yglesias de la limosna a los pobres de sus parroquias y, al mismo tiempo, de contribuir a esta casa o pryorato el $\mathrm{p}$ [adre] cura de Santiago de Arriba con quince canados de vino y el $\mathrm{p}$ [adre]cura de Camporramiro con cinco canados de vino, dos costales afanegados de castañas verdes y toda la paja triga y de cebada, los quales canados llevará el $\mathrm{p}$ [adre] pryor al libro de bodega y se hará cargo de ellos.

6.- Otrosí, $\mathrm{p}[\mathrm{o}] \mathrm{r}$ ser esenciales de nuestro ynstituto los votos de clausura y pobreza $\mathrm{p}$ [ar]a su más puntual observancia mandamos a los monjes conventuales de este priorato $\mathrm{q}[\mathrm{u}] \mathrm{e}$, en cumplimiento de las Constituciones $\mathrm{q}[\mathrm{u}] \mathrm{e}$ de esto tratan y siguiendo con todo su tenor, no salgan, sin licencia expresa del $\mathrm{p}$ [adre] prior o presidente, de la clausura determinada señaladam[en]te en la visita de mil setecientos och[en]ta y seis, para salir de dicha clausura no salga un monje solo no siendo el $\mathrm{p}$ [adre] cura $\mathrm{p}$ [ar]a precisa administ[ració]n del curato o $\mathrm{p}$ [ar]a particular negocio de este priorato $\mathrm{y}$, vajo el mismo precepto, mandamos haga un depósito común donde se pongan los peculios particulares y no se pueda sacar de él cantidad alguna, ni recivirse, ni gastarse sin licencia expresa del $\mathrm{p}$ [adre] prior o presidente en su ausencia y se prebiene al $\mathrm{p}$ [adre] prior por lo perteneciente a su persona, como a las licencias $\mathrm{q}[\mathrm{u}] \mathrm{e}$ a nombre $\mathrm{n}$ [uest]ro diera a los tres

72 Aunque el Nomenclátor de Galicia. Lugo (2000: 47) aparece también "Arriba", consideramos más acorde con la toponimia, contando con la documentación medieval que se refiere a este lugar, que debería escribirse "Santiago de Riba" (cf. Ares Vázquez 2013: 810). Desde aquí mi agradecimiento al amigo y profesor Nicandro que tanto me animó y ayudó en aquilatar varias palabras de la transcripción de algunos documentos del Monasterio de San Salvador de Chantada, por su descorcertado y desconcertante latín, como los dos primeros textos de 1073 y la bula de anexión, entre otros. 
padres curas conventuales de este n[uest]ro priorato, $\mathrm{q}[\mathrm{u}] \mathrm{e}$ no se crean, por manera alguna, con facultades para gastos extraordinarios, así en el modo como en la substancia comprando o haciéndose con alajas notablemente costosas como tampoco $\mathrm{p}$ [ar]a regalar y hazer expresiones, aunq[u]e sea a los monjes de la Congregación $\mathrm{q}[\mathrm{u}]$ e no sean muy moderadas.

7.- Otrosí, para precaver los graves perjuicios $\mathrm{q}[\mathrm{u}]$ e de los emprestitos $\mathrm{q}[\mathrm{u}]$ e hasta aquí se hicieron se han experimentado, mandamos a $\mathrm{d}[\mathrm{ic}]$ ho $\mathrm{p}$ [adre] prior y monjes conventuales no presten cantidad alguna $\mathrm{q}[\mathrm{u}] \mathrm{e}$ pase de sesenta $\mathrm{r}$ [eale]s sin recibir prenda $\mathrm{q}[\mathrm{u}] \mathrm{e}$ por lo menos exceda su valor a una tercera parte del total del empréstito. Y así bien les prohibimos reciban y retengan en su poder $\mathrm{p}[\mathrm{o}] \mathrm{r}$ vía de depósito cantidad alguna ni otros bienes pertenecientes a personas seculares, aunq[u]e sean criados de la Religión o actuales sirvientes del priorato respectos de los qua les encargamos muy estrechamente al $\mathrm{p}[$ adre] prior, sobre $\mathrm{q}[\mathrm{u}] \mathrm{e}$ le grabamos su conciencia y respectibam[en]te a los pad[re]s curas de afuera por lo perteneciente a los suyos, en cuidado de apuntar con toda claridad y precisión en su libro de caja la soldada en $\mathrm{q}[\mathrm{u}] \mathrm{e}$ los tienen ajustados y de habérselas satisfecho, como lo deben hazer siempre al fin de cada año, exponiéndolo así en los memoriales $\mathrm{q}[\mathrm{u}] \mathrm{e}$ en las visitas deben entregarnos.

8.- Otrosí, mandamos al $\mathrm{p}[$ adre $]$ prior, $\mathrm{q}[\mathrm{u}] \mathrm{e}$ es o fuere, $\mathrm{q}[\mathrm{u}] \mathrm{e}$ todos los años $\mathrm{p}[\mathrm{o}] \mathrm{r} \mathrm{S}[\mathrm{a}] \mathrm{n}$ Juan de junio forme y estienda las quentas en los respectivos libros con especificación de lo $\mathrm{q}[\mathrm{u}] \mathrm{e}$ tienen en ser y de lo $\mathrm{q}[\mathrm{u}] \mathrm{e}$ resulta en liquidación o partidas abiertas, remitiendo sin escusa alguna copia de dichas quentas a $\mathrm{n}$ [uest]ro monast[eri]o de Valladolid para trasladarlas al libro de prioratos y el año de capítulo practiq[u]e la misma diligencia antes de Pascuas de Resurección expresando el estado en que quede el priorato. Y quando en él haya de entrar nuevo prior, entre éste y él q[u]e concluia, se formen quentas finales y haga formal entrega de todos los ajuares y alajas propias de esta casa cuias quentas e inventario de alajas firmen uno y otro. Y habiendo observado $\mathrm{q}[\mathrm{u}] \mathrm{e}$ de algunos años a esta parte ha abido un escandaloso descuido en cubrir las partidas de los encavezados en sus respectivos libros, $\mathrm{q}[\mathrm{u}] \mathrm{e}$ son los únicos feacientes para la realidad de nuestras cuentas, mandamos al p[adre] prior, sobre $\mathrm{q}[\mathrm{u}] \mathrm{e}$ le grabamos la conciencia, escriva en $\mathrm{d}[\mathrm{ic}]$ hos encabezados las partidas $\mathrm{q}[\mathrm{u}] \mathrm{e}$ se hayan cobrado y en adelante cobraren y de los nuevos encabezados de rentas $\mathrm{q}[\mathrm{u}] \mathrm{e}$ formare $(\mathrm{q}[\mathrm{u}] \mathrm{e}$ deberá ser $\mathrm{p}[\mathrm{o}] \mathrm{r}$ lo menos una vez en el quatrienio) remitirá copia literal a $\mathrm{d}[\mathrm{ic}] \mathrm{ho}$ $\mathrm{n}$ [uest]ro monasterio de Vallad[oli]d.

9.- Otrosí, por quanto a más del veneficio $\mathrm{q}[\mathrm{u}] \mathrm{e}$ resulta de la cobranza de laudemios es muy conducente a la mayor seguridad de las haciendas y más fácil cobranza de las rentas, mandamos al $\mathrm{p}$ [adre] prior averigüe con toda solicitud las ventas $\mathrm{q}[\mathrm{u}] \mathrm{e}$ se hicieren de los bienes aforados $\mathrm{p}[\mathrm{o}] \mathrm{r}$ este priorato y procurando $\mathrm{q}[\mathrm{u}] \mathrm{e}$ los nuebos posedores reconozcan el directo dominio de esta casa, paguen efectivam[en]te los laudemios.

10.- Otrosí, reconoziendo $\mathrm{q}[\mathrm{u}] \mathrm{e}$ de la incuria, condescendencia o compasión mal entendida con $\mathrm{q}[\mathrm{u}] \mathrm{e}$ hasta aquí se ha procedido en las cobranzas de este priorato, no sólo ha resultado contra él considerables perjuicios, sino también contra los mismo colonos dejándoles cargar un año sobre otro imposibilitándose de esta manera más y más a la paga, mandamos al $\mathrm{p}$ [adre] prior, $\mathrm{q}[\mathrm{u}] \mathrm{e}$ es o fuere, no deje pasar año alguno sin cobrar de cada colono las rentas correspondientes al tiempo de su administración sin dejar partida alguna abierta $\sin \mathrm{q}[\mathrm{u}] \mathrm{e}$ presente y haga constar las diligencias judiciales y extrajudiciales que para el efecto y en cumplimiento de este mandato haya practicado y por lo respectivo a las quantiosas rentas $\mathrm{q}[\mathrm{u}] \mathrm{e}$ resultan por cobrar, le mandamos practique las más enérgicas y eficaces diligencias para su aborto dirijiéndolas, siempre que haya lugar, contra los principales foreros se le permite no obstante hacer algunas prudentes condonaciones a los colonos indigentes $\mathrm{q}[\mathrm{u}] \mathrm{e}$ por pura necesidad hayan diferido las pagas y las cantidades causadas de dichas cobranzas se lleben al Libro de Depósito con expresión de los valores corrientes en los años $\mathrm{q}[\mathrm{u}] \mathrm{e}$ se contrajeron las deudas.

11.- Otrosí, mandamos al p[adre] prior averigüe con toda diligencia las porciones de terreno $\mathrm{q}[\mathrm{u}] \mathrm{e}$ se roturan y cultivan en el monte de San Sebastián y más terrenos propios de este priorato y cobre de todos sus frutos $\mathrm{q}[\mathrm{u}] \mathrm{e}$ en ellos se causaren, además del diezmo, un quinto íntegro por razón del directo dominio y estas partidas las anote y tome en cargo en los libros a que correspondan y así mismo le prebenimos $\mathrm{q}[\mathrm{u}] \mathrm{e}$ de aquí en adelante no sólo pasaremos en descargo alguno de las partidas de leña $\mathrm{q}[\mathrm{u}] \mathrm{e}$ comprare para el uso de esta casa 
atendiendo $\mathrm{q}[\mathrm{u}] \mathrm{e}$ de los diestros y dehesas $\mathrm{q}[\mathrm{u}] \mathrm{e}$ que beneficia puede cortarse la suficiente para el consumo. Y atendiendo igualm[en]te a que n[uest]ro monast[eri]o de Vall[adoli]d se halla en el mayor apuro y urgencia para mantenerse, prohibimos a d[ic]ho $\mathrm{p}$ [adre] prior compre alaja alguna para el servicio de la casa o haga otra en ella $\mathrm{q}[\mathrm{u}] \mathrm{e}$ exceda de doscientos r[eale]s sin darnos parte de ello y obtener así n[uest]ro consentim[ien]to.

12.- Otrosí reconvenimos al $\mathrm{p}$ [adre] prior $\mathrm{y}$ respectibam[en]te a los pad[re]s curas con lo $\mathrm{q}[\mathrm{u}] \mathrm{e}$ ordenan y disponen $\mathrm{n}[\mathrm{uest}$ ]ras leyes sobre el abuso de tener en el priorato cantidadades excesibas de dinero y le mandamos $\mathrm{q}[\mathrm{u}] \mathrm{e}$ además de las cantidades necesarias para los gastos ordinarios no retenga en su poder cantidad $\mathrm{q}[\mathrm{u}] \mathrm{e}$ exceda de seis mil reales, por más término $\mathrm{q}[\mathrm{u}] \mathrm{e}$ el de doze o quinze días en los que deberá, con toda diligencia, buscar medio de remitirlos a $\mathrm{n}$ [uest]ro monast[eri]o de Valla[doli]d y no proporcionándose ocasión lo habrá de poner interinam[ent]e en el depósito de n[uest]ro monast[eri]o de S[a]n Vicente de Monforte. Y, así mismo, con el objeto de moderar en lo posible los excesivos gastos de este priorato, renobando las acertadas probidencias dadas al intento por $\mathrm{n}$ [uest]ros antecesores, mandamos al $\mathrm{p}[$ adre] prior $\mathrm{q}[\mathrm{u}] \mathrm{e}$ sólo mantenga los criados y bestias absolutam[en]te necesarios para el servicio de esta casa y condución de sus rentas cuija (sic) recaudación y conducción estará a su cargo, como obligar por todos los medios a los foreros $\mathrm{q}[\mathrm{u}] \mathrm{e}$ por expresa condición en las escrit[ura]s forales deban poner las rentas en este priorato, a $\mathrm{q}[\mathrm{u}] \mathrm{e}$ así lo cumplan y para $\mathrm{q}[\mathrm{u}] \mathrm{e}$ las insinuadas probidencias sean más asequibles mandamos se continúe la costumbre de arrendar todos los diezmos mayores y menores de esta parroq[ui]a sacándolos a posturas públicas pudiendo reservarse el $\mathrm{p}$ [adre] prior la paja y algunas castañas verdes, como hasta aquí se practicó, para el consumo de la casa. Y en estos y otros contratos se estipule espresamente que los arrendatarios saquen por su cuenta copia de la escritura original para ponerla en el Archivo, en el que prohibimos al $\mathrm{p}$ [adre] prior, bajo precepto de santa obediencia, entrar monje o seglar alguno sin estar él presente o alguno de los pad[re]s curas conventuales de esta casa y por lo mucho $\mathrm{q}[\mathrm{u}] \mathrm{e}$ importa la conservación $\mathrm{y}$ mejor orden de los papeles y libros de $\mathrm{d}[\mathrm{ic}] \mathrm{ho}$ Archivo se recomienda al $\mathrm{p}$ [adre] prior y se le encarga estrecham[en]te no los extraiga de allí a su quarto sin grabísima necesidad, llebando quanto antes a ejecución el pensamiento de enquadernar los instrumentos y papeles sueltos, practicando igual diligencia con los ya enquadernados, pero $\mathrm{q}[\mathrm{u}] \mathrm{e}$ necesiten repararse y enquadernarse de nuevo y se recomienda igualm[en]te el cuidado de pasar a un libro con el nombre de apuntaciones para el gobierno de este priorato todas las qu]e se hallasen más propias para mejorarle, como que la existencia de sus rentas y regalías está librada únicam[en]te en los papeles de su Archivo y en el buen manejo y uso de ellos.

13.- Otrosí renobamos el mandato impuesto a los padres priores para $\mathrm{q}[\mathrm{u}] \mathrm{e}$ no se hagan partes formales y principales dueños en los contratos, diligencias judiciales, probisiones de piezas eclesiásticas y otros empleos de justicias, sino $\mathrm{q}[\mathrm{u}] \mathrm{e}$ en todo eso se arreglen puntualm[en]te a lo dispuesto en el capít[ul]o 23 de n[uest]ras Constituciones y den siempre por parte principal al $\mathrm{p}$ [adre] abad $\mathrm{y}$ monast[eri]o de Vallad[oli]d y en quanto a las regalías executen enteramente lo que tengamos a bien mandarles en la inteligencia de $\mathrm{q}[\mathrm{u}] \mathrm{e}$ no son más $\mathrm{q}[\mathrm{u}] \mathrm{e}$ unos meros administrad[ore]s y que todo el dominio de este priorato está totalmente refundido en el abad y monast[eri]o de Vallad[oli]d, todo lo qual les mandamos bajo las penas de pribación de sus oficios y otras a $\mathrm{nu}[$ estr]o arbitrio.

14.- Otrosí, mandamos al $\mathrm{p}$ [adre $]$ prior $\mathrm{q}[\mathrm{u}] \mathrm{e}$ que en las partidas de bara de centeno, trigo y vino sólo se descargue con arreglo a los $\mathrm{q}[\mathrm{u}] \mathrm{e}$, según las visitas anteriores y Libro de Quentas se han señalado años anteriopres, a saber sesenta y ocho faneg[a]s de centeno al año $\mathrm{p}$ [ar]a el gasto de casa. Para el de las caballerías de casa y huéspedes veinte y quatro faneg[a]s, para limosna noventa y quatro faneg[a]s con veinte y dos fanegas de trigo y ciento cinquenta y seis canados de vino $\mathrm{p}$ [ar]a el gasto de casa y huéspedes y diez y ocho ferr[ado]s de centeno $\mathrm{p}$ [ar]a la recolec[ció]n de rentas y hierba. Y en quanto a lo demás mandado por $\mathrm{n}$ [uest]ros antecesores, $\mathrm{q}[\mathrm{u}] \mathrm{e}$ no se hallare incompatible con lo $\mathrm{q}[\mathrm{u}]$ e dejamos ordenado, determinamos tenga cumplim[ien]to, según y como en otras $\mathrm{n}$ [uest]ras visitas se contiene. Y, finalmente, para $\mathrm{q}[\mathrm{u}] \mathrm{e}$ esta $\mathrm{n}$ [uest]ra visita tenga la debida obserbancia nombranmos por celadores de ella a los monjes conventuales más antiguos quienes si vieren $\mathrm{q}[\mathrm{u}] \mathrm{e}$ no se cumplen deberán 
amonestar al $\mathrm{p}$ [adre] prior y no bastando nos darán abiso para providenciar lo conveniente.

Fue leída esta n[uest]ra visita en presencia de $\mathrm{p}$ [adre] prior y demás mon[je]s de este priorato de S[a]n Salvador de Asma, a tres días del mes de sept[iembr]e de mil ochocientos diez y nueve.

Fr[ay] Andrés Castro, abad de S[a]n B[enit]o el R[ea]l (Rubricado).

$\mathrm{P}[\mathrm{o}] \mathrm{r}$ man[da]do de S[u] P[aternidad] M[uy] $\mathrm{R}$ [everen]da, Bern[ar]do de Sampedro (Rubricado).

\subsection{Visita en agosto de 1825}

Nós, el m[aest]ro, fr[ay] Fernando Seguín, $\mathrm{m}$ [aest]ro gen[era]l y abad de S[a]n Benito el $\mathrm{R}[\mathrm{ea}] \mathrm{l}$ de Vall[adoli]d, sus filiaciones, prioratos $\mathrm{y}$ anexos etc.

Habiendo visitado este priorato monasterial de S[a]n Salvador de Asma y su yglesia y visto la decencia con $\mathrm{q}[\mathrm{u}] \mathrm{e}$ esta el S[antísi]mo Sacramento, sagrados oleos, y la pila bautismal lo $\mathrm{q}[\mathrm{u}] \mathrm{e}$ nos pareció mandar para mayor servicio de N[uestro] Señor y aumento espiritual y temporal de esta casa habiéndolo consultado con el $\mathrm{p}$ [adre] prior es lo siguiente:

1.- Primeram[en]te encargamos la conciencia al $\mathrm{p}[$ adre] prior sobre $\mathrm{q}[\mathrm{u}] \mathrm{e}$ guarde $\mathrm{y}$ haga guardar los mandamientos de la ley de Dios y de la S[an]ta Madre Yglesia, la regla de N[uestro] P[adr]e S[a]n Benito, Constituciones, ceremonias y loables costumbres de $\mathrm{n}$ [uest]ra sagrada religión (cuanto sea posible con los respectivos empleos y ocupaciones fuera del claustro) y los particulares de este priorato con lo dispuesto en las visitas del y especialm[en]te en lo $\mathrm{q}[\mathrm{u}]$ e se ordena y manda en la presente.

2.- Otrosí, mandamos continue la loable costumbre de cantar todos los días la salve y la misa en los días principales como también $\mathrm{q}[\mathrm{u}] \mathrm{e}$ cuando buenam[en]te se pudiere se rece por unos y otros el oficio divino en el coro.

3.- Otrosí, encargamos al $\mathrm{p}$ [adre] prior y $\mathrm{p}$ [adres] curas la mayor decencia de sus yglesias haciendo arder continuam[en]te una lámpara delante del Santísimo Sacramento destinando para la compra del aceite los derechos de las sepulturas $\mathrm{q}[\mathrm{u}] \mathrm{e}$ se abran en las capillas mayores y algunas otras limosnas o fundaciones si las hubiese. $Y$ en atención a $\mathrm{q}[\mathrm{u}] \mathrm{e}$ por las circunstancias de los tiempos han percibido en estos años los p[adres] curas de Santiago da
Riva y Camporramiro, en lugar de la congrua señalada, todos los diezmos y emolum[en]tos de sus respectivos curatos, queda a su cargo la obligación, con la $\mathrm{q}[\mathrm{u}] \mathrm{e}$ estrecham[en]te les reconvenimos, suplir lo $\mathrm{q}[\mathrm{u}] \mathrm{e}$ falte y sea necesario para una luz continua en todo el año delante del S[antisi]mo Sacramento sin $\mathrm{q}[\mathrm{u}] \mathrm{e}$ el $\mathrm{p}$ [adre] prior tenga la obligación de darles las dos arrobas de aceite q[u]e hast'aquí se les daba a cada uno hasta tanto $\mathrm{q}[\mathrm{u}] \mathrm{e}$ se determine otra cosa a cerca de su congrua. Y así mismo reconvenimos al $\mathrm{p}$ [adre] prior y $\mathrm{p}$ [adres] curas con la precisa obligacion de procurar $\mathrm{q}[\mathrm{u}] \mathrm{e}$ todos sus feligreses vivan en el santo temor de Dios y estén instruidos en las obligaciones de christianos y para ello les encargamos y mandamos $\mathrm{q}[\mathrm{u}] \mathrm{e}$ en todos los dias festivos a la misa mayor les expliquen algún punto de doctrina christiana con el evanglelio en estilo sencillo y acomodado a la inteligencia de sus oyentes exhortándolos así mismo a las práctica de las virtudes y detestación de los vicios. Y además les prevenimos $\mathrm{q}[\mathrm{u}] \mathrm{e}$ anoten con toda puntualidad y en la mejor forma (cual lo pide la materia) en los respectivos libros de partidas de los Bautizados (con la razón o minuta de los confirmados) casados y dif[un]tos remitiéndonos precisam[en]te, cada año, certificación jurada de haberlo egecutado así y de no haber omitido partida alguna. Y procuren así mismo el más exacto cumplim[ien] to de los testam[en]tos y fundaciones piadosas desempeñando fielm[en] te la obligación de aplicar todos los días festivos la misa pro populo con otras dos $\mathrm{q}[\mathrm{u}] \mathrm{e}$ aplicarán, cada mes, cada uno de los tres curas, por las obligaciones de $\mathrm{n}$ [uest]ro monast[eri]o de Vall[adoli]d quedando a cargo del p[adre] prior el aplicar y celebrar todas las misas $\mathrm{q}[\mathrm{u}] \mathrm{e}$ tiene de obligación este priorato.

4.- Otrosí, por ser esenciales de n[uest]ro instituto los votos de clusura y pobreza para su mas puntual observancia, mandamos a los monjes conventuales de este monasterial priorato $\mathrm{q}[\mathrm{u}] \mathrm{e}$ en cumplim[ien] to de las Constituc[ione]s q[u]e de esto tratan y siguiendo en todo su tenor no salgan sin licencia expresa del $\mathrm{p}$ [adre] prior o presidente de la clausura determinada señaladam[en]te en la visita de 1786 y confirmada en las visitas posteriores, ni salga monge alguno solo, no siendo los $\mathrm{p}$ [adre]s curas para la precisa administración de su curato o para particular negocio de este priorato. Y bajo el precepto mandamos se continúe con el depósito común donde se pongan los peculios particulares conforme a ley y del 
no se pueda sacar cantidad alguna ni recibirse, ni gastarse sin licencia expresa del $\mathrm{p}$ [adre] prior o presidente en su ausencia. Y se previene seria y estrechamente al $\mathrm{p}[\mathrm{adr}] \mathrm{e}$ prior, $\mathrm{q}[\mathrm{u}] \mathrm{e}$ es $\mathrm{y}$ en adelante fuese, así por lo perteneciente a su persona, como a las licencias $\mathrm{q}[\mathrm{u}] \mathrm{e}$ a nombre $\mathrm{n}$ [uest]ro diese a los monges conventuales de este $\mathrm{n}[$ uest] ro priorato $\mathrm{q}[\mathrm{u}] \mathrm{e}$ no se crean por manera alguna con facultades para gastos extraordin[ario]s, así en el modo, como en la substancia, comprando o haciéndose con alajas o con cosas notablem[en]te costosas y menos necesarias como tampoco para regalar y hacer expresiones, aunq[u]e sea a los monges de la Congregac[i]ón $\mathrm{q}[\mathrm{u}] \mathrm{e}$ no sean muy moderadas.

5.- Otrosí, para precaver los graves perjuicios $\mathrm{q}[\mathrm{u}] \mathrm{e}$ de los enprestitos $\mathrm{q}[\mathrm{u}] \mathrm{e}$ hasta aquí se hiciesen se han experimentado, mandamos a $\mathrm{d}[\mathrm{ic}]$ ho $\mathrm{p}$ [adre] prior y monges conventuales no presten cantidad alguna $\mathrm{q}[\mathrm{u}] \mathrm{e}$ pase de sesenta $\mathrm{r}$ [eale]s sin recibir prenda $\mathrm{q}[\mathrm{u}] \mathrm{e}$ por lo menos exceda su valor una tercera parte del total del empréstito. Y así bien les prohivimos reciban y retengan en su poder, por vía de depósito, cantidades algunas, ni otros bienes pertenecientes a personas seculares, aunq[u]e sean criados de la Religión o actuales sirvientes del priorato; respecto a los cuales encargamos muy estrecham[en]te al $\mathrm{p}$ [adre] prior, sobre $\mathrm{q}[\mathrm{u}] \mathrm{e}$ le gravamos la conciencia y respectivam[en]te a los $\mathrm{p}$ [adre]s curas de afuera por lo perteneciente a los suyos, el cuidado de apuntar con toda claridad y precisión en su Libro de Caja la soldada en $\mathrm{q}[\mathrm{u}] \mathrm{e}$ los tienen ajustados y de habérseles satisfecho, como lo deben hacer siempre al fin de cada año, exponiéndole así en los memoriales $\mathrm{q}[\mathrm{u}] \mathrm{e}$ en las visitas deben presentarnos.

6.- Otrosí, mandamos al $\mathrm{p}[$ adre $]$ prior, $\mathrm{q}[\mathrm{u}] \mathrm{e}$ es o fuese, que todos los años por San Juan de junio forme y estienda las cuentas en los respectivos libros y remita copia de ellas a n[uest]ro monast[eri]o de Vall[adoli]d para trasladarlos al Libro de Prioratos. Y en el año de capítulo practique la misma diligencia antes de Pascua de Resurección expresando con toda individualidad, así a continuación del libro de Depósito en sus cuentas (después de ellas), como en las $\mathrm{q}[\mathrm{u}] \mathrm{e}$ remitan a Vall[adoli]d, el estado en $\mathrm{q}[\mathrm{u}] \mathrm{e}$ queda el priorato en aprovecham[ien]tos, prorrateos, pleitos particulares, gastos y demás ocurrente y en la misma forma $\mathrm{q}[\mathrm{u}] \mathrm{e}$ se extiende en los monasterios. $\mathrm{Y}$ cuando haya de entrar nuevo prior, entre éste y el que concluye, se formen cuentas finales y se haga formal entrega de todas las alhajas y ajuares propios de esta casa, las $q[u]$ e firmen uno y otro en su Libro Inventario quedando obligado el $\mathrm{q}[\mathrm{u}] \mathrm{e}$ sale a dejar servibles y usuales las alhajas y ajuares $\mathrm{q}[\mathrm{u}] \mathrm{e}$ recibió a su entrada, reponiendo las que se gasten y siendo responsable de las $\mathrm{q}[\mathrm{u}] \mathrm{e}$ falten respecto del inventario $\mathrm{q}[\mathrm{u}] \mathrm{e}$ recibió y por quanto de unos años a esta parte se ha omitido el cubrir las contrapartidas de los encabezados en sus respectivos libros, lo $\mathrm{q}[\mathrm{u}] \mathrm{e}$ ocasiona y trahe gravísimos daños y prejuicios y es contra ley y constitución, $\mathrm{q}[\mathrm{u}]$ e de esto trata, mandamos al $\mathrm{p}$ [adre] prior apunte en $\mathrm{d}[\mathrm{ic}]$ hos encabezados, con expresión de cada año, las partidas $\mathrm{q}[\mathrm{u}] \mathrm{e}$ se hayan cobrado, y en adelante se cobrasen, so pena de incurrir en la pena de privación de oficio, y las $\mathrm{q}[\mathrm{u}] \mathrm{e}$ según ley deben aplicarse a omisión tan perjudicial; y además mandamos $\mathrm{q}[\mathrm{u}] \mathrm{e}$ siempre $\mathrm{q}[\mathrm{u}] \mathrm{e}$ forme nuevo encabezado de rentas, $\mathrm{q}[\mathrm{u}] \mathrm{e}$ deberá ser por lo menos una vez al cuadrienio, se remitirá copia literal a dicho n[uest]ro monast[eri]o de Vall[adoli]d.

7.- Otrosí, por quanto a más del beneficio $\mathrm{q}[\mathrm{u}] \mathrm{e}$ resulta de la cobranza de laudemio es muy conducente a la mayor seguridad de las haciendas y facilidad de la cobranza de las rentas, mandamos al $\mathrm{p}$ [adre] prior averigüe con la posible solicitud las ventas q[u]e se hicieron de los bienes aforados y procure $\mathrm{q}[\mathrm{u}] \mathrm{e}$ los nuevos posedores paguen efectivam[en]te los laudemios y reconozcan el directo dominio.

8.- Otrosí, para precaver en lo sucesivo los enormes prejuicios $\mathrm{q}[\mathrm{u}] \mathrm{e}$ resultan de la dilación en las cobranzas de rentas, mandamos al $\mathrm{p}$ [adre] prior continue en las diligencias relativas a las cobranzas de atrasos e igualm[en]te en hacer efectivas todas las correspondientes al tiempo de su administración sin dejar partida alguna abierta, bien entendido $\mathrm{q}[\mathrm{u}] \mathrm{e}$ en las cuentas finales no se admitirá en descargo partida alguna de estas $\sin \mathrm{q}[\mathrm{u}] \mathrm{e}$ haga constar $\mathrm{q}[\mathrm{u}] \mathrm{e}$ practicó las diligencias judiciales y necesarias para su cobranza dirigiéndolas siempre $\mathrm{q}[\mathrm{u}] \mathrm{e}$ haya lugar contra los principales foreros y más alexados llevadores. Se le permite, no obstante, haga algunas prudentes condonaciones a los colonos indigentes $\mathrm{q}[\mathrm{u}] \mathrm{e}$ por pura necesidad hayan diferido o no cumplido las pagas y las cantidades causadas de $\mathrm{d}[\mathrm{ic}] \mathrm{has}$ cobranzas se lleven al Libro de Depósito con expresión de los valores corrientes en los años $\mathrm{q}[\mathrm{u}] \mathrm{e}$ se contrageron las deudas. 
9.- Otrosí, mandamos al $\mathrm{p}$ [adre] prior averigüe con toda diligencia $\mathrm{q}[\mathrm{u}] \mathrm{e}$ porciones de terreno se roturan y cultivan en el monte de $\mathrm{S}[\mathrm{a}] \mathrm{n}$ Sebastián y más terrenos propios de este priorato y cobre de todos los frutos $\mathrm{q}[\mathrm{u}] \mathrm{e}$ en ellos causaren, además del diezmo, un quinto íntegro por razón del directo dominio. Le mandamos continue en el cuidado de plantar árboles y de impedir por todas las vías, aún judiciales, el que se haga daño en los ya nacidos para asegurar de este modo la abundancia de leña $\mathrm{q}[\mathrm{u}] \mathrm{e}$ ha habido en este tiempo y $\mathrm{q}[\mathrm{u}] \mathrm{e}$ de presente va escaseando en extremo; como también que lleve adelante la importante obra de los prorrateos para aclarar por ese medio las rentas obscurecidas y no dar lugar a q[u]e éstas se obscurezcan.

10.- Otrosí, reconvenimos al $\mathrm{p}$ [adre] prior (y respectivam[en]te a los demás monjes conventuales) con lo $\mathrm{q}[\mathrm{u}] \mathrm{e}$ ordenan y disponen n[uest]ras Constituci[one]s sobre el abuso de tener en el priorato cantidades excesivas de dinero y le mandamos $\mathrm{q}[\mathrm{u}] \mathrm{e}$ además de las cantidades necesarias para los gastos ordinarios no tenga en su poder cantidad $\mathrm{q}[\mathrm{u}] \mathrm{e}$ exceda de seis mil r[eale]s por más término $\mathrm{q}[\mathrm{u}] \mathrm{e}$ el de quince días en los $\mathrm{q}[\mathrm{u}] \mathrm{e}$ deberá con toda diligencia buscar modo de remitirlo a n[uest]ro monast[eri]o de Vall[adoli]d y no proporcionándose ocasión lo habrá de poner interinam[en]te en el depósito de n[uest]ro monast[eri]o de S[a]n Vicente de Monforte $\mathrm{y}$, así mismo, con el objeto de moderar en lo posible los excesivos gastos de este priorato renovando las acertadas providencias dadas al efecto, mandamos al $\mathrm{p}$ [adre] prior $\mathrm{q}[\mathrm{u}] \mathrm{e}$ sólo mantenga los criados y bestias absolutam[en]te indispensables para el servicio de esta casa y conducción de rentas cuya recaudación esté a su cargo y no al de los foreros conforme a la condicion de las escrituras forales, para cuya mayor expedición mandamos se contiene en la costumbre de arrendar todos los diezmos mayores y menores como hast'aquí y en estos y otros contratos se estipule expresam[en]te $\mathrm{q}[\mathrm{u}] \mathrm{e}$ los llevadores saquen por su cuenta copia de la escritura original para ponerla en el archivo; y por lo que hace a los ferrados de castañas (con $\mathrm{q}[\mathrm{u}] \mathrm{e}$ se ha logrado acrecer el arriendo de los diezmos) y con atención a su menor percibo originado de la corta de varios castaños con motivo de la obra de casa, se pasan por ahora y se dejan (como hast'aquí la paja) para las necesidades del priorato.

11.- Otrosí, reconvenimos al $\mathrm{p}$ [adre] prior con lo $\mathrm{q}[\mathrm{u}] \mathrm{e}$ disponen $\mathrm{n}$ [uest]ras Leyes, lib[ro] 2, ca[pítulo] $24^{73}$, sobre $\mathrm{q}[\mathrm{u}] \mathrm{e}$ no se saque papel alguno del archivo sin dejar escrito en un cuaderno, $\mathrm{q}[\mathrm{u}] \mathrm{e}$ para este fin tendrá en el archivo, el instrumento $\mathrm{q}[\mathrm{u}] \mathrm{e}$ sacó, $\mathrm{q}[\mathrm{u}] \mathrm{e}$ día, mes y año y para que sin permitir a persona alguna entrar ni estar en el archivo sin hallarse él presente y por cuanto en el día, por razón de las circunstanci[a]s pasadas de n[uest]ra exclaustración, se hallan desordenados y confundidos todos los papeles e instrum[en]tos del archivo, encargamos estrecham[en]te al $\mathrm{p}$ [adre] prior cuide de ponerlos en orden y con aseo, cuanto antes sea posible, uniendo en legajos los instrum[en]tosy papeles sueltos $\mathrm{q}[\mathrm{u}] \mathrm{e}$ puedan encuadernarse haciéndolos forrar para su mayor duración, practicando igual diligencia con los encuadernados, pero $\mathrm{q}[\mathrm{u}] \mathrm{e}$ necesiten repararse y encuadernarse de nuevo. Del mismo modo se recomienda el cuidado de anotar en un Libro de Apuntaciones todas las advertencias $\mathrm{q}[\mathrm{u}] \mathrm{e}$ juzgue convenientes para el gobierno de este priorato, haciendo las diligencias para recobrar el $\mathrm{q}[\mathrm{u}] \mathrm{e}$ había con la laudable idea de mejorar en lo posible el estado de este priorato como $\mathrm{q}[\mathrm{u}] \mathrm{e}$ está librado únicam[en]te en los papeles de su archivo y en el buen manejo y uso de ellos.

12.- Otrosí, renovamos el mandato a los $\mathrm{p}$ [adres] priores para $\mathrm{q}[\mathrm{u}] \mathrm{e}$ no se hagan partes formales y principales dueños en los contratos, diligencias judiciales, provisiones de piezas ec[lesiásti]cas y otros empleos de justicia, sino $\mathrm{q}[\mathrm{u}] \mathrm{e}$ en todo esto se arreglen puntualm[en]te a lo dispuesto en el capítulo 23 de nuestras Constituciones ${ }^{74} \mathrm{y}$ den siempre \por/ parte principal al p[adre] abad y monast[eri]o de Vall[adoli]d en quien reside todo el dominio de este priorato sin exceder por manera alguna del poder instrucc[i]ón y órdenes $\mathrm{q}[\mathrm{u}] \mathrm{e}$ se le hubiesen dado y se le dieren en los lances particulares $\mathrm{q}[\mathrm{u}] \mathrm{e}$ deberán consultar.

73 Cf. las Constituciones de la Congregación de Nuestro Glorioso Padre San Benito de España e Inglaterra (1706: 237-240), donde prácticamente está copiado todo cuanto se indica en la visita. Usamos esta edición por ser la más completa.

74 Ibid. 90-92 (donde se habla de las prerrogativas y obligaciones del General de la Congregación). 
13.- Otrosí, por lo $\mathrm{q}[\mathrm{u}] \mathrm{e}$ respecta a los $\mathrm{p}$ [adre]s curas de Camporramiro y Santiago da Riva q[u]e se hallan residiendo de algún tiempo a esta parte en sus respectivas feligresías, les mandamos $\mathrm{q}[\mathrm{u}] \mathrm{e}$ asistan continuamente en ellas $\sin \mathrm{q}[\mathrm{u}] \mathrm{e}$ puedan pernoctar fuera, sin licencia de $\mathrm{p}$ [adre] prior de este priorato, como individuos y conventuales q[u]e son d'él; y el $\mathrm{p}$ [adre] prior a quien facultamos para darla, de tres o cuatro días a distancia de tres o cuatro leguas, se arreglará en cuanto a uno y a otro a lo $\mathrm{q}[\mathrm{u}] \mathrm{e}$ disponen $\mathrm{n}[\mathrm{uest}] \mathrm{ras}$ leyes en el particular y la práctica común y autorizada de $n$ [uest]ro monast[eri]o.

14.- Otrosí, para ocurrir a los inconvenientes $\mathrm{q}[\mathrm{u}] \mathrm{e}$ pueden sobrevenir en lo sucesivo a cerca de la libertad y entero dominio de este priorato, así en las casas como en los huertos $\mathrm{q}[\mathrm{u}] \mathrm{e}$ se han hecho y comprado por este priorato (como todo consta de las escrituras y demás papeles fehacientes) y en las $\mathrm{q}[\mathrm{u}] \mathrm{e}$ viven y disfrutan respectivam[en]te $\mathrm{d}[\mathrm{ic}]$ hos $\mathrm{p}$ [adre]s curas de Camporramiro y santiago da Riva, encargamos estrecham[en]te al $\mathrm{p}$ [adre] prior $\mathrm{q}[\mathrm{u}] \mathrm{e}$ pase al archivo y guarde el papel de obligación formal y autorizado en cuya virtud y poniendo por cabeza la razón de la respectiva individual pertenencia de $\mathrm{d}[\mathrm{ic}]$ has fincas, cada uno de $\mathrm{d}[\mathrm{ic}]$ hos padres curas se obligue a pagar, con separación por casa y huerto, la cantidad anual de centeno en $\mathrm{q}[\mathrm{u}] \mathrm{e}$ a juicio de perito inteligente se declare poder estimarse en un arriendo equitativo las sobre $\mathrm{d}[\mathrm{ic}]$ has fincas y el $\mathrm{p}$ [adre] prior las tomará en cargo en su Libro de Centeno. Más, y para que esta providencia no pase perjuicio a $\mathrm{d}[\mathrm{ic}]$ hos $\mathrm{p}[$ adre $] \mathrm{s}$ curas, el p[adre] prior les abonará, desde luego, la misma cantidad $\mathrm{q}[\mathrm{u}] \mathrm{e}$ se les cargase y él se encargará de ella en la expresión de $\mathrm{q}[\mathrm{u}] \mathrm{e}$ se abona la tal cantidad de centeno para hacerles así nada gravosa la paga de su arriendo.

15.- Otrosí, y porq[u]e cediendo a las imperiosas circunstancias de los tiempos hemos venido en alargar al sacerdote secular $\mathrm{q}[\mathrm{u}] \mathrm{e}$ con nombramiento de este priorato egerce el ministerio de vicario nutual ${ }^{75}$ en $\mathrm{n}$ [uest]ra feligresía de Pereira, todos los diezmos de ella, se proviene a los $\mathrm{p}[$ adre]s priores $\mathrm{q}[\mathrm{u}] \mathrm{e}$ la pensión debida al s[eñ]or deán de Lugo por los frutos de $d[$ ic] ha vicaría, y afecta a ellos, se debe pagar, y pagar por el mismo vicario $\mathrm{q}[\mathrm{u}] \mathrm{e}$ tiene hecho en esta razón allanam[ien]to judicial ante el $\mathrm{s}[\mathrm{eñ}]$ or deán, $\mathrm{p}[\mathrm{adr}] \mathrm{e}$ prior actual y otras personas; se previene igualm[en]te $\mathrm{q}[\mathrm{u}] \mathrm{e}$ pagando, como paga, este priorato el subsidio correspond[ien]te al total de sus rentas y frutos, en cuyo globo se incluyen los diezmos de Pereira, se debe seguir cobrando de dicho vicario la parte de subsidio correspond[ien]te a los diezmos q[u]e lleva para indemnizar así a este priorato de lo $\mathrm{q}[\mathrm{u}] \mathrm{e}$ paga en el todo de la contribución correspondiente a los frutos de Pereira.

16.- Otrosí, mandamos al $\mathrm{p}[$ adre $]$ prior $\mathrm{q}[\mathrm{u}] \mathrm{e}$ en las partidas de data de centeno, trigo y vino sólo descargue con arreglo a lo q[u]e, según las visitas anteriores y Libro de Cuentas, le han señalado mis antecesotres, a saber: 68 fan[ega]s de centeno etc. Y por quanto los $\mathrm{p}[\mathrm{adre}] \mathrm{s}$ curas de Camporramiro y Santiago da Riva, en lugar de la congrua señalada en la visita de 1806, siguen percibiendo todos los diezmos y emolumentos de sus respectivos curatos hasta que por Nos o n[uest]ros sucesores se determine de satisfacer todas las cargas y pensiones anexas a $\mathrm{d}[\mathrm{ic}]$ hos curatos, inclusa la del subsidio, de sus limossnas a los pobres de sus parroquias y la de contribuir a este priorato el $\mathrm{p}$ [adr]e cura de Santiago da Riva con quince canados de vino y el de Camporramiro con cinco canados los cuales canados llevará el $\mathrm{p}$ [adre] prior al Libro de Bodega y se hará cargo de ellos.

17.- Otrosí, hallándose, como se halla, con muro doble la dehesa $\mathrm{q}[\mathrm{u}] \mathrm{e}$ llaman do Coto $<$ dos $>\operatorname{Merlos}^{76}$ para uso privativo de este monast[eri]o en su leña y todos los demás esquilmos, mandamos al $\mathrm{p}$ [adre] prior continue promoviendo todas las mejoras de $\mathrm{q}[\mathrm{u}] \mathrm{e}$ sea susceptible y $\mathrm{q}[\mathrm{u}] \mathrm{e}$ por ningún acontecim[ien] to permita se introduzca en ella ganado alguno y

75 "Ad nutum" literalmente significa "a la menor seña"; en este caso, mandato que expresa y manifiesta la voluntad y orden de otro, pues el vicario del que se habla estaba nombrado por el monasterio.

76 Hemos incluido "dos" dado que en otra documentación más antigua y moderna aparece siempre como "Coto dos Merlos". Está a continuación de los actuales prados que pertenecieron al monasterio y, efectivamente, el muro tiene en algunos tramos una especie de cubos como contrafuertes de sujección. Debió de ser un lugar muy estimado, pues todas las aguas que llegaban al monasterio pasaban por distintos lugares de este coto. Por eso, en algún momento el monasterio tiene pleito con los vecinos de Quintela por actuar sobre las aguas vertientes de este coto. 
así en ésta, como en la de $\mathrm{B} \backslash \mathrm{a} / \mathrm{razal}^{77}$, se prohibe estrecham[en]te el cortar por el pié robles $\mathrm{q}[\mathrm{u}] \mathrm{e}$ aún pudieren dar fruto.

18.- Otrosí, en atención a $\mathrm{q}[\mathrm{u}] \mathrm{e}$ así el inventario de alhajas y ornamentos de la yglesia y sacristía con los gastos ordinarios y extraordin[ario]s q[u]e se hacen en ella parece corresponder al Libro de Misas como a su propio lugar, encargamos al $\mathrm{p}$ [adre] prior $\mathrm{q}[\mathrm{u}] \mathrm{e}$ es, $\mathrm{y}$ en adelante fuere, ponga en $\mathrm{d}[\mathrm{ic}]$ ho libro los renglones relativos a yglesía y sacristía en los mismos términos $\mathrm{q}[\mathrm{u}] \mathrm{e}$ hast ahora.

$\mathrm{Y}$, finalm[en]te, para $\mathrm{q}[\mathrm{u}] \mathrm{e}$ esta $\mathrm{n}[$ uest]ra visita tenga el debido cumplim[ien]to, nombramos por celadores de ella a los dos monjes conventuales más antiguos, quienes si vieren $\mathrm{q}[\mathrm{u}] \mathrm{e}$ no se cumple deberán amonestar al $\mathrm{p}$ [adre] prior y no bastando nos darán aviso para providenciar lo conveniente.

Fue leida esta $n$ [uest]ra visita en presencia del $\mathrm{p}$ [adre] prior y demás monjes en este priorato de S[an] Salvador de Asma a Veinte y $(. . .)^{78}$ de agosto del año de mil ochocientos veinte y cinco.

Fr[ay Fernando Seguin, abad de S[a]n B[eni] to el R[ea]l.

Por mandado de $\mathrm{S}[\mathrm{u}] \mathrm{P}$ [aternidad] $\mathrm{R}$ [everen]d[ísim]a, Fr[ay] Antonio Villa, s[ecreta]rio.

\subsection{Visita en agosto de 1829}

Nos el m[aest]ro fr[ay] Pedro Garza, M[aest]ro gen[era]l y abad de San Benito el R[ea]l de Vall[adoli]d, sus filiaciones, prior[ato]s, anejos, etc. Haviendo visitado este priorato monaster[ia]l de S[a]n Salvador de Asma, su yglesia, etc. Y visto la decencia con $\mathrm{q}[\mathrm{u}] \mathrm{e}$ está el S[antísi]mo Sacram[en]to, sagra[do]s oleos y pila bautysmal, lo q[u]e nos pareció mandar para maior servicio de $\mathrm{n}$ [uest]ro S[eñ]or y aumento espiritual y temporal de esta casa, haviéndolo consultado con el $\mathrm{p}$ [adre] prior, es lo siguiente:
1.- primeram[en]te encargamos la conciencia al $\mathrm{p}$ [adre] prior sobre que guarde y haga guardar los mandam[ien]tos de la ley de Dios, de la Santa Madre Yglesia, la regla de n[uest]ro $\mathrm{P}$ [adre] S[a]n Benito, las Constituciones, ceremonias y loables costumbres de n[uest]ra sagrada religión, cuanto sea compatible con los respectivos empleos y ocupaciones fuera del claustro y las particulares de este priorato con lo dispuesto en las visitas de él y especialm[en]te en lo $\mathrm{q}[\mathrm{u}] \mathrm{e}$ se ordena y manda en la presente.

2.- Otrosí, mandamos continue la loable costumbre de cantar todos los días la salve y la misa en las fiestas princip[al] es; como tamb[ié]n $\mathrm{q}[\mathrm{u}] \mathrm{e}$, cuando buenam[en]se te pudiere, se reze por unos o por otros el Oficio Divino en el choro.

3.- Otrosy, encargamos al $\mathrm{p}$ [adre] prior $\mathrm{y}$ a los $\mathrm{p}$ [adre]s curas la maior dezencia de sus yglesias haziendo arder continuam[en]te una lámpara delante del S[antísi]mo Sacramento, destinando para la compra del azeite los derechos de las sepulturas $\mathrm{q}[\mathrm{u}] \mathrm{e}$ se abran en las capilllas maiores y algunas limosnas o fundaciones sy las huviese. Y en atención a q[u]e, por las circunstancias de los tiempos, han percibido en estos años los $\mathrm{p}$ [adre]s curas de Santiago da Riva y Campo Ramiro ${ }^{79}$ en lugar de la congrua señalada todos los diezmos y emulumentos de sus respectivos curatos, queda a su cargo y obligación con la q[u]e está estrechamente les reconvenimos suplir lo $\mathrm{q}[\mathrm{u}] \mathrm{e}$ falte y sea necesario para una luz continua en todo el año delante del S[antísi]mo Sacramento $\sin \mathrm{q}[\mathrm{u}] \mathrm{e}$ el $\mathrm{p}$ [adre] prior tenga obligación de darles las dos arrobas de azeite $\mathrm{q}[\mathrm{u}] \mathrm{e}$ hasta aquí se les daba a cada uno hasta tanto $\mathrm{q}[\mathrm{u}] \mathrm{e}$ se determine otra cosa a cerca de su congrua. $\mathrm{Y}$, así mismo, reconvenimos al $\mathrm{p}$ [adre] prior y $\mathrm{p}$ [adre]s curas con la precisa obligación de procurar $\mathrm{q}[\mathrm{u}] \mathrm{e}$ todos sus feligreses vivan en el santo temor de Dios y estén instruidos en las obligaciones de christianos, y para ello les encargamos $\mathrm{q}[\mathrm{u}] \mathrm{e}$, en todos los días festivos,

77 Era una gran extensión plantada de robles posiblemente de siglos y otros centenarios que se arrancaron, estando en perfecto estado después de quemar el lugar para pastos, dada la necesidad de hierva demandada por los establos circundantes. Estaba situada en la parroquia de San Salvador de Vilaúxe entre el regato de Camporramiro, también llamado regato da Líncora y regato da Barxa, y el lugar de Mundin.

78 Falta el guarismo de las unidades. Como ya se ha dicho, quizás el texto de la visita estaba escrito con anterioridad a la lectura y una vez leído, en ese instante, se pondría la fecha completa, pese a que aquí se ha omitido u olvidado.

79 Escribe separando ambas palabras. Nosotros en a tención al texto lo dejamos separado, aunque la grafía actual es Camporramiro (Nomenclátor de Galicia. Lugo, 2000: 44), al igual que en los numerosos documentos medievales que hablan de esta parroquia. 
a la misa maior, les expliquen algún punto de doctrina christiana con el evangelio en estilo senzillo y acomodado a la ynteligencia de sus oyentes exortándolos, así mismo, a la práctica de las virtudes y detestación de los vicios. Y además les prevenimos $\mathrm{q}[\mathrm{u}] \mathrm{e}$ anoten con toda puntualidad y en la maior forma (qual lo pide la materia), en los respectivos libros, las partidas de los bautizados con la razón o minuta de los confirmados, casados y difuntos remitiéndonos precisam[en]te cada año certificación jurada de haverlo executado asy y de no haver omitido partida alguna y procurar así mismo el más exacto cumplimiento de los testamentos y fundaciones piadosas desempeñando fielmente la obligación de aplicar todos los días festivos la misa pro populo, con otras dos $\mathrm{q}[\mathrm{u}] \mathrm{e}$ aplicarán cada mes cada unos de los s[eñor]es curas por las obligaciones de nuestro monasterio de Vall[adoli]d quedando a cargo del $\mathrm{p}$ [adre] prior el aplicar y celebrar todas las misas $\mathrm{q}[\mathrm{u}] \mathrm{e}$ tiene de obligación este priorato.

4.- Otrosy, por ser esenciales de n[uest]ro instituto los votos de clausura y pobreza para su más puntual observancia, mandamos a los monges conventuales de este priorato $\mathrm{q}[\mathrm{u}] \mathrm{e}$ en cumplimiento de las constituciones, $\mathrm{q}[\mathrm{u}] \mathrm{e}$ de esto tratan, y siguiendo en todo su tenor no salgan sin licencia expresa del $\mathrm{p}$ [adre] prior o presidente de la clausura determinada señaladamente en la visita de 1786 y confirmada en las visitas posteriores, ny salga un monje solo, no siendo los p[adr]es curas para la precisa adminsitración de sus curatos o para particular negocio de este priorato. Y, bajo el mismo precepto, mandamos se continue con el depósito común donde se pongan los peculios particulares conforme a ley y de él no se pueda sacar cantidad alguna, recibirse ny gastarse sin liz[enci]a expresa del $\mathrm{p}$ [adre] prior o $\mathrm{p}$ [adre] presidente en su ausencia. Y se previene seria $\mathrm{y}$ estrechamente al $\mathrm{p}[$ adre $]$ prior, $\mathrm{q}[\mathrm{u}] \mathrm{e}$ es o en adelante fuere, asy por lo perteneciente a su priorato, como a las licencias q[u]e a n[uest]ro nombre tiene, a los monges conventu[ale]s de este priorato $\mathrm{q}[\mathrm{u}] \mathrm{e}$ no se crean, por manera alguna, con facultades para gastos extraordinarios, así en el modo como en la substancia, comprando o haziéndose con alhajas o cosas notablem[en]te costosas y menos necesarias, como tampoco para regalar y hazer expresiones, aunque sea a monjes de la congregación $\mathrm{q}[\mathrm{u}] \mathrm{e}$ no sean muy moderados.
5.- Otrosy, precaver los grandes perjuicios $\mathrm{q}[\mathrm{u}] \mathrm{e}$ de los emprestitos $\mathrm{q}[\mathrm{u}] \mathrm{e}$ hasta aquy se hizieron, se han experimentado, mandamos al $\mathrm{p}$ [adre] prior y monjes conventuales no presten cantidad alg[un]a $\mathrm{q}[\mathrm{u}] \mathrm{e}$ pase de sesenta reales sin recibir prenda $\mathrm{q}[\mathrm{u}] \mathrm{e}$, por lo menos, exceda su valor a una terzera parte del total del emprestito. Y, asy mismo les prohibimos reciban y retengan en su poder por vía de depósito cantidades algunas ny otros bienes pertenecientes a personas seculares, aunq[u]e sean criados de la Religión o actuales sirvientes del priorato, respecto de los cuales encargamos muy estrechamente al $\mathrm{p}$ [adre] prior, sobre $\mathrm{q}[\mathrm{u}] \mathrm{e}$ le gravamos la conciencia, y respectivam[en]te a los p[adre]s curas de Santiago da Riva y Campo Ramiro por lo perteneciente a los suios el cuidado de apuntar con toda claridad y precisión en su Libro de Caja la soldada en $\mathrm{q}[\mathrm{u}] \mathrm{e}$ los tiene ajustados y de haverselas satisfecho como lo deben hazer siempre al fin del año en todos ellos exponiendolo asy en los memoriales $\mathrm{q}[\mathrm{u}] \mathrm{e}$ en las visitas deben presentarnos.

6.- Otrosy, mandamos a $\mathrm{p}[$ adre $]$ prior, $\mathrm{q}[\mathrm{u}] \mathrm{e}$ es o fuere, $\mathrm{q}[\mathrm{u}] \mathrm{e}$ todos los años, por San Juan de junio, forme y extienda las cuentas en los respectivos libros y remita copia de ellas a n[uest]ro monasterio de Vall[adoli]d para trasladarlas al Libro de Prioratos, y en el año de capítulo practique la misma diligencia antes de Pascua de Resurección expresando con toda individualidad, asy a cointinuación de las cuentas del Libro Depósito, como en las q[u]e se remitan a Valladolid, el estado en $\mathrm{q}[\mathrm{u}] \mathrm{e}$ queda el priorato en aprovechamientos, prorrateos, pleytos particulares, gastos y demás ocurrentes $\mathrm{y}$, en la misma forma, $\mathrm{q}[\mathrm{u}] \mathrm{e}$ se extiende en los monasterios y cuando haya de entrar de nuevo prior entre éste y el $\mathrm{q}[\mathrm{u}] \mathrm{e}$ cuncluie se formen cuentas finales y se haga formal entrega de todas las alajas y ajuares proprios de esta casa, los que firmen uno y otro en su Libro Ynventario, quedando obligado el $\mathrm{q}[\mathrm{u}] \mathrm{e}$ sale a dejar servibles y usuales las alajas y axuares $\mathrm{q}[\mathrm{u}] \mathrm{e}$ recibió a su entrada, reponiendo las $\mathrm{q}[\mathrm{u}] \mathrm{e}$ se gasten y siendo responsable de las $\mathrm{q}[\mathrm{u}] \mathrm{e}$ falten respecto del ynventario $\mathrm{q}[\mathrm{u}] \mathrm{e}$ recibió y por cuanto de algunos años a esta parte se ha omitido el cubrir las contrapartidas de los encavezados en sus respectivos libros lo que ocasiona y trahe gravísimos daños y perjuicios y es contra la ley y costitución $\mathrm{q}[\mathrm{u}] \mathrm{e}$ de esto trata, mandamos al $\mathrm{p}$ [adre] prior apunte en dichos encavezados, con expresión de cada año, las partidas $\mathrm{q}[\mathrm{u}] \mathrm{e}$ se haian cobrado y en adelante se cobraren, so 
pena de incurrir en la pena de privación de oficio y las que según ley deben aplicarse a omisión tan perjudicial; $\mathrm{y}$, aunque mandamos $\mathrm{q}[\mathrm{u}] \mathrm{e}$, siempre que se firme nuevo encavezado de rentas $\mathrm{q}[\mathrm{u}] \mathrm{e}$ deberá ser, por lo menos una vez al cuadrienio, se remitirá copia literal a $\mathrm{n}$ [uest]ro monasterio de Vall[adoli]d.

7.- Otrosy, por cuanto más del beneficio $\mathrm{q}[\mathrm{u}]$ e resulta de cobranza de laudemios es muy conduzente a la seguridad de la haziendas y facilidad de la cobranza de rentas, mandamos al $\mathrm{p}$ [adre] prior averigüe con la posible voluntad las ventas $\mathrm{q}[\mathrm{u}] \mathrm{e}$ se hizieron de los bienes aforados y procure $\mathrm{q}[\mathrm{u}] \mathrm{e}$ los nuevos poseedores paguen efectivam[en]te los laudemios y reconozcan el directo dominio.

8.- Otrosy, para precaver en lo sucesivo los enormes perjuicios $\mathrm{q}[\mathrm{u}] \mathrm{e}$ resultan de la dilación en las cobranzas de rentas, mandamos al $\mathrm{p}$ [adre] prior continue en las diligencias relativas a las cobranzas de atrasos e ygualm[en]te en hacer efectivas todas las correspondientes al tiempo de su administración sin dejar partida alguna abierta; bien entendido que en las cuentas finales no se le admitirá en descargo partida alguna de estas $\sin \mathrm{q}[\mathrm{u}[\mathrm{e}$ haga constar $\mathrm{q}[\mathrm{u}] \mathrm{e}$ practicó las diligencias judiciales y necesarias para su cobranza dirigiéndolas, siempre $\mathrm{q}[\mathrm{u}] \mathrm{e}$ haya lugar, contra los principales foreros y más avonados llevadores; se le permite nobstante haga algunas prudentes condonaciones a los colonos yndigentes $\mathrm{q}[\mathrm{u}] \mathrm{e}$ por pura necesidad hayan diferido, o no cumplido las pagas, y las cantidades causadas de dichas cobranzas las lleven al Libro de Depósito con expresión de $\mathrm{q}$ [ue] los valores corrientes en los años que se contrajeron las deudas.

9.- Otrosy, mandamos al $\mathrm{p}$ [adre] prior averigüe con toda diligencia que porciónes de terreno se roturan y cultivan en el monte de $\mathrm{S}[\mathrm{a}] \mathrm{n}$ Sebastián y más terrenos propios de este priorato y cobre de todos los frutos $\mathrm{q}[\mathrm{u}] \mathrm{e}$ en ellos se causaren ad[e]más del diezmo, un quinto íntegro por razón del directo dominio y estas partidas las anote y tome en cargo en los libros q[u]e correspondan y, así mismo, le mandamos continúe en el cuiddo de plantar árboles y de impedir por todas las vías, aún judiciales, el $\mathrm{q}[\mathrm{u}] \mathrm{e}$ se haga daño en los ya nazidos para asegurar de este modo la abundancia de leña que havido en otro tiempo y q[u]e de presente va escaseando en extremo; como también el q[u]e lleve adelante la importante obra de los prorrateos para allanar por este medio las rentas obscurecidas y no dar lugar a que otras también se obscurezcan.

10.- Otrosy, reconvenimos al $\mathrm{p}$ [adre] prior, e igualm[en]te a los tres $\mathrm{p}[$ adre]s curas, con lo $\mathrm{q}[\mathrm{u}] \mathrm{e}$ ordenan y disponen $\mathrm{n}[$ uest]ras Constituciones sobre el abuso de tener en su poder cantidades excesivas de dinero, y les mandamos $\mathrm{q}[\mathrm{u}] \mathrm{e}$, además de las cantidades necesarias para los gastos ordinarios de sus casas, no tengan en su poder otras, las que havran de poner en el depósito común de nuestro monasterio de S[a]n Vizente de Monforte, como otro cualqui[er]a monge convent[ua]l de aq[ue]1 monasterio recogiéndose la llave de su cajón; lo cual ejecutarán con intervención y aprobación del $\mathrm{p}$ [adre] abad o $\mathrm{p}$ [adre] presidente del mismo monasterio dándole parte cuando con este motivo haia de abrirse o cerrarse el depósito, previniendo al $\mathrm{p}$ [adre] prior no tenga en su poder cantidad $\mathrm{q}[\mathrm{u}] \mathrm{e}$ exceda de seis mil r[eale]s por más tiempo que el de quinze días en los que deberá con toda diligencia buscar medio de remitirlos a nuestro monasterio de Valladolid y no proporcionándose ocasión lo avrá de poner interinamente en el depósito de $\mathrm{n}[$ uest]ro monast[eri]o de S[a]n Viz[en]te de Monforte, como tamb[ié]n q[u]e hagan las diligencias para cobrar las deudas $\mathrm{q}[\mathrm{u}] \mathrm{e}$ tengan a su favor o a lo menos hagan y preciven a los deudores a $\mathrm{q}[\mathrm{u}] \mathrm{e}$ les entreguen obligaciones en papel sellado y de manera que hagan fee en los tribunales, principalm[en]te al tiempo de concluir sus oficios y liquidar cuentas con dichos deudores.

11.- Otrosy, con el objeto se moderaran en lo posible los excesivos gastos de este priorato, renovando las acertadas providencias dadas a este efecto, mandamos al $\mathrm{p}[$ adre $]$ prior $\mathrm{q}[\mathrm{u}] \mathrm{e}$ sólo mantenga los criados y bestias absolutamente indispensables $\mathrm{p}$ [ar]a el servicio de esta casa y conducción de rentas cuia recaudación esté a su cargo y no al de los foreros conforme a la condición de las escrituras forales, para cuia maior expedición mandamos se continue en la costumbre de arrendar los diezmos miores y menores como hasta aquy y, en estos y otros tales contratos, se extipule expresamente que los llevadores saquen por su cuenta copia de la escritura original $\mathrm{p}$ [ar]a ponerla en el archivo y por lo $\mathrm{q}[\mathrm{u}] \mathrm{e}$ haze a los ferrados de castañas (con $\mathrm{q}[\mathrm{u}]$ e se ha logrado acrezer el arriendo de los diezmos) y con atención a su menor percivo originado de la corta de varios castaños con motivo de la obra de casa se pasan por ahora y 
se dejan como hasta aquy la paja para las necesidades y consumo del priorato.

12.- Otrosy, reconvenimos al $\mathrm{p}$ [adre] prior con lo q[u]e disponen $\mathrm{n}$ [uest]ras leyes al capítulo 24 , libro $2^{\circ}$ sobre $\mathrm{q}[\mathrm{u}] \mathrm{e}$ no saque papel alguno del archivo sin dejar escrito en un cuaderno, q[u]e p[ar]a el fin tendrá en el archivo, el ynstrum[en]to $\mathrm{q}[\mathrm{u}] \mathrm{e}$ saca, el día, mes y año y para $\mathrm{q}[\mathrm{u}] \mathrm{e}$ fin lo saca, sin permitir a persona alguna entrar y estar en el archivo sin hallarse él presente. Y por cuanto en el día, por razón de las circunstancias pasadas de n[uest]ra exclaustración, se hallan desordenados y confundidos todos los papeles e ynstrumentos del $\operatorname{archivo~}^{80}$, encargamos extrecham[en]te al $\mathrm{p}$ [adre] prior cuide de ponerlos en orden y con aseo, cuanto antes sea posible, uniendo en legajos los ynstrum[en]tos y papeles sueltos, $\mathrm{q}[\mathrm{u}] \mathrm{e}$ puedan encuadernarse haziéndolos forrar para su maior duración, practicando ygual diligencia con los ya encuadernados, pero $\mathrm{q}[\mathrm{u}] \mathrm{e}$ necesiten repararse y encuadernarse del mismo modo de nuevo. Asy mismo se recomienda el cuidado de anotar en un Libro de Apuntación todas las advertencias $\mathrm{q}[\mathrm{u}] \mathrm{e}$ juzgue convenientes para el govierno de este priorato, haziendo las diligencias para recobrar el $\mathrm{q}[\mathrm{u}] \mathrm{e}$ ya hazia con laudable ydea de mejorar en lo posible el estado de este priorato, como q[u]e está librado unicam[en]te en los papeles de su archivo y en el buen manejo y uso de ellos.

13.- Otrosy, renovamos el mandato impuesto a los $\mathrm{p}$ [adres] priores para $\mathrm{q}[\mathrm{u}] \mathrm{e}$ no se hagan partes formales y principales dueños en los contratos, diligencias judiciales,provisiones de piezas eclesiásticas y otros empleos de justicia, sino $\mathrm{q}[\mathrm{u}] \mathrm{e}$ en todo esto se arreglen particularm[en]te a lo dispuesto en el cap[ítul]o 23 de $n$ [uest]ras Constituciones y den siempre por parte principal al $\mathrm{p}$ [adre] abad y monasterio de Valladolid, en quien reside todo el dominio de este priorato sin exceder por manera alguna del poder, ynstrucción, órdenes $\mathrm{q}[\mathrm{u}] \mathrm{e}$ se le huvieren dado y se le dieren en los lanzes particulares $\mathrm{q}[\mathrm{u}] \mathrm{e}$ ocurran y deberan consultar.

14.- Otrosy, por lo que respeta a los $\mathrm{p}$ [adr]es curas de Campo Ramiro y Santiago da Riba, $\mathrm{q}[\mathrm{u}] \mathrm{e}$ se hallan residiendo, de algún tiempo a esta parte, en sus respectivas feligresías, les mandamos $\mathrm{q}[\mathrm{u}] \mathrm{e}$ existan continuamente a en ellas $\sin \mathrm{q}[\mathrm{u}] \mathrm{e}$ puedan pernoctar fuera sin licencia del $\mathrm{p}$ [adre] prior de este priorato, como yndividuos y conventuales $\mathrm{q}[\mathrm{u}] \mathrm{e}$ son de él, y el $\mathrm{p}$ [adre] prior, a quien facultamos para dársela por tres o cuatro días y a distancia de tres o cuatro leguas, se arreglará en cuanto a uno y otro a lo dispuesto en n[uest]ras leyes en el particular y a la practica común y autorizada de $n$ [uest]ro monasterio.

15.- Otrosy, para ocurrir a los ynconvenientes que pueden sobrevenir en lo suzesivo a cerca de la libertad y entero dominio de este priorato asy en las casas como en los huertos $\mathrm{q}[\mathrm{u}] \mathrm{e}$ se han hecho y comprado por este priorato (como todo consta de las escrituras y papeles fee hazientes y en las $\mathrm{q}[\mathrm{u}] \mathrm{e}$ viven y disfrutan respectivamente $\mathrm{d}[\mathrm{ic}]$ hos $\mathrm{p}[$ adre $] \mathrm{s}$ curas de Santiago da Riva y Campo Ramiro, encargamos estrecham[en]te al $\mathrm{p}[$ adre] prior $\mathrm{q}[\mathrm{u}] \mathrm{e}$ pase al archivo y guarde el papel de obligación formal y autorizado en cuya virtud y poniendo por cabeza la razón de respectiva individual pertenencia de $\mathrm{d}[\mathrm{ic}]$ has fincas, cada uno de $\mathrm{d}[\mathrm{ic}]$ hos $\mathrm{p}[\mathrm{adr}] \mathrm{es}$ curas se obligue a pagar con separación por casa y huerto la cantidad annual de zenteno en $\mathrm{q}[\mathrm{u}] \mathrm{e}$, a juicio de perito inteligente, se declare poder estimarse en un $\operatorname{arr}[$ ien] do equitativo las sobre $\mathrm{d}[$ ic] has fincas y el $\mathrm{p}$ [adre] prior las tomará en cargo en su Libro de Zenteno. (...) y porq[u]e esta provid[enci]a no pare en perjuicio de $\mathrm{d}[\mathrm{ic}]$ hos $\mathrm{p}$ [adre $] \mathrm{s}$ curas, el $\mathrm{p}$ [adre] prior los abonará desde luego la misma cantidad $\mathrm{q}[\mathrm{u}] \mathrm{e}$ se les cargare y él se descargará de ella con la expresión de $\mathrm{q}[\mathrm{u}] \mathrm{e}$ se abona la tal cantidad de zenteno para hazerles asy nada gravosa la paga de su arriendo.

16.- Otrosy, y porq[u]e cediendo a las imperiosas circunstancias de los tiempos, hemos venido en alargar al sacerdote secular, $\mathrm{q}[\mathrm{u}] \mathrm{e}$ con nombram[ien] to de este priorato ejerze el ministerio de vicario nutual en $\mathrm{n}$ [uest]ra feligresía de Pereira, todos los diezmos de ella, se previene a los $\mathrm{p}$ [adre]s priores $\mathrm{q}[\mathrm{u}] \mathrm{e}$ la pensión debida al s[ñn]or deán de Lugo por los frutos de $\mathrm{d}$ [ic]ha vicaría y afecta a ellos se debe pagar, y paga por el mismo vicario $\mathrm{q}[\mathrm{u}] \mathrm{e}$ tiene hecho en esta razón allanamiento judicial ante $\mathrm{d}[\mathrm{ic}] \mathrm{ho}$ $\mathrm{s}$ [eñ]or deán, $\mathrm{p}$ [adre] prior actual y otras personas. Se previenen igualm[en]te $\mathrm{q}[\mathrm{u}] \mathrm{e}$ pagando, como paga, este priorato el subsidio

80 En el Trienio Liberal se habían vendido a dos particulares el monasterio junto con las casas y huertas de las iglesias de Santiago da Riva y Camporramiro; de ahí que con posterioridad el archivo estuviese desordenado. 
correspond[ien]te al total de sus rentas y frutos, en cuyo globo se incluien los diezmos de Pereira, se debe continuar cobrando de d[ic]ho vicario la parte de subsidio correspondiente a los diezmos $\mathrm{q}[\mathrm{u}] \mathrm{e}$ lleva $\mathrm{p}[\mathrm{ar}] \mathrm{a}$ indemnizar asy a este priorato de lo $\mathrm{q}[\mathrm{u}] \mathrm{e}$ paga en el todo de la contribución correspond[ien]te a los frutos de Pereira.

17.- Otrosy, mandamos al $\mathrm{p}[$ adre $]$ prior $\mathrm{q}[\mathrm{u}] \mathrm{e}$ en las partidas de data de zenteno, trigo y vino sólo se descargue con arreglo a lo q[u]e, seg[ú]n las visitas anteriores y Libro de Cuentas, le han señalado mis antezesores. Y por cuanto los curas de Campo Ramiro y Santiago da Riva en lugar de la congrua señalada en la visita de 1806 siguen perciviendo todos los diezmos y emulumentos de sus respectivos curatos, hasta $\mathrm{q}[\mathrm{u}]$ e por nos o $\mathrm{n}[\mathrm{u} e \mathrm{et}$ ] $\mathrm{ros}$ suzesores se determine lo $\mathrm{q}[\mathrm{u}] \mathrm{e}$ parezca más conven[ien]te en el asunto, queda al cuidado de $\mathrm{d}[\mathrm{ic}]$ hos $\mathrm{p}$ [adre]s curas la obligación de stisfazer todas las cargas y pensiones anexas a $\mathrm{d}[\mathrm{ic}]$ hos curatos inclusa la del subsidio de dar linmosna a los pobres de su parroquia y la de contribuir a este priorato el p[adre] cura de Santiago da Riva con quinze canados de vino y el de Campo Ramiro $<$ con $>$ cinco canados, los cuales cañados llevará el $\mathrm{p}$ [adre] prior al Libro de Bodega y se hará cargo de ellos.

18.- Otrosy, hallándose, como se halla, el muro doble de dehesa $\mathrm{q}[\mathrm{u}] \mathrm{e}$ llaman Coto dos Merlos para uso privativo de este monasterio en su leña y en los demás esquilmos, mandamos al $\mathrm{p}$ [adre] prior continue promoviendo todas las mejoras de $\mathrm{q}[\mathrm{u}] \mathrm{e}$ sea susceptible y que por ningún acontecimiento permítase introduzca en ella ganado alguno y asy, en esta como en la del Barazal, se prohibe estrecham[en]te el cortar por el pié los robles $\mathrm{q}[\mathrm{u}] \mathrm{e}$ aún pudieran dar fruto.

19.- Otrosy, en atención a q[u]e asy el ynventario de alajas y ornamentos de la yglesia y sacristía, como los gastos ordinarios y extraordinarios $\mathrm{q}[\mathrm{u}] \mathrm{e}$ se hazen en ella, parezen corresponder al Libro de Misas, como a su proprio lugar, encargamos al $\mathrm{p}$ [adre] prior $\mathrm{q}[\mathrm{u}] \mathrm{e}$ es $\mathrm{y}$ en adel[an]te fuere, ponga en $\mathrm{d}[\mathrm{ic}]$ ho libro los renglones relativos a yglesia y sacristía, en los mismos términos $\mathrm{q}[\mathrm{u}] \mathrm{e}$ hasta aora.

$Y$ finalm[en]te para $\mathrm{q}[\mathrm{u}] \mathrm{e}$ esta visita $\mathrm{n}[\mathrm{ues}-$ t]ra tenga el debido cumplim[ien]to nombramos por zeladores de ella alos dos monjes conventuales más antiguos quienes, si vieren, no se cumple, deberán amonestar al $\mathrm{p}$ [adre] prior y no bastando nos darán aviso para providenciar lo conveniente.

Fue leída esta $\mathrm{n}$ [uest]ra visita en presencia de $\mathrm{p}$ [adre] prior y demás monges de este priorato de San Salvador de Asma, el día veinte de agosto, de mil ochocientos veinte y nueve.

Fr[ay] Pedro Garza, ab[a]d de S[a]n Ben[i]to el R[ea]l.

Por mandado de S[u] P[aternidad] M[uy] $\mathrm{R}$ [everen]da, fr[ay] Pedro Garza, S[ecreta]rio.

\subsection{Visita en agosto de 1833}

Nós, el m[aestro] fr[ay] Rafael Vázquez, m[aest]ro g[ene]ral y abad de de S[an] Ben[i]to el $\mathrm{R}$ [ea]l de Valladoli, sus filiaciones, prioratos $\mathrm{y}$ anejos etc.

Habiendo visitado este priorato monasterial y su yglesia de S[an] Salvador de Asma etc. Y vista la decencia con q[u]e está el S[antísi]mo Sacramento, sagrados oleos y pila baptismal lo $\mathrm{q}[\mathrm{u}] \mathrm{e}$ no $<\mathrm{s}>$ pareció mandar para mayor serbicio de Dios nuestro Señor y aum[en]to temporal y espiritual de esta casa, habiéndolo consultado con el $\mathrm{p}$ [adr]e prior, es lo siguiente:

1.- Primeramente encargamos la conciencia al $\mathrm{p}[\mathrm{adr}] \mathrm{e}$ prior sobre $\mathrm{q}[\mathrm{u}] \mathrm{e}$ guarde $\mathrm{y}$ haga guardar los mandamientos de la ley de Dios y de la Santa Madre Yglesia, la Regla de nuestro $\mathrm{p}$ [adr]e San Benito, Constituciones, Ceremonias y loables costumbres de nuestra sagrada religión, cuanto sea compatible con los respectivos empleos y ocupaciones fuera del claustro y las particulares de este priorato, con lo disp[ues] to en sus visitas y especialm[en]te lo $\mathrm{q}[\mathrm{u}] \mathrm{e}$ se ordena y manda en la presente.

2.- Otrosí, mandamos continúe la loable costumbre de cantar todos los días la salve y la misa los días principales, como también, cuando buenam[en]te se pudiere, se rece en el coro el oficio divino.

3.- Otrosí, encargamos al $\mathrm{p}[\mathrm{adr}] \mathrm{e}$ prior $\mathrm{y}$ a los $\mathrm{p}$ [adre]s curas la mayor limpieza y decencia de sus yglesias teniendo encendida continuam[en]te una lámpara delante del S[antísi]mo Sacramento destinando para el gasto de la azeite las limosnas $\mathrm{q}[\mathrm{u}] \mathrm{e}$ se reciban o fundaciones, si las hubiere. Y, en atención a $\mathrm{q}[\mathrm{u}] \mathrm{e}$ por las circunstancias de los tiempos han percivido en estos años los $\mathrm{p}$ [adre]s curas de Santiago de Arriba y de Campo Ramiro todos los diezmos y emolum[en]tos de sus respectivos curatos en lugar de la congrua $\mathrm{q}[\mathrm{u}] \mathrm{e}$ les está señalada, queda a su cargo y obligac[ió]n 
(con la $\mathrm{q}[\mathrm{u}] \mathrm{e}$ estrecham[en]te reconvenimos) suplir lo $\mathrm{q}[\mathrm{u}] \mathrm{e}$ falte $\mathrm{y}$ sea necesario $\mathrm{p}[\mathrm{ar}] \mathrm{a}$ una luz contínua en todo el año delante del $\mathrm{S}$ [antísi]mo Sacramento, $\mathrm{q}[\mathrm{u}] \mathrm{e}$ el $\mathrm{p}$ [adre] prior tenga obligac[ió]n de darles las dos arrobas ${ }^{80}$ de azeyte, que a cada luno/ se daba, hasta tanto $\mathrm{q}[\mathrm{u}] \mathrm{e}$ se determine otra cosa a cerca de su congrua. Y así mismo reconvenimos al $\mathrm{p}[\mathrm{adr}] \mathrm{e}$ prior y $\mathrm{p}$ [adre]s curas con la precisa obligación de procurar $\mathrm{q}[\mathrm{u}] \mathrm{e}$ todos los feligreses vivan en el santo temor de Dios y estén instruidos en la doctrina cristiana a cuio efecto les encargamos $\mathrm{q}[\mathrm{u}] \mathrm{e}$, todos los días festivos a la misa mayor, les espliquen algún punto de ella y el evangelio en estilo sencillo y acomodado a la inteligencia de los oyentes, exhortándolos a la práctica de las virtudes y detestación de los vicios. Y además los prevenimos $\mathrm{q}[\mathrm{u}] \mathrm{e}$ anoten con toda puntualidad y en la mejor forma (cual lo pide la materia) en los respectivos libros las partidas de los baptizados, confirmados, casados y difuntos remiténdonos previam[en]te cada año certificación jurada de haberlo ejecutado así y de no haber omitido partida alguna; igualmente procuren el más exacto cumplim[ien]to de los testam[en]tos y fundaciones piadosas desempeñando fielm[en]te la obligación de aplicar la misa pro populo todos los días festivos y cada mes otras dos, $\mathrm{q}[\mathrm{u}] \mathrm{e}$ aplicarán cada uno de los tres curas, por las obligaciones de $\mathrm{n}$ [ues] tro monasterio de Valladolid quedando al cargo el $\mathrm{p}$ [adre] prior la aplicación de todas las misas y fundaciones perpétuas $\mathrm{q}[\mathrm{u}] \mathrm{e}$ tiene de obligación este priorato.

4.- Otrosí, por ser esenciales de n[ues]tro instituto los votos de clausura y pobreza, $\mathrm{p}$ [ar] $\mathrm{a}$ su más puntual observancia, mandamos a los monges conv[entuale]s de este priorato $\mathrm{q}[\mathrm{u}] \mathrm{e}$, en cumplimiento de las Constituciones q[ue] de esto tratan y siguiendo en todo su tenor, no salgan sin licencia del $\mathrm{p}$ [adre] prior de la clausura señalada en la visita de 1816 y confirmada en las visitas posteriores, ni los $\mathrm{p}$ [adre]s curas pernocten fuera de sus parroquias no ofreciendo alguna urgencia o negocio particular de sus parroquias o de este priorato. Así mismo mandamos se continue con el depósito común donde los particulares no puedan sacar cantidad alguna, recibir ni gastar sin licencia espresa conforme a ley. Y se previene seria y estrechamente al $\mathrm{p}[\mathrm{adr}] \mathrm{e}$ prior, en lo perteneciente a su persona, como a las licencias que a $\mathrm{n}[\mathrm{omb}] \mathrm{re}$ nuestro diere a los monges conven[tuale]s de este priorato, $\mathrm{q}[\mathrm{u}] \mathrm{e}$ no se crean por manera alguna con facultades para gastos estahordinarios, así en el modo, como en la sustancia y comprando o haciéndose con alajas o cosas notablem[en]te costosas y menos necesarias, como tampoco $\mathrm{p}$ [ar]a regalar y hacer espresiones, aunq[u]e sea a los monges de la Congregación $\mathrm{q}[\mathrm{u}] \mathrm{e}$ no sean muy moderadas.

5.- Otrosí, $\mathrm{p}[\mathrm{ar}] \mathrm{a}$ precaver los graves perjuicios $\mathrm{q}[\mathrm{u}] \mathrm{e}$ se han esperimentado en los enpréstitos $\mathrm{q}[\mathrm{u}] \mathrm{e}$ hasta aquí se hicieron, mandamos al $\mathrm{p}$ [adr]e prior y monges conv[entuale]s no presten cantidad $\operatorname{alg}[\mathrm{un}] \mathrm{a} \mathrm{q}[\mathrm{u}] \mathrm{e}$ pase de sesenta $\mathrm{r}$ [eale]s sin recibir prenda cuio valor esceda por lo menos a una tercera parte al total del empréstito. Ygualm[en]te les prohivimos reciban y retengan en su poder $\mathrm{p}[\mathrm{o}] \mathrm{r}$ vía de depósito cantidades algunas $u$ otros vien $[\mathrm{e}] \mathrm{s}$ pertenecientes a personas seculares, aunq[u]e sean criados de la religión o actuales sirbientes del priorato; respecto de los cuales encargamos muy estrecham[en]te al $\mathrm{p}[\mathrm{adr}] \mathrm{e}$ prior, sobre $\mathrm{q}[\mathrm{u}] \mathrm{e}$ le gravamos la conciencia, y respectivam[en]te a los $\mathrm{p}$ [adres] curas de Santiago da Arriba y Campo Ramiro por lo pertenec[ien]te a los suyos el cuidado de apuntar con toda claridad y precisión en su Libro de Caxa la soldada y condiciones en $\mathrm{q}[\mathrm{u}] \mathrm{e}$ los tiene ajustados y de habérseles satisfecho, como lo deben hacer siempre al fin de cada año esponiéndolo así en los Memoriales q[u]e en las visitas deben presentarnos ${ }^{81}$.

6.- Otrosí, mandamos al $\mathrm{p}[$ adre $]$ prior $\mathrm{q}[\mathrm{u}] \mathrm{e}$ todos los años por San Juan de junio tome y estienda las cuentas en los respectivos libros cuia copia remita a $n$ [ues]tro mon[asteri]o de Valladolid para trasladarlas al Libro de Prioratos, y en el año de capítulo practique la misma diligencia antes de Pascua de Resurecc[ió]n, espresando con toda individualidad a continuac[ió]n, así de las cuentas del Libro de Depósito como en las $\mathrm{q}[\mathrm{u}] \mathrm{e}$ se remitan a Valladolid, el estado en que queda el priorato en aprovecham[ien]tos, prorrateos, pleitos, gastos y demás $\mathrm{q}[\mathrm{u}]$ e ocurra en la misma forma $\mathrm{q}[\mathrm{u}] \mathrm{e}$

80 Usa el signo clásico @ para expresar la arroba. La arroba de aceite, más o menos, eran unos doce litros y medio. El documento
más antiguo donde se usa este símbolo es la Taula de Ariza (Archivo Provincial de Zaragoza, a. 1448). 81 Escribe "presentarlos", pero sobreescribe "presentarnos". 
se estiende en los monasterios. Y cuando entre nuevo prior entre éste y el $\mathrm{q}[\mathrm{u}] \mathrm{e}$ concluie se formen cuentas finales y se haga formal entrega de todas las alaxas y ajuares propios de esta casa, las $\mathrm{q}[\mathrm{u}] \mathrm{e}$ firmen uno y otro en su Libro Inventario, quedando obligado el $\mathrm{q}[\mathrm{u}] \mathrm{e}$ sale a dejar serbibles y usuales las alajas y axuares $\mathrm{q}[\mathrm{u}] \mathrm{e}$ recibió. Así mismo mandamos al p[adre] prior cubra las contrapartidas de los encabezados en los respectivos libros y apuntar en expresión de cada año las partidas $\mathrm{q}[\mathrm{u}] \mathrm{e}$ se hayan cobrado y en adelante se cobraren, so pena de incurrir en la pena de privac[ió]n de oficio y las $\mathrm{q}[\mathrm{u}]$ e según ley deben aplicarse de omisión tan grave y perjudicial, y además mandamos $\mathrm{q}[\mathrm{u}] \mathrm{e}$ $\mathrm{s}$ [i]empre que se forme nuebo encazado de rentas, $\mathrm{q}[\mathrm{u}] \mathrm{e}$ deberá ser por lo menos una vez al quatrienio, se remita copia literal a $\mathrm{d}[\mathrm{ic}] \mathrm{ho}$ n[ues]tro mon[asteri]o de Valladolid.

7.- Otrosí, por cuanto a más del beneficio $\mathrm{q}[\mathrm{u}] \mathrm{e}$ resulta de laudemios es muy conducente a la mayor seguridad de las haciendas y facilidad de la cobranza de rentas, mandamos al $\mathrm{p}$ [adr]e prior averigüe con la posible solicitud las ventas q[u]e se hicieren de los vienes aforados y procure $\mathrm{q}[\mathrm{u}] \mathrm{e}$ los nuevos poseedores reconozcan el directo dominio y paguen el laudemio conforme a lo estipulado en la es[critur]a de foro.

8.- Otrosí, para precaver en lo sucesivo los enormes perjuicios $\mathrm{q}[\mathrm{u}]$ e resultan de la dilación en la cobranza de rentas, mandamos al $\mathrm{p}$ [adr]e prior continue en las diligencias relativas a la cobranza de atrasos e igualm[en]te en hacer efectivas todas las correspondientes al tiempo de su administrac[ci]ón, bien entendido $\mathrm{q}[\mathrm{u}] \mathrm{e}$ en las cuentas finales no se le admitirá en descargo partida alguna abierta si $\backslash \mathrm{n} / \mathrm{q}[\mathrm{u}] \mathrm{e}$ haga constar $\mathrm{q}[\mathrm{u}] \mathrm{e}$ practicó las diligencias judiciales y necesarias $\mathrm{p}$ [ar]a su cobranza dirigiéndolas (siempre $\mathrm{q}[\mathrm{u}] \mathrm{e}$ haya lugar) contra los principales foreros y más avonados llevadores. Se le permite no obstante haga algunas prudentes condonaciones a los colonos indigentes $\mathrm{q}[\mathrm{u}] \mathrm{e}$ por pobreza y verdadera necesidad hayan diferido o no cumplido las pagas ${ }^{82}$ llevando al Libro de Depósito ${ }^{83}$ las cantidades causadas a $\mathrm{d}[\mathrm{ic}]$ has cobranzas con espresión de los valores corrientes en los años a q[u]e corresponden las deudas.
9.- Otrosí mandamos al $\mathrm{p}[$ adre $]$ prior averigüecon toda diligencia las porciones de terreno $\mathrm{q}[\mathrm{u}] \mathrm{e}$ se roturan y cultivan en el monte de $\mathrm{S}[\mathrm{a}] \mathrm{n}$ Sebastián y más terrenos propios de este prioroato $\mathrm{q}[\mathrm{u}] \mathrm{e}$ no están aforados y cobre de todos los frutos $\mathrm{q}[\mathrm{u}] \mathrm{e}$ en ellos se causaren además del diezmo un quinto íntegro por razón del directo dominio cuias partidas anote y tome len/ cargo en los libros a correspondan. Así mismo le mandamos continúe en el cuidado de proseguir la importante obra de los prorrateos $\mathrm{p}$ [ar]a aclarar por este medio las rentas oscurecidas y no dar lugar a que otras se oscurezcan.

10.- Otrosí, reconvenimos al $\mathrm{p}$ [adr]e prior y los tres $\mathrm{p}$ [adre]s curas con lo que ordenan y disponen n[ues] tras Constituciones sobre el abuso de tener en sus casas cantidades escesivas de dineroy les mandamos $\mathrm{q}[\mathrm{u}] \mathrm{e}$, además de las cantidades necesarias para los gastos ordinarios, no tengan en su poder otras cantidades por más tiempo q[u]e el de quince días en los que deberá el $\mathrm{p}$ [adr] e prior buscar con toda diligencia medio de remitirlas a $\mathrm{n}$ [ues]tro mon[asteri]o de Valladolid y no proporcionándose este medio lo habrá de poner interinam[en]te en el depósito de nues]tro monasterio de San Vic[en]te de Monforte, lo mismo q[u]e practicarán los tres $\mathrm{p}$ [adre] $\mathrm{s}$ curas con sus peculios respectivos. Así mismo, con el objeto de moderar en lo posible los escesivos gastos de este priorato, renovando las acertadas providencias dadas a este efecto, mandamos al p[adr]e prior $\mathrm{q}[\mathrm{u}] \mathrm{e}$ sólo mantenga los criados y bestias absolutam[en]te indispensables para el servicio de esta casa y condución de rentas $\mathrm{q}[\mathrm{u}] \mathrm{e}$ está a su cargo y no al de los foreros, conforme a la condición de las es[critu]ras forales; para cuya mayor espedición mandamos se continúe con el arriendo de los diezmos mayores y menores como hasta aquí, en estos y otros tales conventos, se estipule espresam[en]te $\mathrm{q}[\mathrm{u}] \mathrm{e}$ los llevadores costeen la copia de la es[critu]ra original $\mathrm{q}[\mathrm{u}] \mathrm{e}$ se pondrá en el archivo, y por lo que hace a los ferrados de castañas, atendiendo a su menor percivo, originado de la corta de varios castaños con motivo de la obra de la/ casa y se pasan por ahora y se dejan (como hasta aquí la paja) para \las/necesidades y consumo del priorato. 
11.- Otrosí, reconvenimos al $\mathrm{p}[\mathrm{adr}] \mathrm{e}$ prior con lo que disponen n[ues]tras leyes cap[ítulo] $24, \mathrm{lib}[\mathrm{ro}] 2^{\circ}$, sobre que no saque papel alguno del archivo sin dejar escrito en un quaderno, $\mathrm{q}[\mathrm{u}] \mathrm{e} \mathrm{p}[\mathrm{ar}] \mathrm{a}$ el fin tendrá en el mismo archivo, el instrum[en]to q[u]e sacó, el día mes y año para que sin permittir (sic) a persona alguna entrar ni estar en el archivo sin hallarse el mismo presente; y le encargamos estrecham[en]te continue poiendo los \papeles/ en or[de]n y con aseo poniendo en los legajos los ynstrum[en]tos y papeles sueltos $\mathrm{q}[\mathrm{u}] \mathrm{e}$ puedan encuadernarse haciéndolos forrar $\mathrm{p}$ [ar]a su mayor duración practicando igual diligencia con los ya encuadernados, si lo necesitaren. Del mismo modo se recomienda el cuidado de anotar en un Libro de Apuntaciones todas las advertencias que juzgue conveniente para el gobierno de este priorato con la laudable idea de mejorar en lo posible el estado de este priorato como $\mathrm{q}[\mathrm{u}] \mathrm{e}$ está librado unicam[en]te en los papeles de su archivoy en el buen manejo y uso de ellos.

12.- Otrosí, renovamos el mandato impuesto a los $\mathrm{p}[\mathrm{adre}] \mathrm{s}$ priores $\mathrm{p}[\mathrm{ar}] \mathrm{a} \mathrm{q}[\mathrm{u}] \mathrm{e}$ no se hagan partes personales y principales dueños en los contratos, diligencias, judiciales, provisiones de piezas ec[lesiásti]cas y otros empleos de justicia, sino $\mathrm{q}[\mathrm{u}] \mathrm{e}$ en todo esto se arreglen puntualem[en]te a lo dispuesto en el cap[ítulo] 23 de n[ues]tras Constituciones y den siempre por parte principal al $\mathrm{p}$ [adre] abad y monasterio de Valladolid en quien reside todo el dominio de este priorato sin esceder por manera alguna al poder, instrucción y órdenes $\mathrm{q}[\mathrm{u}] \mathrm{e}$ se le hubieren dado y se le dieren en los lances particulares $\mathrm{q}[\mathrm{u}] \mathrm{e}$ ocurran y deberan consultar.

13.- Otrosí, por cuanto al presente los $\mathrm{p}$ [adre]s curas de Campo Ramiro y Santiago de Arriba residen en sus respectivas filigresías les mandamos $\mathrm{q}[\mathrm{u}] \mathrm{e}$ asistan continuam[en]te en ellas sin que puedan pernoctar fuera sin licencia del $\mathrm{p}$ [adr]e prior de este priorato como individuos y conventuales $\mathrm{q}[\mathrm{u}] \mathrm{e}$ son d'el; y el $\mathrm{p}$ [adr]e prior a quien facultamos para darla de tres o quatro días a distancia de tres o cuatro leguas se arreglará a lo $\mathrm{q}[\mathrm{u}] \mathrm{e}$ disponen $\mathrm{n}$ [ues]tras leyes en el particular y a la práctica común y autorizada de n[ues]tro monast[eri]o.

14.- Otrosí para ocurrir a los inconvenientes $\mathrm{q}[\mathrm{u}] \mathrm{e}$ pueden sobrevenir en lo sucesivo a cerca de la libertad y entero dominio de este priorato, asi en las casas como en los huertos $\mathrm{q}[\mathrm{u}] \mathrm{e}$ se han hecho y comprado por este priorato (como todo consta de las escrituras y papeles feeacientes y en las $\mathrm{q}[\mathrm{u}] \mathrm{e}$ viven y disfrutan respectivam[en] te dichos $p$ [adres] curas de Campo Ramiro y Santiago de Arriba encargamos extrecham[en]te al $\mathrm{p}$ [adre] prior $\mathrm{q}[\mathrm{u}] \mathrm{e}$ pase al archivo y guarde el papel de obligac[ió]n formal y autorizado en cuia vuirtud y poniendo por cabeza la razón \de la/ respectiva individual pertenencia de $\mathrm{d}[\mathrm{ic}]$ has fincas cada uno de $\mathrm{d}[\mathrm{ic}]$ hos [adres] curas se obligue a pagar con separc[ió]n por casa casa y huerto la cantidad anual de centeno en $\mathrm{q}[\mathrm{u}] \mathrm{e}$ a juicio de perito inteligente se declare poder estimarse en un arriendo equitativo las sobre $\mathrm{d}[\mathrm{ic}]$ has fincas $\mathrm{y}$ el $\mathrm{p}$ [adre] prior la tomará en cargo en su libro de centeno. Mas para que esta providencia no pare perjuicio a $\mathrm{d}[\mathrm{ic}]$ hos $\mathrm{p}$ [adre]s curas el $\mathrm{p}$ [adre] prior las avonará desde luego la misma cantidad que se les cargase y el se descargará de ella con la expresión de $\mathrm{q}[\mathrm{u}] \mathrm{e}$ se avona la tal cantidad de centeno para hacerles así nada gravosa la paga de su arriendo.

15.- Otrosí, por $\mathrm{q}[\mathrm{u}] \mathrm{e}$ cediendo a las imperiosas circunstancias de los tiempos hemos venido en alargar al sacerdote secular, que con nombram[ien] to de este priorato exerce el ministerio de vicario nutual en $n[$ ues]tra feligresía de Pereira, todos los diezmos de ella, se previene a los $\mathrm{p}[$ adre] $\mathrm{s}$ priores $\mathrm{q}[\mathrm{u}] \mathrm{e}$ la pensión debida al debida a $1 \mathrm{~s}[$ eñ] or deán de Lugo por los frutos de $\mathrm{d}[\mathrm{ic}]$ havicaría y afecta a ellos se debe pagar y paga por el mismo vicario $\mathrm{q}[\mathrm{u}] \mathrm{e}$ tiene hecho en esta sazón allanam[ien]to judicial lante el s[eñ]or deán/, $\mathrm{p}[\mathrm{adr}] \mathrm{e}$ prior y otras personas se previene igualm[en]te $\mathrm{q}[\mathrm{u}] \mathrm{e}$ pagando. Como paga, este priorato el subsidio correspondiente al total de sus rentas y frutos en cuio glovo se incluien los diezmos de Pereira se debe continuar cobrando de $\mathrm{d}[\mathrm{ic}] \mathrm{ho}$ vicario la parte de subsidio correspondiente a los diezmos $\mathrm{q}[\mathrm{u}] \mathrm{e}$ lleva $\mathrm{p}[\mathrm{ar}] \mathrm{a}$ indenizar a este priorato de la dela que paga del todo de la contribuc[i]ón correspond[ien]te a los frutos de Pereira.

16.- Otrosí, mandamos al $\mathrm{p}$ [adre $]$ prior $\mathrm{q}[\mathrm{u}] \mathrm{e}$ en las partidas de data de centeno trigo y vino sólo se descargue con arreglo a los $\mathrm{q}[\mathrm{u}] \mathrm{e}$ en las visitas anteriores y libros de las cuentas le han señalado $\mathrm{n}$ [ues] tros antecesores y por cuanto los curas de Campo Ramiro y Santiago da Riva en lugar de la congrua señalada en la visita de 1806 siguen perciviendo todos los diezmos y emolum[en]tos de sus respectivos curatos hasta $\mathrm{q}[\mathrm{u}] \mathrm{e}$ por nos, o nuestro sucesores, se determine lo $\mathrm{q}[\mathrm{u}] \mathrm{e}$ parezca más conven[ien]te en 
el asunto y queda al cuidado de los $\mathrm{d}[\mathrm{ic}]$ hos $\mathrm{p}$ [adre]s curas la obligac[ió]n de satisfacer todas las cargas y pensiones anejas a d[ic]hos curatos inclusa la del subsidio, la de dar limosna a los pobres de sus parroquias y la de contribuir a este priorato el $\mathrm{p}$ [adre] cura de Campo Ramiro con cinco $<$ canados $>$, los cuales cañados llevará el $\mathrm{p}$ [adr]e prior al Libro de Bodega y se hará cargo de ello.

17.- Otrosí, hallandose, como se halla, con muro doble la dehesa q[u]e llaman Coto de Merlos $^{84}$ para uso privativo de este priorato en su leña y demás esquilmos es igualm[en]te cercada y guardada la llamada del Barazal, mandamos al $\mathrm{p}$ [adr]e prior continue plantando robles y otros árboles y promoviendo en ellos todas las mejoras de $\mathrm{q}[\mathrm{u}] \mathrm{e}$ sean susceptibles, a este efecto no permita entrar ganados $\mathrm{u}$ otros animales $\mathrm{q}[\mathrm{u}] \mathrm{e}$ perjudiquen a la cría, acrecentam[ien]to y arraigo de d[ic] hos árboles y para evitar en lo sucesivo los graves daños y perjuicios que se han seguido de cortar árboles por el pié escaseando por este motivo sobremanera la leña de $\mathrm{q}[\mathrm{u}] \mathrm{e}$ tanto necesita este priorato, se prohive $\mathrm{d}[\mathrm{ic}]$ ha corta por el pié como igualm[en]te el cortar fuera e tiempo y sin sazón la q[u]e no está bien hecha arreglando en adelante y separando las cortas por años solamente de la $\mathrm{q}[\mathrm{u}] \mathrm{e}$ sea necesaria $\mathrm{p}$ [ar]a el gasto del priorato sin permitir por más abundancia $\mathrm{q}[\mathrm{u}] \mathrm{e}$ haya en lo sucesivo y vender, dar o regalar leña alguna de lo que se le hará cargo y será responsable en la visita $\mathrm{d}[\mathrm{ic}]$ ho $\mathrm{p}$ [adre] prior, también se previene $\mathrm{y}$ encarga estrecham[en]te a los $\mathrm{p}$ [adre]s priores no permitan cortar o estrabiar el agua $\mathrm{q}[\mathrm{u}] \mathrm{e}$ viene del manantial del Recobio ${ }^{85}$ a la huerta y prados del priorato dejando a los vecinos aprovecharse de ella para riego de prados, linos, etc. No siendo con su licencia $\mathrm{p}[\mathrm{ar}] \mathrm{a}$ alguna necesidad a fin de conservar el derecho y posesión en $\mathrm{q}[\mathrm{u}] \mathrm{e}$ se halla este priorato de tiempo inmemorial y evitar contestaciones y recursos judiciales a los $\mathrm{q}[\mathrm{u}] \mathrm{e}$ usó antes de ahora $\mathrm{p}[\mathrm{ar}] \mathrm{a}$ su conservación ${ }^{86}$.

18.- Otrosí, en atención a $\mathrm{q}[\mathrm{u}] \mathrm{e}$ así el inventario de alajas y ornamentos de la yglesia y sacristía, como los gastos ordinarios y extraordinarios $\mathrm{q}[\mathrm{u}] \mathrm{e}$ en ella se hacen parecen corresponder al Libro de Misas como a sus propio lugar, encargamos al $\mathrm{p}[\mathrm{adr}] \mathrm{e}$ prior ponga en $\mathrm{d}[\mathrm{ic}]$ ho libro los renglones relativos a yglesia y sacristía en los mismos términos $\mathrm{q}[\mathrm{u}] \mathrm{e}$ hasta ahora.

$\mathrm{Y}$ finalmente para $\mathrm{q}[\mathrm{u}] \mathrm{e}$ esta nuestra visita tenga el debido cumplimiento nombramos por celadores a de ella a los dos monjes conventuales más antiguos, quienes, si vieren q[u]e no se cumple, deveran amonestar al $\mathrm{p}$ [adre] prior y si esto no fuere suficiente nos darán aviso $\mathrm{p}[\mathrm{ar}] \mathrm{a}$ providenciar lo conven[ien]te.

Fue leída esta nuestra visita en presencia del $\mathrm{p}$ [adr]e prior y demás monjes en este priorato de San Salvador de Asma, a 10 de septiembre de 1833.

Fr[ay] Rafael Vázquez, abad de S[a]n Benito el R[ea].

Por mandado de S[u] P[aternidad] M[uy] $\mathrm{R}$ [everen]da, fr[ay] Antonio Villa.

\section{Colofón}

Hasta aquí las visitas de los últimos años del monasterio de San Salvador de Chantada. Ellas nos dejan entrever la dificultades históricas del momento, la presión del monasterio de Valladolid sobre sus prioratos y, desde estos, el exigente control que se ejercía sobre los colonos en el pago de diezmos y otras rentas. Igualmente se vislumbran algunas dificultades que tiene el priorato como la escasez de leña por la tala de árboles hecha para obras anteriores de las que tenemos documentación, como por ejemplo el arreglo del puertas, la "solaina", la parte alta del claustro o el molino. Otro de los problemas que dejan ver las visitas son los gastos, excesivos según las distintas visitas,

84 Esta finca está al lado del monasterio y se extiende hasta cerca del actual lugar de Vilanova do Monte. Por dicha finca se conducía el agua para el monasterio y para el molino que estaba al lado de dicha casa de la que tenemos documentación moderna y año de su construcción.

85 Llevan el nombre de "Recobio" los montes y prados que están más abajo de la actual entrada al polígono industrial chantadino de los Acibros. Actualmente están entre la carretera de circunvalación y el tramo antiguo de la carretera 540. Es zona de manantiales y recogida del agua que baja de Vilanova do Monte. Tengase en cuenta que el agua es esencial en la vida de cualquier monasterio. Por eso una de las cuestiones que indica la regla de San Benito es que el monasterio ha de estar cerca de fuentes de agua y lugares de cultivo para la subsistencia de la vida del monasterio (cf. La regla de San Benito, 1993: 180-181).

85 Consta en la documentación que por el agua de la que se habla aquí hubo pleito con los vecinos del lugar de Quintela. 
contra lo cual se exigía un pormenorizado control, incluso cuando se trateba de un pequeño regalo a monjes de la orden por mostrar agradecimiento o "hacer expresión".

En definitiva, son estas visitas un material rico, a la par de otras fuentes conservadas, para estudiar las circunstancias problemáticas de los últimos días de la vida del monasterio de Chantada hasta la definitiva exclaustración en 1836 debido al incumplimiento de las exigencias de los decretos desamortizadores de Mendizábal.

\section{Referencias bibliográficas}

Álvarez Gómez, Jesús (1989): Historia de la vida religiosa. Madrid: Publicaciones Claretianas.

Álvarez Palenzuela, Vicente Ángel (1982): El Cisma de Occidente. Madrid: Rialp.

Amasuno Sarraga, Marcelino V. (1996): La peste en la Corona de Castilla durante la segunda mitad del siglo XIV. Salamanca: Junta de Castilla y León.

Amran, Rica (1996): "Judios y conversos en las crónicas de los Reyes de Castilla (desde finales del siglo XIV hasta la expulsión)", Espacio, Tiempo y Forma (Historia Medieval, Serie III) 9, pp. 257-275.

— (2003): De judios a judeo conversos. Reflexiones sobre el ser converso. Paris: Índigo / Université de Picardie.

Ares Vázquez, Nicandro (2013): Estudos de toponimia galega. A Coruña: Real Academia Galega.

Ariès, Philippe (1982): La muerte en Occidente. Barcelona: Argos Vergara.

Baró i Queralt, Xavier y José Antonio Ontalba y Ruipérez (1999): “Aproximación a la moral en la en la Tarraconense", Hispania Sacra 51, pp. 655-667.

Barros, Carlos (1991): Mentalidad justiciera de los irmandiños, siglo XV. Madrid: Siglo 21.

— (2006): "Lo que sabemos de los irmandiños", Clio y Crimen 3, pp. 36-48.

Beltrán Moya, José Luis (1994): “La peste como problema historiográfico”, Manuscrits: Revista d'història moderna 12, pp. 283-319.

Benedictow, Ole J. (2011): La peste negra, 1346-1353. La historia completa. Madrid: Akal.

Benito Ruano, Eloy (1976): Los origenes del problema converso. Barcelona: Marcial Pons.

Bernáldez, Andrés (1870): Historia de los Reyes Católicos don Fernando y doña Isabel. Sevilla: Imprenta de José María Geofrin [ed. moderna Memorias del reinado de los Reyes Católicos, que escribía el bachiller Andrés Bernáldez, Cura de los Palacios, eds. M. Gómez Moreno y J. de M. Carrizo. Madrid: Real Academia de la Historia / CSIC, 1962].

Berlière, Ursmer (1927): Les Élections abbatiales au Moyen Âge. Bruselas: Hayez.

Bois, Guy (2007): La gran depresión medieval: siglos XIV-XV. El precedente de una crisis sistémica. Valéncia: Universitat.

Bühler, Johannes (1977): Vida y cultura en la Edad Media. México: F.C.E.

Canesi Acevedo, Manuel (1996): Historia secular, y eclesiástica de la muy antigua, augusta, coronada, muy ilustre, muy noble, rica y muy leal ciudad de Valladolid (ed. del Grupo Pinciano). Valladolid: Caja España / Ayuntamiento de Valladolid, Consorcio IV Centenario Ciudad de Valladolid.

Cebrián Franco, Juan José (1997): Obispos de Iria y Arzobispado de Santiago de Compostela. Santiago de Compostela: Instituto Teológico Compostelano.

Colmeiro, Manuel (ed.) (1863): Cortes de los Antiguos Reinos de León y Castilla. Madrid: Imprenta y Estenotipia de M. Rivadeneyra.

Colombas, García M. y Mateo M. Gost (1954): Estudios sobre el primer siglo de san Benito de Valladolid. Monserrat: Administración de Publicaciones.

Constituciones de la Congregación de Nuestro Glorioso Padre San Benito de España e Inglaterra. Madrid: Oficina de la viuda de Melchor Álvarez, 1706.

Delumeou, Jean (2012): El miedo en occidente (siglos XIV-XVIII). Una ciudad sitiada. Madrid: Taurus.

Domenico Mansi, Giovanni (1961): Sacrorum Conciliorum nova et amplissima collectio. Graz (Austria): Akad. Druck- und Verl.-Anst.

Fernández Conde, Francisco Javier (1978): Gutierre de Toledo, obispo de Oviedo (1377-1389): reforma eclesiástica en la Asturias bajomedieval. Oviedo: Universidad.

Fita, Fidel (1893): “Concilios Españoles inéditos”, Boletín de la Real Academia de la Historia 22, pp. 213257.

Fossier, Robert (1983): Le Moyen Age, le tempes des crises, 1250-1520. Paris. 
Framiñán de Miguel, Jesús (2005): "Manuales para el adoctrinamiento de neoconversos en el s. XVI", Criticón 93, pp. 27-27.

Galbán Malagón, Carlos J. (2010): A guerra dos irmandiños (1465-1469). Santiago de Compostela: Lóstrego.

García López, Aurelio (ed.) (2014): Suma de la vida del Cardenal Mendoza, de Francisco de Medina y Mendoza. Guadalajara: Editores del Henares (Colección Temas de Guadalajara 9).

García Oro, José (1969): La reforma de los religiosos españoles en tiempo de los Reyes Católicos. Valladolid: Instituto "Isabel la Católica" de Historia Eclesiástica.

— (1971): Cisneros y la reforma del clro español en tiempo de los Reyes Católicos. Madrid: CSIC / Instituto Jerónimo Zurita.

— (1977): Galicia en la Baja Edad Media. Iglesia, Señorio y nobleza. Santiago de Compostela: El Eco Franciscano.

- (1987): Galicia en los siglos XIV y XV. Madrid: Fundación Pedro Barrié de la Maza.

García Villada, Ricardo (1956): "Rasgos característicos de la devotio moderna", Manresa 28, pp. 315-350.

García Villoslada, Ricardo (1956): "Rasgos caracteristicos de la devotio moderna”, Manresa 28, pp. 315350 .

— (1967): Historia de la Iglesia Católica. Madrid: Biblioteca de Autores Cristianos.

Glatzer, Michael (1995): "Crisis de la fe judía en españa a fines del siglo XIV y principios del XV”, en A. Alcalá Galve (coord.), Judios, sefarditas y conversos. La expulsión de 1492 y sus consecuencias. Ponencias del Congreso internacional celebrado en Nueva York en noviembre de 1992. Valladolid: Ámbito Ediciones, pp. 55-67.

Gonzalez-García Valladolid, Casimiro (1901): Valladolid, sus recuerdos y grandezas. Valladolid: Imp. Juan Rodríguez Hernándo.

Hay, Denys (1980): Europa en los siglos XIV y XV. Madrid: Aguilar.

Huizinga, Johan (1978): El otoño de La Edad Media. Estudios sobre la forma de vida y del espiritu durante los siglos XIV y XV en Francia y en los Países Bajos. Madrid: Alianza Editorial.

Kasper et al. (eds.) (2003): Diccionario enciclopédico de los papas y del papado. Barcelona: Herder Editorial.

- (eds.) (2005a): Diccionario enciclopédico de historia de la Iglesia. Barcelona: Herder Editorial.

— (eds.) (2005b): Diccionario enciclopédico de la época de la Reforma. Barcelona: Herder Editorial.

Kempis, Tomás de (1946): Imitación de Cristo. Barcelona: Regina.

La regla de San Benito (trad. G. M. Colombás, notas I. Aranguren). Madrid: Biblioteca de Autores Cristianos, 1993.

Lawrence, Clifford Hugh (1999): El monacato medieval. Formas de Vida Religiosa en Europa Occidental durante la Edad Media. Madrid: Gredos.

López Ferreiro, Antonio (1905): Historia de la Santa A[postólica] y M[etropolitana] Iglesia de Santiago de Compostela. Santiago de Compostela: Imprenta y Encuadernación del Seminario Conciliar Central.

López Carreira, Anselmo (1991): Os Irmandiños textos, documentos e bibliografía. Vigo: A Nosa Terra.

Martínez Millán, José y Carlos Javier de Carlos Morales (2011): Religión politica y tolerancia en la Europa moderna. Madrid: Ediciones Polifemo.

Maté Sadornil, Lorenzo (2007-08): Actas y constituciones de los Capitulos de la Congregación de San Benito de Valladolid (1497-1610). Silos (Burgos): Abadía de Silos / Rico Adrados.

Méndez Pérez, Xosé (2015): "Documento dun preito polo pagamento de décimos de patacas", Alicerces 1, pp. 193-210.

Méndez Pérez, Xosé, Pablo Otero Piñeiro Maseda y Miguel Romaní Martínez (2016): El monasterio de San Salvador de Chantada (siglos XI-XVI). Historia y Documentos. Madrid: CSIC.

Menéndez Pelayo, Marcelino (1944): Antología de poetas líricos castellanos (ed. E. Sánchez Reyes). Santander: Aldus.

- (1956): Historia de los heterodoxos españoles. Madrid: Biblioteca de Autores Cristianos.

Mitre Fernández, Emilio (1980): Judaísmo y cristianismo. Raíces de un gran conflicto histórico. Madrid: Istmo.

(1990): La guerra de los Cien Años. Madrid: Historia 16.

_- (1993): Los judios de Castilla en tiempos de Enrique III. El progrom de 1391. Valladolid: Universidad, Secretariado de Publicaciones. 
- (2004): Fantasmas de la sociedad medieval: enfermedad, peste, muerte. Valladolid: Universidad, Secretariado de Publicaciones e Intercambio Editorial.

- (2007): Iglesia, herejía y vida política en la Europa medieval. Madrid: Biblioteca de Autores Cristianos. Monsalvo Antón, José María (1985): Teoría y evolución de un conflicto social. El antisemitismo en la corona de Castilla en la baja Edad Media. Madrid: Siglo XXI.

Narbona, Eugenio (1624): Historia de D. Pedro Tenorio arzobispo de Toledo. Dos libros. Toledo: Iuan Ruyz de Pereda.

Nomenclátor de Galicia. Lugo. Santiago de Compostela: Xunta de Galicia, 2000.

Palencia, Alfonso de (1904-08): Décadas o Crónica de Enrique IV. Madrid: Tipografía de la Revista de Archivos (trad. A. Paz y Meliá).

Perroy, Edouard (1982): La guerra de los Cien años. Madrid: Akal.

Pulgar, Fernando del (1936): Epistolario Español. Colección de cartas de españoles ilustres antiguos y modernos, recogida y ordenada con notas y aclaraciones históricas, críticas y geográficas. Madrid: Imprenta Rivadeneyra (Biblioteca de Autores Españoles).

Rodríguez Martínez, Luis (1981): Historia del monasterio de San Benito el Real de Valladolid. Valladolid: Ateneo / Caja de Ahorros Popular.

Rubial García, Antonio. (2001): "Isabel de Castilla y los movimientos religiosos en España durante su reinado. Su impacto en América”, en J. Valdeón Baruque (ed.): Isabel la Católica y la política: poencias presentadas al I Simposio sobre el reinado de Isabel la Católica, celebrado en las ciudades de Valladolid y México en el otoño de 2000. Valladolid: Ámbito Ediciones, pp. 351-362.

Ruiz de Loizaga, Saturnino (2009): La peste en los reinos peninsulares según la documentación del Archivo Vaticano (1348-1460). Bilbao: Museo Vasco de Historia de la Medicina y de la Ciencia.

Sá Bravo, Hipólito de (1972): El monacato en Galicia. A Coruña: Editorial Librigal.

Sánchez Herrero, José (1976): Concilios provinciales y Sínodos Toledanos de los s. XIVy XV. La religiosidad cristiana del clero y pueblo [Sta. Cruz de Tenerife]: Universidad de la Laguna.

Sánchez Sesa, Rafael (1995): "Don Pedro Tenorio y la reforma de las órdenes monásticas en el último tercio del Siglo XIV. La vinculación del prelado a la espiritualidad jerónima”, En la España Medieval 18, pp. 289-302.

Sangrador Minguela, Federico (1904): La iglesia de San Benito el Real de Valladolid. Valladolid.

Sangrador Vitores, Matías (1854): Historia de la muy noble y muy leal ciudad de Valladolid. Valladolid.

Seibt, Ferdinand y Winfried Heberhard (1993): Europa 1400. La crisis de la baja Edad Media. Barcelona: Crítica.

Serrano y Pineda, P. Luciano (1941): Don Pablo de Santa María. Gran rabino y obispo de Burgos. Madrid: Academia de la Historia.

Suárez Fernández, Luis (coord.) (1981): Los Trastámara y la unidad Española (1369-1517), Tomo V (Historia general de España y América). Madrid: Rialp.

- (1982): Historia del reinado de Juan I de Castilla. Madrid: Universidad Autónoma.

Tejada y Ramiro, Juan (1855): Colección de cánones y de todos los concilios de la Iglesia de España y de América. Madrid: Imprenta de D. Pedro Montero.

Tuchman, Barbara Werthein (2000): Un espejo lejano. El calamitoso siglo XIV. Barcelona: Círculo de Lectores.

Vaca Lorenzo, Angel (1990): “La peste negra en Castilla”, Studia Histórica. Historia Medieval 8, pp. 159171.

Valdeón Baruque, Julio (1968): Los judios de Castilla y la revolución Trastámara. Valladolid: Universidad, Secretariado de Publicaciones.

Verger, Jacques $\left(2001^{2}\right)$ : Gentes del saber en la Europa de finales de la Edad Media. Madrid: Editorial Complutense.

Vidal García, Marciano (2011): Historia de la moral. Moral y espiritualidad en la cristiandad medieval (ss. VIII-XIV). Madrid: PS.

Vilches Vivancos, Fernando (1994): El Cardenal Mendoza: datos biográficos definitivos y obra literaria. Guadalajara: Institución Provincial de Cultura Marqués de Santillana.

Villalba Ruiz de Toledo, Francisco Javier (1988): El Cardenal Mendoza (1428-1495). Madrid: Rialp.

— (1999): Colección Diplomática del cardenal Mendoza. Madrid: Universidad Autónoma. 
Yepes, Fr. Antonio de (1621): Coronica General de San Benito Patriarca de Religiosos. Valladolid: por la viuda de Francisco Fernandez de Cordoua (ed. Fr. Justo Pérez de Urbel: Crónica general de la orden de San Benito. Madrid: Biblioteca de Autores Españoles, 2001).

Zaragoza Pascual, Ernesto (1973): Los Generales de la Congregación de San Benito de Valladolid, I . Los Priores. Silos: Monasterio de Silos.

— (1993): "La reforma monástica del monasterio de Santa María de Mezonzo", Compostellanum XXXVIII/3-4, pp. 395-433.

— (2002): "Reforma de los monasteriso de Lobios, Dozón y Ansemil (1498-1499)", Cuadernos de Estudios Gallegos XLIX/115, pp. 81-124. 